\title{
Mental Decrepitude on the U.S. Supreme Court: The Historical Case for a 28th Amendment
}

\author{
David J. Garrow†
}

\section{INTRODUCTION}

Mental decrepitude and incapacity have troubled the United States Supreme Court from the 1790s to the 1990s. The history of the Court is replete with repeated instances of justices casting decisive votes or otherwise participating actively in the Court's work when their colleagues and/or families had serious doubts about their mental capacities. Contrary to conventional wisdom among legal scholars and historians, a thorough survey of Supreme Court historiography reveals that mental decrepitude has been an even more frequent problem on the twentieth-century Court than it was during the nineteenth. The historical evidence convincingly demonstrates that mental decrepitude among aging justices is a persistently recurring problem that merits serious attention.

Until recently no scholarly work has even attempted to examine this consistently overlooked but nonetheless highly instructive aspect of Supreme Court history. David N. Atkinson's Leaving the Bench: Supreme Court Justices at the End is an initially promising but insufficiently thorough evaluation of the relevant biographical evidence. In the end, Atkinson's book simply restates the prevailing conventional wisdom by voicing the overly sanguine conclusion that no formal remedies need to be considered.

$\dagger$ Presidential Distinguished Professor, Emory University School of Law. Research Associate Andrew Larrick and Emory's wonderful Assistant Law Librarian for Interlibrary Loan, Will Haines, each provided exceptionally valuable assistance for this essay. I am also deeply indebted to Dennis J. Hutchinson for multiple kindnesses and extensive advice.

1 David N. Atkinson, Leaving the Bench: Supreme Court Justices at the End (Kansas 1999). Readers thoroughly familiar with the existing literature will quickly realize that three and onehalf of Atkinson's five historically substantive chapters in Leaving the Bench have been published previously and appear here in minimally revised form. See David N. Atkinson, Bowing to the Inevitable: Supreme Court Deaths and Resignations, 1789-1864, 1982 Ariz St L J 615 (which reappears as Chapter Two of Leaving the Bench, 11-45); David N. Atkinson, The Problems of Disabled Justices: Supreme Court Deaths and Resignations: 1865-1900, 38 Drake L Rev 903 (1988-1989) (which reappears as Chapter Three of Leaving the Bench,46-73); and David N. Atkinson, Retirement and Death on the United States Supreme Court: From Van Devanter to Douglas, 45 UMKC L Rev 1 (1976) (which reappears as Chapter Five and the first half of Chapter Six in Leaving the Bench, 104-49). 
Atkinson's failure to note how on three different occasions over the past sixty-five years members of Congress have surmounted conventional wisdom and confronted the danger of mental decrepitude is especially disconcerting. Just like the entire, quite extensive previous historiography, Leaving the Bench completely overlooks a 1937 proposal for a constitutional amendment mandating compulsory retirement of all justices at age seventy-five, which briefly contended for a major role as a possible substitute during the huge public controversy over President Roosevelt's "Court packing" plan. Similarly, Leaving the Bench also inexplicably fails to recount or even mention the equally illuminating but also little-remembered story of how the elite leaders of the American bar subsequently mounted a major push between 1946 and 1955 for the adoption of just such a constitutional amendment to mandate judicial retirement at age seventy-five. Twenty years after that effort fell short, another significant but in the end also unsuccessful legislative attempt to remedy judicial decrepitude was initiated during the late 1970s. All three of these reform efforts underscore how judicial decrepitude has been a recurring issue throughout recent Supreme Court history, and the first two occasions reveal how a realistic constitutional remedy might very well win enactment.

In the spring of 1937, a constitutional amendment mandating retirement at age seventy-five would have been approved by the Congress with virtual acclamation had only President Franklin D. Roosevelt not been so pigheaded as to utterly reject any such substitute for his own badly designed and abysmally presented plan. Seventeen years later, on May 11, 1954, the United States Senate adopted a resolution embracing just such a constitutional alteration. Had it not been for the historical happenstance of the Supreme Court handing down its landmark decision in Brown $v$ Board of Education ${ }^{2}$ only six days later, thus initiating a new era of congressional hostility toward the Court, the amendment's proponents might very well have succeeded in winning enactment of a measure that would have largely remedied the oft-recurring problem of mental decrepitude on the United States Supreme Court.

The abandonment of their effort, however, was not followed by the disappearance or even a diminution of instances of the problem. On the contrary, the post-1954 Supreme Court has featured at least a half-dozen instances in which serious questions were or should have been asked about whether judicial votes were being cast by a less than fully competent justice. The cases of Charles E. Whittaker, Hugo L. Black, William O. Douglas, Thurgood Marshall, and perhaps those of Sherman Minton and Lewis F. Powell, Jr., all indicate how the well

2347 US 483 (1954). 
documented dangers that motivated the leaders of the American bar to push for constitutional reform in the early 1950 s have not been alleviated in the slightest in the years since. Indeed, when Senator Sam Nunn of Georgia mounted his unsuccessful 1970s effort to enact a statutory procedure that would provide for the removal of any justice who became mentally disabled, Nunn realized full well that the problem of mental incapacity has troubled the modern Supreme Court even more than it characterized the nineteenth-century Court. Whenever a justice no longer possesses mental acuity and intellectual energy sufficient to understand, remember, and analyze the cases and arguments that come before the Court, both the immediate parties and American democracy suffer tangible harm.

More than seventy years ago, former Justice and future Chief Justice Charles Evans Hughes emphasized publicly that "[i]t is extraordinary how reluctant aged judges are to retire and to give up their accustomed work.", Over the ensuing years little has changed. The United States Supreme Court since 1990 has featured four justices who continued serving after reaching the age of eighty: William J. Brennan, Jr., Thurgood Marshall, Harry A. Blackmun, and John Paul Stevens. Chief Justice Hughes was an early proponent of mandatory judicial retirement at age seventy-five, and he pointedly warned that "the importance in the Supreme Court of avoiding the risk of having judges who are unable properly to do their work and yet insist on remaining on the bench, is too great to permit chances to be taken." But no constitutional reform has occurred, and thus it remains undeniably true, as Chief Judge Richard A. Posner observed in 1995, that " $[t]$ he judiciary is the nation's premier geriatric occupation." A careful review of both Supreme Court Justices' aggregate biographies, and the little-remembered efforts to enact a corrective amendment, shows that the Court's history offers some powerfully important present-day lessons and reveals how both scholarly knowledge and conventional wisdom are woefully incomplete. Today the conclusion unfortunately re-

3 Charles Evans Hughes, The Supreme Court of the United States: Its Foundation, Methods and Achievements: An Interpretation 75 (Columbia 1928). See also Robert W. Calvert, Mandatory Retirement of Judges, 54 Judicature 424, 427 (1971) (former Chief Justice of the Supreme Court of Texas observing that "old judges rarely retire; they just lean more and more on their law clerks" and advocating mandatory retirement at age seventy); Trafelet $v$ Thompson, 594 F2d 623, 628 (7th $\mathrm{Cir} 1979$ ) (declaring that "[u]sually the reluctance of judges to ask a colleague to step down is exceeded only by his reluctance to do so"); Mordechai Rosenfeld, Rock of Ages, NY L J 2 (Dec 17, 1990) (stating that "[l]ike rocks, the life span of judges is infinite, but only by the judges' own steely reckoning" and advocating mandatory judicial retirement at age seventy).

4 Hughes, The Supreme Court at 76-77 (cited in note 3).

5 Richard A. Posner, Aging and Old Age 180 (Chicago 1995). 
mains, just as Charles Evans Hughes said in 1928, that "[t]he exigency to be thought of is not illness but decrepitude."

\section{THE PRE-CIVIL WAR SUPREME COURT}

Questions of mental incompetency have confronted the United States Supreme Court as far back as its very first decade of existence. In 1795, following the resignation of Chief Justice John Jay, President George Washington nominated John Rutledge of South Carolina as Jay's successor. Rutledge had served as one of the Court's initial associate justices in 1789-91 before resigning to become Chief Justice of the South Carolina Supreme Court, but news of the nomination generated a firestorm of controversy in the summer of 1795 both because of Rutledge's vituperatively outspoken opposition to a newly negotiated treaty between the United States and France and because of widespread questions about Rutledge's mental stability.

Leaving the Bench offers a two-page summary of the Rutledge controversy, but Atkinson's account fails to note or make any use of the one new scholarly study of Rutledge that has been published in the last half-century, James Haw's thoroughly impressive John and Edward Rutledge of South Carolina. ${ }^{8}$ Professor Haw reports that Rutledge's wife Elizabeth passed away in June 1792, and that even though a review of South Carolina Supreme Court decisions from 1792 to 1795 indicates that Rutledge's "recorded judicial opinions show no sign of mental incapacity or eccentricity," other contemporary sources demonstrate that by the time President Washington named Rutledge Chief Justice by means of a recess appointment on July 1,1795 , Rutledge was a "depressed" and "emotionally troubled man." ${ }^{\text {"10 }}$ Haw's understanding is significantly informed by a letter that United States Senator Ralph Izard wrote to a fellow South Carolinian about Rutledge some months later, in November 1795, describing how

6 Hughes, The Supreme Court at 77 (cited in note 3).

See Atkinson, Leaving the Bench at 13-15 (cited in note 1).

8 See James Haw, John and Edward Rutledge of South Carolina (Georgia 1997). See also John S. Goff, Old Age and the Supreme Court, 4 Am J Legal Hist 95, 95 (1960) (calling Rutledge "[t] he most famous case of mental derangement on the Supreme Court"), an article that Leaving the Bench also fails to cite.

9 Haw, John and Edward Rutledge at 227 (cited in note 8).

10 Id at 246, 247. See also id at 257 ("a depression so deep as to produce fits of erratic and even deranged conduct"). For the documents concerning Rutledge's appointment, see Maeva Marcus and James R. Perry, eds, 1 The Documentary History of the Supreme Court of the United States, 1789-1800 94-98 (Columbia 1985). The endnotes in Leaving the Bench concerning the 1789-1800 period include no citations to the marvelously rich Documentary History volumes. See Atkinson, Leaving the Bench at 202-04 (cited in note 1). 
"[a]fter the death of his Wife, his mind was frequently so much deranged, as to be in a great measure deprived of his senses."

But perhaps most important of all was a series of political events that followed fast on the heels of Rutledge's selection. The controversial details of the treaty with France that former Chief Justice Jay had negotiated reached Charleston on July 12, and four days later Rutledge-who on account of eighteenth-century postal service apparently did not yet know that Washington had named him Chief Justice-delivered a widely publicized speech lambasting the proposed treaty in extremely harsh terms. ${ }^{2}$ Later in the month, after news of Rutledge's selection had spread, Haw reports that one leading Charlestonian warned a relative about what he called Rutledge's " $m a d$ frollicks and inconsistent conduct' and 'wild and unproductive' speculations." "13

When Rutledge journeyed to Philadelphia in August of 1795 to sit as Chief Justice of the United States, "he showed no sign of ill temper or of the erratic conduct with which he was charged," Haw reports. ${ }^{14}$ But that demonstration appears to have done Rutledge little if any good, for as Haw notes, "the rising opposition to Rutledge's confirmation stemmed both from politically motivated anger at his vehement Jay Treaty speech and from reports that he was mentally and morally unfit to serve." Haw explains that "[t]he charge of derangement was just part of a broader assault on Rutledge's 'conduct and character.' There was talk of drunkenness, erratic behavior, and refusal to pay debts."

11 See Haw, John and Edward Rutledge at 229 (cited in note 8); Marcus and Perry, eds, 1 Documentary History at 807 (cited in note 10) (letter from Ralph Izard to Jacob Read, Nov 17, 1795).

12 Haw, John and Edward Rutledge at 247-49, 339-40 (cited in note 8); Marcus and Perry, eds, 1 Documentary History at 17,765-70 (cited in note 10). Senator Izard, in his November 1795 letter remarking upon Rutledge having been "deranged" and "deprived of his senses," added that "I am persuaded he was in that situation when the Treaty was under consideration." Marcus and Perry, eds, 1 Documentary History at 807-08.

13 Haw, John and Edward Rutledge at 232 (cited in note 8) (quoting letter from William Read to Jacob Read, July 27, 1795).

14 Id at 252. See also Marcus and Perry, eds, 1 Documentary History at 808 (cited in note 10) (quoting Senator Izard in his November 17,1795 letter to Jacob Read describing Rutledge as "totally altered" since his July speech). For the official records of the Court's August 1795 Term, see Marcus and Perry, eds, 1 Documentary History at 97, 244-55, 396-406, 499-501 (cited in note 10). See also Charles Warren, 1 The Supreme Court in United States History 133-34 (Little, Brown 1923).

15 Haw, John and Edward Rutledge at 250 (cited in note 8). See also Charles Page Smith, James Wilson: Founding Father: 1742-1798 373 (North Carolina 1956); Warren, 1 The Supreme Court in United States History at 129-33 (cited in note 14). Marcus and Perry, eds, 1 Documentary History at 770-817 (cited in note 10), reprints a rich and extensive selection of 1795 commentaries.

16 Haw, John and Edward Rutledge at 253 (cited in note 8). See also Marcus and Perry, eds, 1 Documentary History at 776 (cited in note 10) (quoting Secretary of State Edmund Randolph 
plained the Jay Treaty speech, and the speech in turn proved his derangement."

On December 15, 1795, the United States Senate rejected Rutledge's nomination by a vote of fourteen to ten. ${ }^{18}$ Professor Haw concludes that the nomination "was defeated primarily for political reasons," but even in the weeks immediately preceding the Senate's vote, Chief Justice Rutledge's mental health appears to have taken a very decided turn for the worse. In November, while riding circuit in North Carolina, Rutledge became seriously ill, and his illness exacerbated his depression to such an extent that on his way home to Charleston Rutledge apparently tried "to drown himself at Camden" but without success. ${ }^{20}$ Haw reports that his family tried to guard against another attempt, but early in the morning a day or two after Christmas, Rutledge again attempted to commit suicide, this time by walking or jumping into Charleston's Ashley River. Onlookers saved him, and within a day or two's time Rutledge wrote what Haw terms a "very lucid" letter to President Washington resigning as Chief Justice of the United States."

John Rutledge's mental problems were no doubt quite serious, but no evidence or allegations ever suggested that his mental incapacity affected his obviously very brief official service on the Supreme Court. ${ }^{22}$ That was not the case, however, with Rutledge's colleague William Cushing, who was named as one of the Court's original associate justices in 1789 and remained on the bench until his death in 1810 . Following Rutledge's resignation, Cushing was nominated and immediately confirmed as Chief Justice in January 1796 before refusing the promotion in early February on the grounds of ill health. ${ }^{23}$ One month

to President George Washington, Aug 5,1795, concerning “reports of [Rutledge's] attachment to his bottle").

17 Haw, John and Edward Rutledge at 256 (cited in note 8).

18 See Marcus and Perry, eds, 1 Documentary History at 98-99, 812-15 (cited in note 10).

19 Haw, John and Edward Rutledge at 256 (cited in note 8). See also Warren, 1 The Supreme Court in United States History at 137-39 (cited in note 14) (articulating a similar conclusion).

20 Haw, John and Edward Rutledge at 257 (cited in note 8); Marcus and Perry, eds, 1 Documentary History at 810 (cited in note 10). See also Maeva Marcus, ed, 3 The Documentary History of the Supreme Court of the United States, 1789-1800 83 (Columbia 1990) (documenting Rutledge's illness in Camden).

21 Haw, John and Edward Rutledge at 258 (cited in note 8). See also Marcus, ed, 3 Documentary History at 257-58 (cited in note 20); Marcus and Perry, eds, 1 Documentary History at $817,820-21,822,824,826,831$ (cited in note 10). For the letter itself, see Marcus and Perry, eds, 1 Documentary History at 100.

22 See Marcus, ed, 3 Documentary History at 71, 72 (cited in note 20) (documenting Rutledge's very limited fall 1795 activity on circuit).

23 See Marcus and Perry, eds, 1 Documentary History at 26, 101-04, 834-36 (cited in note 10); Julius Goebel, Jr., 1 History of the Supreme Court of the United States: Antecedents and Beginnings to 1801749 (Macmillan 1971); John D. Cushing, A Revolutionary Conservative: The Pub- 
later United States Senator William Plumer wrote to a New Hampshire friend about the sixty-three-year-old Cushing, saying that "time, the enemy of man, has much impaired his mental faculties."24 Cushing remained on the Court for over fourteen years after Senator Plumer's pronouncement that he was mentally impaired, and John D. Cushing's extensive dissertation reports that Cushing's "final years on the bench were difficult ones .... With his mental facilities waning to the point of deranging his mind, but dependent upon his salary for an income, he remained in service through the intercession of friends who prevailed upon him to continue." ${ }^{25}$ No further or more descriptive contemporary details concerning Cushing's mental incapacity appear to have survived, and as Scott Gerber correctly notes, ${ }^{26}$ most twentieth-century historiographical characterizations of Cushing rely solely on a posthumous description of him as "incompetent" that Justice William Johnson, who served with Cushing from 1804 onward, voiced in an 1822 letter to former President Thomas Jefferson. ${ }^{2}$

What impact Cushing's mental decrepitude may have had upon the Court's consideration or decision of cases remains unaddressed and apparently unanswerable. Following his death in 1810, two full decades passed before another case of clear mental incompetence confronted the Supreme Court. Henry Baldwin of Pennsylvania was named to the Court by President Andrew Jackson in early $1830,{ }^{28}$ but within less than eighteen months the fifty-year-old Baldwin became so

lic Life of William Cushing, 1732-1810 327 (unpublished Ph.D. dissertation, Clark University 1959); Warren, 1 The Supreme Court in United States History at 139-40 (cited in note 14); Henry Flanders, 2 The Lives and Times of the Chief Justices of the Supreme Court of the United States 46, 48 (Cockcroft 1875).

24 Marcus and Perry, eds, 1 Documentary History at 838 (cited in note 10) (quoting William Plumer to Jeremiah Smith, Feb 19, 1796). See also Herbert A. Johnson, The Chief Justiceship of John Marshall, 1801-1835 100 (South Carolina 1997); George Lee Haskins and Herbert A. Johnson, 2 History of the Supreme Court of the United States: Foundations of Power: John Marshall, 1801-1815 87 (Macmillan 1981); Smith, James Wilson at 376 (cited in note 15); Warren, 1 The Supreme Court in United States History at 139 (cited in note 14).

Atkinson's Leaving the Bench offers only a less than one-page treatment of Cushing, see Atkinson, Leaving the Bench at 22-23 (cited in note 1), and makes no use of either the one modern biography of Cushing, see Cushing, $A$ Revolutionary Conservative (cited in note 23), or of a comprehensive and insightful 1998 essay on Cushing, see Scott Douglas Gerber, Deconstructing William Cushing, in Scott Douglas Gerber, ed, Seriatim: The Supreme Court before John Marshall 97 (NYU 1998).

25. Cushing, A Revolutionary Conservative at 329-30 (cited in note 23). See also Warren, 1 The Supreme Court in United States History at 400 (cited in note 14) (noting Cushing's senility in the last "few years" of his service).

26 See Gerber, Deconstructing William Cushing at 99-100 (cited in note 24).

27 See Donald G. Morgan, Justice William Johnson: The First Dissenter: The Career and Constitutional Philosophy of a Jeffersonian Judge 182 (South Carolina 1954); Haskins and Johnson, 2 History of the Supreme Court at 382 (cited in note 24) (quoting the Johnson letter).

28. See Charles Warren, 2 The Supreme Court in United States History 171-73 (Little, Brown 1923). 
displeased that he talked openly of resigning. ${ }^{29}$ Baldwin stayed on, however, and in December of 1832 reports from Philadelphia recounted how "the Honorable Judge Baldwin was seized today with a fit of derangement." Less than two weeks later Daniel Webster alerted a friend to "the breaking out of Judge Baldwin's insanity,", and another correspondent observed more pithily that "Judge Baldwin is out of his wits." ${ }^{32}$ Baldwin was hospitalized for what was called "incurable lunacy" and missed the entire 1833 term of Court." Baldwin's colleague Joseph Story informed Circuit Judge Joseph Hopkinson in May 1833 that "I am sure he cannot be sane. And, indeed, the only charitable view, which I can take of any of his conduct, is, that he is partially deranged at all times." ${ }^{34}$

But Justice Baldwin nonetheless returned to active service on the Supreme Court, and remained a voting member of the Court for eleven more years until his death in April 1844 at age sixty-four. Legal historian G. Edward White has concluded that "[i]t is hard to say how much of Baldwin's incoherence as a jurist resulted from his mental problems," ${ }^{35}$ but no truly comprehensive study of Baldwin's signed opinions, or of his voting record on argued cases, ever appears to have been carried out. As Atkinson's one page treatment of Baldwin appropriately highlights, ${ }^{36}$ in 1838 the Supreme Court's Reporter of Decisions, Richard Peters, Jr., told Judge Hopkinson that most courtroom observers of Baldwin agreed that "his mind is out of order. I have

29 See id at 257-58. See also Jean Edward Smith, John Marshall: Definer of a Nation 510 (Holt 1996) (asserting that even in 1831, "Baldwin was in the early stages of a mental breakdown").

30 G. Edward White, 3-4 History of the Supreme Court of the United States: The Marshall Court and Cultural Change, 1815-1835 299 (Macmillan 1988) (quoting Henry Etting to Levi Woodbury, Dec 22, 1832). See also Carl B. Swisher, 5 History of the Supreme Court of the United States: The Taney Period, 1836-64 51 (Macmillan 1974) (noting reports of Baldwin's insanity).

31 Smith, John Marshall: Definer of a Nation at 674 n 146 (cited in note 29); White, 3-4 History of the Supreme Court at 299 (cited in note 30) (both quoting Daniel Webster to Warren Dutton, Jan 4,1833).

32 White, 3-4 History of the Supreme Court at 299 (cited in note 30) (quoting P.C. Brooks to Edward Everett, Jan 3, 1833).

33 See Carl Brent Swisher, Roger B. Taney 211-12 (Macmillan 1935). See also Smith, John Marshall: Definer of a Nation at 510 (cited in note 29).

34 Burton Alva Konkle, Joseph Hopkinson: 1770-1842: Jurist: Scholar: Inspirer of the Arts 286 (Pennsylvania 1931) (quoting Joseph Story to Joseph Hopkinson, May 9, 1833). See also Smith, John Marshall: Definer of a Nation at $674 \mathrm{n} 146$ (cited in note 29); White, 3-4 History of the Supreme Court at 298 (cited in note 30); Gerald T. Dunne, Justice Joseph Story and the Rise of the Supreme Court 376 (Simon \& Schuster 1970).

35 White, 3-4 History of the Supreme Court at 301 (cited in note 30). See also R. Kent Newmyer, The Supreme Court Under Marshall and Taney 93 (Crowell 1968) (referring to "Baldwin's sporadic madness and consistent paranoia"); R. Kent Newmyer, Supreme Court Justice Joseph Story: Statesman of the Old Republic 311 (North Carolina 1985) (concluding that "Baldwin's mental condition continued to deteriorate after his breakdown in 1833").

36 See Atkinson, Leaving the Bench at 32-33 (cited in note 1). 
heard in one day not less than five persons . . . say 'he is crazy.","37 Nonetheless, records from the 1830 s and 1840 s fail to indicate that any effort was ever made to remove Baldwin from his post as an Associate Justice.

\section{THE SUPREME COURT FROM THE CIVIL WAR TO WORLD WAR I}

After Baldwin's death in 1844, a full quarter century passed before the Court was again confronted with another case of a mentally disabled justice who nonetheless continued to participate actively in the Court's work. Justice Robert C. Grier was named to the Court in 1846 by President James K. Polk at the age of fifty-two, and for at least fifteen years Grier carried out his judicial duties in a distinctly aboveaverage fashion. ${ }^{3}$ After being stricken with paralysis in the summer of 1867, however, Grier's mental competency began to deteriorate significantly, and by the fall of 1869 Grier's mental incapacity was beyond any doubt.

On November 27, 1869, the Court met in conference to discuss both the celebrated case of Hepburn $v$ Griswold ${ }^{40}$ and a less noted case posing some similar issues, Broderick's Executor v Magraw." The Court that day was composed of just eight justices, for statutory reauthorization of a ninth seat was scheduled to take effect only on December 1 , the same day on which a wholly new statutory provision allowing justices with at least ten years of service to retire with full pay

37 White, 3-4 History of the Supreme Court at 302 (cited in note 30) (quoting Richard Peters, Jr., to Joseph Hopkinson, Mar 18,1838). See also David J. Danelski, A Supreme Court Justice Steps Down, 54 Yale Rev 411 (1965) (quoting Richard Peters, Jr., as writing to Joseph Story in 1838 that Justice Baldwin "was entirely deranged!!"); Swisher, 5 History of the Supreme Court at 52 n 53 (cited in note 30) (quoting Chief Justice Roger B. Taney as remarking upon Justice Baldwin's "unhappy state of mind" in a June 3, 1840 letter to Richard Peters, Jr.).

38 See Van Vechten Veeder, $A$ Century of Federal Judicature. IV., 15 Green Bag 181, 181, 182 (1903) (observing that Grier "does not seem to be as widely known as the merit of his work warrants" and commenting that "no other justice of the court has surpassed the ease, accuracy and finish of his written style"); Willard L. King, Lincoln's Manager: David Davis 202 (Harvard 1960) (calling Grier "[t]he most brilliant" of the five Democratic Associate Justices sitting on the Court in 1862); Swisher, 5 History of the Supreme Court at 232-33 (cited in note 30) (noting that Grier served with "industry and vigor" and "as a judge, his friends had appraised him well"). See also Charles Warren, 3 The Supreme Court in United States History 204-06 (Little, Brown 1924) (discussing contemporaneous accounts praising Grier).

39 See Resignation of Mr. Justice Grier, 75 US ( 8 Wall) vii, vii (1870) (dating and describing Grier's physical incapacitation); Charles Fairman, Mr. Justice Miller and the Supreme Court, 1862-1890 164 (Harvard 1939) (stating that Justice Grier's private letters indicate that he was "failing" even well before the 1867 paralysis and quoting Justice Samuel F. Miller as saying that Grier "is getting a little muddy" in a Jan 19, 1868 letter); Peter G. Fish, Secrecy and the Supreme Court: Judicial Indiscretion and Reconstruction Politics, 8 Wm \& Mary L Rev 225, 236, 241 (1967) (citing contemporaneous documents indicating that Justice Grier was erratically indecisive even in 1866).

4075 US (8 Wall) 603 (1870).

4175 US (8 Wall) 639 (1870). 
upon reaching age seventy also would become effective. ${ }^{42}$ During the conference discussion of Hepburn, in which the Court of Appeals of Kentucky had held the Legal Tender Act of 1862 invalid, Justice Grier voted to reverse that holding. Coupled with the similar votes of Justices Miller, Davis, and Swayne, the result was a four to four tie, thus affirming the decision below but not resulting in any determinative ruling on the status of the Legal Tender Act. During the ensuing discussion of Broderick's Executor, however, as Justice Miller subsequently recounted, Grier "made some remarks. He was told that they were inconsistent with his vote in the former case." Grier thus changed his vote in Hepburn, providing Chief Justice Salmon P. Chase with a five-member majority.

Even though Chief Justice Chase was intensely committed to using Grier's vote to support a majority decision invalidating the Legal Tender Act, Grier's demonstration of mental incapacity during the conference discussion was such that every one of his colleagues acknowledged that action had to be taken. As Justice Miller later recalled, within "a week from that day every Judge on the bench authorized a committee of their number to say to the Judge who had reconsidered his vote, that it was their unanimous opinion that he ought to resign" and make use of the new retirement statute which had taken effect on December 1 . $^{44}$ Chief Justice Chase and Justice Nelson called on Grier in the presence of Grier's daughter, and on December 15 Justice Grier sent a letter to President Grant retiring from the Court effective January 31,1870 . $^{45}$

42 See Act of April 10, 1869, 16 Stat 44. See also Alpheus Thomas Mason, Politics and the Supreme Court: President Roosevelt's Proposal, 85 U Pa L Rev 659, 668-71 (1937) (discussing the bill's legislative history); Charles Fairman, The Retirement of Federal Judges, 51 Harv L Rev 397, 416 (1938); Charles Fairman, Mr. Justice Bradley's Appointment to the Supreme Court and the Legal Tender Cases, 54 Harv L Rev 1128, 1145 (1941) (noting that the Court had only eight members when it took up the Hepburn case); Harold H. Burton, The Legal Tender Cases: A Celebrated Supreme Court Reversal, 42 ABA J 231, 232 (1956) (same).

43 Charles Bradley, The Legal Tender Cases in 1870, in Charles Bradley, ed, Miscellaneous Writings of the Late Hon. Joseph P. Bradley 73-74 (Hardham 1901) (reprinting an account of the November 27 conference prepared by Justice Miller in April 1870). See also Charles Fairman, 6 History of the Supreme Court of the United States: Reconstruction and Reunion, 1864-1888 716 (Macmillan 1971).

44 Bradley, The Legal Tender Cases in 1870 at 73-74 (cited in note 43) (reprinting Justice Miller's April 1870 account of what transpired). See also Fairman, 6 History of the Supreme Court at 716-17 (cited in note 43); King, Lincoln's Manager at 273 (cited in note 38). See also Fairman, 54 Harv L Rev at 1145 (cited in note 42).

45 See Resignation of Mr. Justice Grier, 75 US (8 Wall) at vii (cited in note 39); Fairman, 51 Harv L Rev at 418-19 (cited in note 42). A small controversy exists concerning precisely which of Justice Grier's colleagues spoke to him to request his retirement. By far the most persuasive analysis is that offered by Charles Alan Wright. See Charles Alan Wright, Authenticity of " $A$ Dirtier Day's Work" Quote In Question, 11 S Ct Hist Soc Q 6 (1990). See also Atkinson, Leaving the Bench at 50 (cited in note 1); David N. Atkinson, Who Asked Justice Grier to Resign?, $16 \mathrm{~S} \mathrm{Ct}$ Hist Soc Q 5 (1995) (reprinted as Appendix A in Leaving the Bench); Hughes, The Supreme 
Grier's retirement, however, failed to save the Court from an ignominious and embarrassing official episode. At conference on January 29,1870, with Grier still present, Chase obtained official approval of his Hepburn majority opinion, which he aimed to hand down on January 31, Grier's final day on the bench. Justice Miller's preparation of a dissent, however, understandably delayed official announcement of the decision until February 7, at which time Chase proclaimed that the vote of Justice Grier, even though Grier was no longer on that day a serving member of the Court, nonetheless stood behind the Hepburn majority holding.

History has not been kind to Chief Justice Chase's insistence "on deciding a constitutional issue when one justice did not really know what he was about" and thus "declaring an Act of Congress invalid by the vote of a confused mind." propriate in light of the fact that President Grant's two new appointees, William Strong and Joseph P. Bradley, both of whom were named to the Court on that very same day of February 7 (one replacing Grier and the other assuming the new ninth seat), were predictable supporters of the Legal Tender Act. ${ }^{48}$ In addition, as one careful student of the cases has emphasized, "Measured by the intensity of the public debate at the time," the legal tender battle represented "one of the leading constitutional controversies in American history" and Hepburn itself was "one of the first cases to hold substantive Congressional legislation unconstitutional." ${ }^{49}$ Quite unsurprisingly, the constitutional question of the Legal Tender Act's validity reappeared on the Court's docket within just one year's time, and in May of 1871 a new fiveJustice majority composed of Miller, Davis, Swayne, Strong, and Bradley explicitly overruled Hepburn $v$ Griswold. ${ }^{\text {so }}$ As Charles Fairman, the

Court at 76 (cited in note 3). See also note 69.

46 See Hepburn, 75 US ( 8 Wall) at 626.

It is proper to say that Mr. Justice Grier, who was a member of the court when this case was decided in conference [November 27, 1869], and when this opinion was directed to be read [January 29, 1870], stated his judgment to be that the legal tender clause, properly construed, has no application to debts contracted prior to its enactment; but that upon the construction given to the act by the other judges he concurred in the opinion that the clause, so far as it makes United States notes a legal tender for such debts, is not warranted by the Constitution.

Id (footnoted text in brackets). See also Fairman, Mr. Justice Miller and the Supreme Court at 160-62 (cited in note 39) (describing in some detail Justice Grier's stance concerning the Legal Tender Act and concluding that "[i]t is impossible to support his position"); Fairman, 6 History of the Supreme Court at 717 (cited in note 43); Burton, 42 ABA J at 233 (cited in note 42).

47 Fairman, Mr. Justice Miller and the Supreme Court at 166 (cited in note 39); Fairman, 6 History of the Supreme Court at 719 (cited in note 43).

48 See Fairman, 54 Harv L Rev at 1145-46 (cited in note 42); Hughes, The Supreme Court at $52-53$ (cited in note 3 ).

49 Kenneth W. Dam, The Legal Tender Cases, 1981 S Ct Rev 367,367-68.

50 See Knox v Lee and Parkerv Davis ("Legal Tender Cases"), 79 US (12 Wall) 457, 553-54 
leading scholar of the late-nineteenth-century Court, later observed, "[h]istory has surely vindicated the result which the new majority imposed.",si

Chief Justice Chase's egregiously bad behavior merits most of the condemnation for the institutional dishonor that the Supreme Court inflicted upon itself in the legal tender controversy, ${ }^{52}$ but there is no gainsaying the fact that it was only the presence of a mentally incompetent justice that allowed Chase to manipulate the Court's consideration of Hepburn in the way that he did.

Following the legal tender debacle, however, less than a decade passed before the Court was confronted with yet another case of manifest mental incompetence on the high bench. Justice Nathan Clifford had joined the Court in 1858 at age fifty-four as a nominee of President James Buchanan, and for approximately fifteen years Clifford provided the Court with more than acceptable judicial service. By at least 1877, however, Clifford's mental capacity was declining, and Justice Miller informed one correspondent in March of that year that Clifford's "mental failure is obvious to all the Court." In early 1878 , Chief Justice Waite assigned Clifford the opinion in a case in which Clifford at conference had voted with the Court's majority, but Clifford rejected the assignment, telling Waite that "I think I did not vote for the judgement." Waite's biographer later concluded that this was "a clear instance of [Clifford's] mental failure."

Clifford nonetheless continued to participate actively in the work of the Court, and his deterioration led Justice Miller to observe that "in the work we have to do no man ought to be there after he is seventy." Clifford's continuing presence on the Court also appears to have informed an 1878 speech that Justice Miller delivered to the New York State Bar Association, in which he forthrightly asserted that

(1871) (explaining that Hepburn "was decided by a divided court, and by a court having a less number of judges than the law then in existence provided this court shall have. These cases have been heard before a full court.").

51 Fairman, 54 Harv L Rev at 1143 (cited in note 42).

52 See Hughes, The Supreme Court at 51, 52 (cited in note 3) (saying that the legal tender controversy "brought the Court into disesteem" and "shook popular respect for the Court").

53 See Warren, 3 The Supreme Court at 44-46, 274, 345 (cited in note 38). See also Philip Greely Clifford, Nathan Clifford: Democrat 270-94 (G.P. Putnam's Sons 1922).

54 Fairman, 51 Harv L Rev at 421 (cited in note 42) (quoting a Mar 18, 1877 letter written by Justice Miller to William Pitt Ballinger); Fairman, Mr. Justice Miller and the Supreme Court at 351 (cited in note 39) (same).

55 C. Peter Magrath, Morrison R. Waite: The Triumph of Character 261 (Macmillan 1963) (quoting Nathan Clifford to Morrison R. Waite, Jan 27, 1878). The case at issue was United States $v$ Morrison, 96 US 232 (1878).

56 Magrath, Morrison R. Waite at 261 (cited in note 55).

57 Fairman, 51 Harv L Rev at 421 (cited in note 42); Fairman, Mr. Justice Miller and the Supreme Court at 351 (cited in note 39) (both quoting Samuel F. Miller to William Pitt Ballinger, Mar 18, 1877). 
some new method above and beyond the "utterly inadequate" congressional power of impeachment needed to be available for displacing disabled justices. "There are many matters which ought to be causes of removal that are neither treason, bribery, nor high crimes or misdemeanors." Miller included some purely "[p]hysical infirmities" on his list, but he specifically identified "the decay of the faculties by reason of age, insanity, [and] prostration by disease from which there is no hope of recovery - these should all be reasons for removal, rather than that the administration of justice should be obstructed or indefinitely postponed.".88

Within months, however, the Court's situation took a decided turn for the worse when Justice Ward Hunt, already a physically weak presence on the bench, was struck speechless with paralysis in early January of 1879. Appointed to the Court only in 1873, Hunt lacked the ten years of service necessary for paid retirement pursuant to the 1869 statute. Thus Hunt remained in office, although rarely if ever participating in the work of the Court, until a special pension bill for him was approved by the Congress in January $1882^{5 \circ}$

More than eighteen months before Hunt's tardy departure, however, Justice Clifford's mental incapacity reached truly crisis proportions when he suffered some form of a stroke just prior to the beginning of October Term 1880. Justice Miller described the situation bluntly: "Judge Clifford reached Washington on the 8th [of] October a babbling idiot. I saw him within three hours after his arrival, and he did not know me or any thing, and though his tongue framed words there was no sense in them." "Fortunately for the Court, Clifford did not actively participate in any of its work during the 1880 term. However, even though Clifford, unlike Hunt, qualified for paid retirement under the 1869 statute, he nonetheless retained his seat until the time of his death on July 25,1881 . By way of an obituary notice, The Nation magazine publicly observed that Clifford's "mental faculties had been

58 Samuel F. Miller, 2 Proceedings of the New York State Bar Association 31, 39-40 (1878). See also Fairman, Mr. Justice Miller and the Supreme Court at 379 (cited in note 39) (quoting much of the relevant portion of Justice Miller's remarks).

59 See Act of January 27, 1882, 22 Stat 2. See also Fairman, Mr. Justice Miller and the Supreme Court at 376-78 (cited in note 39) (describing the deterioration of Hunt's health); Charles Fairman, 7 History of the Supreme Court of the United States: Reconstruction and Reunion, 1864 1888, Part Two 443, 519-20, 523-24 (Macmillan 1987) (noting Hunt's incapacitation); Magrath, Morrison R. Waite at 235, 269 (cited in note 55); Emily Field Van Tassel, Resignations and Removals: A History of Federal Judicial Service-and Disservice-1789-1992, 142 U Pa L Rev 333, 401-02 (1993) (noting the special pension bill passed on Hunt's behalf). Historians of the Waite Court have also concluded that Justice Noah Swayne's "mental powers were failing" by 1879, at which time Swayne was seventy-four years old. See Magrath, Morrison R. Waite at 268.

60 Fairman, 7 History of the Supreme Court at 521 (cited in note 59) (quoting a Samuel F. Miller letter written on Nov 28, 1880). See also Clifford, Nathan Clifford: Democrat at 341 (cited in note 53). 
impaired for some time previous to his death, and his place on the bench has been practically vacant in consequence. He refused to resign, however, in the hope that the election of a Democratic President might render certain the appointment of a Democratic successor." ${ }^{.61} \mathrm{Ir}-$ respective of whatever motives Clifford or his political allies may have had, however, Clifford's ongoing presence as a mentally incapacitated justice inflicted clear public harm upon the Supreme Court to a degree that stopped just short of what had been incurred in the case of Justice Grier.

After Clifford's exit, fifteen years passed before the Court confronted its next mental incapacity crisis. This time it involved Justice Stephen J. Field, who had joined the Court in 1863 at age forty-six and hence had witnessed what happened when first Grier and then Clifford had remained on the bench too long. The primary biographer of Melville Weston Fuller, who succeeded Morrison R. Waite as Chief Justice of the United States in 1888, concluded that even "[i]n the early [eighteen] nineties Justice Field's mind began to fail." "During 1892-93 Field provoked a prolonged controversy within the Court over the wording of the official headnote to the decision in O'Neil $v$ Vermont, ${ }^{63}$ and in early 1895 Justice John Marshall Harlan told his sons that Field had acted "like a mad man" during the Court's consideration of the Income Tax Cases. Field's own principal biographer, Carl Brent Swisher, wrote in 1930:

During the winter of 1896-97 Field's mind became noticeably feeble. His questions in the court room at times indicated that he had no conception of the arguments that were being made before him. It was reported that he voted on cases and then forgot how he had voted .... His colleagues at times found it wise to coach him on cases before them.

61 The Nation 62 (July 28, 1881). See also Fairman, 7 History of the Supreme Court at 522 (cited in note 59) (noting that Clifford did not "drop[ ] out" until the beginning of October Term 1880).

62 Willard L. King, Melville Weston Fuller: Chief Justice of the United States: 1888-1910 222 (Macmillan 1950).

63144 US 323 (1892). See Alan F. Westin, Stephen J. Field and the Headnote to O'Neil v. Vermont: A Snapshot of the Fuller Court at Work, 67 Yale L J 363 (1958) (documenting the battle, initiated by Field, over the United States Reports headnote to O'Neil v Vermont).

64 Owen M. Fiss, 8 History of the Supreme Court of the United States: Troubled Beginnings of the Modern State, 1888-1910 29 (Macmillan 1993) (quoting John Marshall Harlan to James and John Harlan, May 24, 1895).

65 Carl Brent Swisher, Stephen J. Field: Craftsman of the Law 442 (Brookings 1930). See also Paul Kens, Justice Stephen Field: Shaping Liberty from the Gold Rush to the Gilded Age 262 (Kansas 1997) (stating that in the winter of 1896, Field's "mind was becoming noticeably weaker. Colleagues observed that he had difficulty following arguments and that he voted on cases and then forgot how he had voted."); James W. Ely, Jr., The Chief Justiceship of Melville W. Fuller, 1888-1910 47 (South Carolina 1995) (concluding that in the mid-1890s Field "alternated between 
Apparently even at some point in late 1895 or very early 1896 , Chief Justice Fuller attempted to persuade Field to retire but met with no success. As a result, Fuller henceforth assigned no further majority opinions to Field. ${ }^{66}$ During October Term 1895, Field delivered just two minor opinions on behalf of the Court in the last months of $1895^{67}$ and then just a single majority opinion in March of $1896 .{ }^{68}$ That opinion turned out to be the final occasion on which Stephen J. Field spoke for the Supreme Court, even though he remained a voting member of the high bench for another twenty months, finally retiring on December $1,1897 .^{\circ}$

Soon after news of Field's impending departure became public in October $1897,{ }^{70}$ a reporter for the Chicago Times-Herald, Walter Wellman, printed an embarrassingly detailed story describing how two unnamed justices had visited Field one evening the previous spring to "coach" him concerning a draft opinion. Field by that time was eighty years old, and his visitors found him

in an unusually lethargic condition. He sat in a big armchair, his head bowed down upon his breast, his eyes closed. It was with

periods of lucidity and periods of senility").

66 See Ely, The Chief Justiceship of Melville W. Fuller at 48 (cited in note 65) (relying upon a Mar 7,1896 letter from Stephen J. Field to Melville W. Fuller).

67 See Stewart v McHarry, 159 US 643 (1895); Keane v Brygger, 160 US 276 (1895).

68 See Telfener $v$ Russ, 163 US 100 (1896). Justice Field did author seven concurring, dissenting, or concurring and dissenting opinions during the final three months of October Term 1895. See Wong Wing v United States, 163 US 228, 238 (1896) (concurring in part and dissenting in part); Central Pacific Railroad Co v Nevada, 162 US 512, 527 (1896) (dissenting); Woodruff v Mississippi, 162 US 291, 304 (1896) (concurring); Southem Pacific Railroad Co v Califormia, 162 US 167, 168 (1896) (dissenting); Central Pacific Railroad Co v California, 162 US 91, 128 (1896) (dissenting); Brown v Walker, 161 US 591, 628 (1896) (dissenting); Geer v Connecticut, 161 US 519,535 (1896) (dissenting).

69 See King, Melville Weston Fuller at 224-27 (cited in note 62); Swisher, Stephen J. Field at 444-45 (cited in note 65). Future Chief Justice Charles Evans Hughes subsequently related in 1928 how Justice John Marshall Harlan, with whom he served only during October Term 1910, had told him of speaking to Field sometime in the 1890s in an effort to secure Field's retirement. Harlan said he had reminded Field of how Field had once previously described to him how Field had told Justice Grier in 1869 that it was time for Grier to retire. Field supposedly replied, "Yes! And a dirtier day's work I never did in my life." As Professor Wright has suggested, this tale may be more apocryphal than accurate, for "all experience teaches that memories fail over the years and that stories tend to get better as time passes."Wright, $11 \mathrm{~S} \mathrm{Ct}$ Hist Soc Q at 7 (cited in note 45). See also Atkinson, Leaving the Bench at 71, 186 (cited in note 1); Hughes, The Supreme Court at 76 (cited in note 3); and note 45.

70 See Walter Wellman, Justice Field to Rest, Chi Times-Herald 1 (Oct 13, 1897); Field Will Quit Dec. 1, Chi Times-Herald 5 (Oct 15, 1897). The October 13 story noted that Field "has failed rapidly in strength" over the preceding year and that "[h]e is unable to get about without assistance. His mind, however, is said to be as clear as a bell concerning all legal questions, however dull his memory may be as to the ordinary affairs of life." The October 15 story stated that "Although the resignation does not take effect until Dec. 1 it is the understanding that he will not resume his seat on the bench during the interim." See also Supreme Court Opens, Chi TimesHerald 12 (Oct 12, 1897) (describing how Justice Field "leaned heavily upon the arm of Justice Harlan" in order to remain on his feet during an October 11 visit to the White House). 
difficulty that he recognized his callers and exchanged a few words with them. Then his eyes closed again, and the two justices looked at one another as if to inquire what should be done next."

"Finally," Wellman recounted, one of the visitors took out a detailed statement of the case.

He asked permission to read this to Justice Field, and taking silence as consent proceeded to read aloud. For some minutes Justice Field's head lay still upon his breast. His eyes remained closed. No one in the room could be sure that he understood a word that was uttered.

But presently the old justice lifted his head and opened his eyes. It seemed that the legal phrases, the constitutional arguments, the statements of law so familiar through all these years to his mind had at last roused the sleeping brain to activity. In another moment or two Justice Field raised his right hand, warningly.

"Read that again," he commanded.

When the passage had been reread the veteran jurist exclaimed: "That is not right. That is not good law. You err when you say so-andso."

And then Mr. Field, now thoroughly roused, delivered an argument which for depth, clearness and force astonished both his listeners. This done, he relapsed into his former comatose condition. When the two visitors gathered up their papers and left the room Justice Field was still asleep. He did not know when they left. ${ }^{n}$

Wellman all but admitted that this had been recounted to him by one of the two visitors themselves.

When the two justices compared notes on their way downtown together they were both forced to admit that Justice Field was right. He had assaulted their position so successfully that they were forced to abandon it. And in this way, as a matter of fact the aged jurist really overturned a decision of the court, for other justices who agreed with these two were also forced to change their views when the arguments advanced by Mr. Field were reported to them by their colleagues.

71 Walter Wellman, Story of Justice Field, Chi Times-Herald 6 (Oct 16, 1897).

72 Id.

73 Id. See also King, Melville Weston Fuller at 222-23 (cited in note 62), who suggests that the opinion in question likely was one or the other of the Court's (and Field's) two early 1896 rulings in Telfener $v$ Russ, 162 US 170 (1896), on rehearing, 163 US 100 (1896), which was the last case in which Field wrote on behalf of the Court. Wellman's October 1897 account, however, ex- 
Wellman concluded:

To this day it is an open question with the two justices who called on Mr. Field that night whether or not the veteran was fully conscious at the time he delivered his argument. It seemed to them that the legal phrases which his ears heard and carried to his brain simply roused his mind to a sort of automatic activity. Once set going, that mind operated with accuracy and unfailing logic, apparently without effort. At least nothing else, no other sort of mental stimulus, could at that moment have found response in coherency in his mind. He was oblivious to everything save his second nature, which was the law and its interpretation.

Automatic or not, little doubt exists that Justice Field remained on the Court for at least two years beyond when his mental incapacity should have prompted his retirement. One of his colleagues, Justice Henry Billings Brown, who himself quite willingly chose to step down from the bench at age seventy, later wrote that in his experience many justices were still intellectually effective at age seventy, but that those who remained beyond that age were no longer competent by age eighty. "During that decade the work of the Supreme Court tells heavily upon the physique of its members, and sometimes incapacitates them before they are aware of it themselves .... Of the four men of our Court who lost their minds, all of them lost them while they were still upon the Bench."

Following Field's replacement by Justice Joseph McKenna in early 1898, a full decade passed before further difficulties caused by judicial disabilities confronted the Court. By the outset of October Term 1909, Justice William Moody, who had joined the Court less than three years earlier at age fifty-two, had become completely incapacitated as a result of what apparently was one or another form of amyotrophic lateral sclerosis ("ALS")." In late October Justice Rufus W.

plicitly dates the event to "[l]ast spring," or early in 1897, thus vitiating King's interpretation. Wellman, Story of Justice Field, Chi Times-Herald at 6 (cited in note 71).

74 Wellman, Story of Justice Field, Chi Times-Herald at 6 (cited in note 71). As Field's biographer Carl Swisher echoed quite similarly, "it remained an open question with [the two justices] whether Field had been fully conscious when he delivered his argument. It was as if the legal phrases read in his presence had stimulated his mind to a sort of automatic activity." Swisher, Stephen J. Field at 443 (cited in note 65).

75 Charles A. Kent, ed, Memoir of Henry Billings Brown: Late Justice of the Supreme Court of the United States 32, 95 (Duffield 1915). See also Fairman, 51 Harv L Rev at $429 \mathrm{n} 83$ (cited in note 42 ) (suggesting that "[p]robably the four to whom" Brown was referring were Baldwin, Grier, Clifford and Field, with only the last of whom Brown himself had served).

76 See Atkinson, Leaving the Bench at 80 (cited in note 1); Jeffrey O'Connell and Thomas E. O'Connell, Book Review, The Justice from Beacon Hill: The Life and Times of Oliver Wendell Holmes, 37 SLU L J 169, 178 \& n 59 (1992) (discussing possible causes of Moody's illness); Judith R. McDonough, William Henry Moody v, 211 (unpublished Ph.D. dissertation, Auburn University 1983) (stating that Moody suffered from "debilitating rheumatism"). Moody did not resign 
Peckham died at age seventy, and five months later Justice David J. Brewer died suddenly at age seventy-three. New Justice Horace $H$. Lurton took Peckham's seat in December 1909, but the uppermost problem throughout what one careful historian later called "[p]erhaps the worst year in the history of the Court" "was the growing enfeeblement of seventy-seven-year-old Chief Justice Melville Fuller. The Chief Justice's biographer readily acknowledged that Fuller "stayed on the bench slightly longer than he should,", but any danger of Fuller staying on for yet another term ended with Fuller's sudden death in early July of 1910. Justice Oliver Wendell Holmes, who had joined the Court in 1902, poignantly informed a friend that "[t]he Chief died at just the right moment, for during the last term he had begun to show his age in his administrative work, I thought, and I was doubting whether I ought to speak to his family, as they relied on me." ${ }^{\text {,9 }}$

\section{THE SUPREME COURT FROM WORLD WAR I TO 1937}

Following Chief Justice Fuller's death, more than a decade went by before the increasing mental decrepitude of Justice Joseph McKenna, who had succeeded Stephen J. Field in 1898, produced the Court's next internal crisis. Several federal judges who were well acquainted with McKenna's previous work as a circuit judge had strongly and explicitly opposed his Senate confirmation in the belief that McKenna's legal abilities fell well below the minimum standard for the United States Supreme Court, ${ }^{\text {sD }}$ but McKenna's performance during his first twenty years of service on the high bench appears to have been at least minimally adequate. ${ }^{\text {s1 }}$ Charles Evans Hughes, who

his seat until Congress, as in the case of Justice Hunt, passed a special pension bill on June 23, 1910. See An Act to Permit William H. Moody, an Associate Justice of the Supreme Court of the United States, to Retire, 36 Stat 1861 (1910); McDonough, William Henry Moody at 216-17 (noting that a "special bill had to be passed" to allow Moody to retire with benefits); Van Tassel, 142 U Pa L Rev at 402 (cited in note 59). See also Editorial, Judges under Disability, 16 Va L Reg 218, 218-19 (1910) (asserting vis-à-vis Moody that "some method should be devised by which a Judge appointed for life should be retired upon proof of the fact that he was physically or mentally unable to perform his duties"). On Moody's appointment, see the excellent article by Paul T. Heffron, Theodore Roosevelt and the Appointment of Mr. Justice Moody, 18 Vand L Rev 545 (1965).

77 King, Melville Weston Fuller at 309 (cited in note 62).

78 Id. See also John R. Schmidhauser and Larry L. Berg, The Supreme Court and Congress: Conflict and Interaction, 1945-1968 71 (Free Press 1972) (asserting that Chief Justice Fuller "bordered on senility" during October Term 1909); John R. Schmidhauser, When and Why Justices Leave the Supreme Court, in Wilma Donahue and Clark Tibbitts, eds, Politics of Age 117,121 (Michigan 1962).

79 King, Melville Weston Fuller at 310 (cited in note 62) (quoting Oliver Wendell Holmes to Baroness Moncheur, July 10,1910).

80 See id at 228-29. See also Matthew McDevitt, Joseph McKenna: Associate Justice of the United States 103-05 (Catholic 1946); Warren, 3 The Supreme Court at 441-42 (cited in note 38).

81 See Walter F. Pratt, Jr., The Supreme Court under Edward Douglass White, 1910-1921 
served with McKenna from 1910 to 1916, later wrote that even in those years McKenna was an indecisive jurist. "He had little to say in conference [and] was hesitant to express a definite view, often saying that he would prefer not to vote until he could 'see the opinion."'s

In any case, by the summer of 1921, when former President William Howard Taft succeeded the late Edward Douglass White as Chief Justice of the United States, the seventy-eight-year-old McKenna's mental acuity had certainly begun to slip. In April of 1922, after an initial six months of experience with McKenna during October Term 1921, Chief Justice Taft complained to his brother Horace about McKenna's mental incompetence: "In case after case he will write an opinion and bring it into conference, and it will meet objection because he has missed a point in one case, or, as in one instance, he wrote an opinion deciding the case one way when there had been a unanimous vote the other, including his own." already had unsuccessfully broached the subject of retirement with McKenna, for the problem of having a mentally incapacitated Justice on the Court was dire indeed: 'McKenna's vote may change the judgment of the Court on important issues, and it is too bad to have a man like that decide when he is not able to grasp the point, or give a wise and deliberate consideration of it." ${ }^{\text {s4 }}$

Indeed, as David J. Danelski has argued, Justice McKenna may very well have not fully understood what he was doing when he cast his decisive vote with the five-to-four majority in Truax $v$ Corrigan, ${ }^{25}$ a December 1921 decision striking down an Arizona law prohibiting judicial injunctions against labor protests. "Since McKenna was moderately sympathetic to labor, one might have expected him to uphold the statute as Holmes, Brandeis, Clarke and Pitney voted to do in conference. But McKenna cast his crucial vote with the conservatives and

(South Carolina 1999). But see Loren P. Beth, John Marshall Harlan: The Last Whig Justice 164 (Kentucky 1992) (observing that even in the years up through 1911, Justice McKenna's voting on decided cases "seemed almost random, following no consistent pattern").

82 David J. Danelski and Joseph S. Tulchin, eds, The Autobiographical Notes of Charles Evans Hughes 170 (Harvard 1973). See also Alexander M. Bickel and Benno C. Schmidt, Jr., 9 History of the Supreme Court of the United States: The Judiciary and Responsible Government, 1910 192169 (Macmillan 1984).

83 Alpheus Thomas Mason, William Howard Taft: Chief Justice 213 (Simon and Schuster 1965) (quoting William Howard Taft to Horace D. Taft, Apr 17,1922).

84 Id at 214. See also Sheldon M. Novick, Honorable Justice: The Life of Oliver Wendell Holmes 345 (Little, Brown 1989); McDevitt, Joseph McKenna at 228 (cited in note 80).

85257 US 312 (1921). 
held fast." ${ }^{86}$ Similarly, Danelski has questioned, ${ }^{87}$ why in the following term, in the famous case of Adkins $v$ Children's Hospital of the District of Columbia, did McKenna vote with the narrow five-justice majority to void the minimum wage law that was at issue in that case when just six years earlier McKenna himself had written the Court's majority opinion upholding the constitutionality of such statutes in the well known case of Bunting $v$ Oregon?

McKenna's mental incapacity apparently became even worse during the ensuing term of October 1923. Justice Holmes complained to a friend in early March of 1924 that his own opinion in one trademarks case "awaits the oscillations of McKenna to determine whether it shall be the judgment of the Court." The following month Chief Justice Taft polled his colleagues as to whether Justice McKenna should be expressly asked to retire. Five other justices agreed with Taft that he should, but when Justice Holmes was indecisive and Justice Brandeis answered no, Taft held back from taking action."

During the summer of 1924, Chief Justice Taft and Justice Willis Van Devanter visited McKenna's physician, Dr. Sterling Ruffin, and the doctor readily agreed that McKenna should retire. ${ }^{92}$ McKenna again resisted any such suggestion, however, and Taft reluctantly decided to wait until after the early November presidential election before taking further action. Then Taft and Van Devanter again conferred with McKenna's physician, "who concurred with us that his

86 Danelski, 54 Yale Rev at 414 (cited in note 37). See also McDevitt, Joseph McKenna at 130-53 (cited in note 80) (surveying McKenna's labor decisions and concluding that "the general tenor of McKenna's philosophy toward the laborer and laboring conditions might be recognized as sympathetic and progressive").

87 See Danelski, 54 Yale Rev at 415 (cited in note 37). See also McDevitt, Joseph McKenna at 228 (cited in note 80 ) (quoting a June 11, 1923 letter by William Howard Taft in which the Chief Justice called McKenna a "Cubist" whose case votes indicated that "he makes up his mind now on the impressionistic principle").

88261 US 525 (1923). October Term 1922 also witnessed the medically required retirement of Justice Mahlon Pitney, who had served for over ten years, but, being only sixty-four years old, required a special pension bill similar to those previously enacted for Justices Hunt and Moody. See Act of December 11, 1922, 42 Stat 1063. See also Walter F. Murphy, In His Own Image: Mr. Chief Justice Taft and Supreme Court Appointments, 1961 S Ct Rev 159,176-77.

89243 US 426 (1917).

90 Mark DeWolfe Howe, ed, 2 Holmes-Pollock Letters: The Correspondence of Mr. Justice Holmes and Sir Frederick Pollock 1874-1932 129 (Harvard 1941) (Holmes to Pollock, Mar 7, 1924). See also McDevitt, Joseph McKenna at 229 (cited in note 80). Justice Holmes appears to have been unduly pessimistic, for in the end, Holmes wrote in Prestonettes, Inc v Coty, 264 US 359 (1924), on behalf of an eight-justice majority, including Justice McKenna. Only Justice McReynolds dissented, and without opinion. Id at 369.

91 See Danelski, 54 Yale Rev at 416 (cited in note 37 ).

92 See id at 418.

93 See id at 419 (quoting Chief Justice Taft as telling Jacob M. Dickinson in an Oct 20,1924 letter that McKenna wanted to remain a Justice "because he does not know what he could do with his time if he were not on the bench. Undoubtedly he ought to retire."). 
mental grasp was by no means such as it had been, and that he was not able to do hard, sustained mental work."

Thus on November 9, Taft convened a conference at his home of all the justices except McKenna. Taft told his colleagues, as he recounted the meeting in a memorandum he prepared the following afternoon, that in his judgment Justice McKenna

had ceased to have the physical strength to command his mental energies for such a sustained effort as to make his opinions worthy of his own record or of the Court, and that it seemed to me unwise for us to decide any case in which there were four on one side and four on the other, with Mr. Justice McKenna's casting the deciding vote. This was agreed to by every one of the seven Associate Justices present [including the previously hesitant Holmes and Brandeis].

Taft then had Justice Van Devanter bring McKenna's adult son to Taft's home, and the Chief Justice informed the younger man of the message he would soon convey to his father. Even though Taft asked the son not to tell his father what was transpiring, he apparently did so, for early the next morning McKenna telephoned Taft and asked to come see him. When McKenna arrived, as Taft recounted in the memorandum he wrote later that day, "I told him that we had reached the conclusion that through a lack of physical strength he was not able to command his mental energies in such a way that he could do the work on the Court." Taft reminded McKenna how once in their Robing Room McKenna had said that he would not stay on the Court after he could no longer do the work, or after his colleagues concluded that he could not, and Taft told him "that we had reached the conclusion that that time had come because we did not think he could do the work."

McKenna disagreed, contending that he had written each and every opinion Taft had assigned him. "I told him then I had not as-

94 William Howard Taft, Untitled Confidential Memorandum-Nov 10, 1924, 1 (William Howard Taft Papers, Series 20, Manuscript Division, Library of Congress). I thank the always wonderfully helpful David Wigdor, Assistant Chief of the Manuscript Division, for sending me a copy of Chief Justice Taft's entire seven-page memo. See also Walter F. Murphy and C. Herman Pritchett, Courts, Judges, and Politics: An Introduction to the Judicial Process 217 (Random House 2d ed 1974) (reprinting the descriptive and highly detailed memorandum verbatim in its entirety). See also Murphy, $1961 \mathrm{~S} \mathrm{Ct} \mathrm{Rev}$ at 184-85 (cited in note 88).

95 Taft, Untitled Confidential Memorandum at 2 (cited in note 94). See also Murphy and Pritchett, Courts, Judges, and Politics at 218 (cited in note 94); Mason, William Howard Taft at 215 (cited in note 83).

96 Taft, Untitled Confidential Memorandum at 3-4 (cited in note 94). See also Murphy and Pritchett, Courts, Judges, and Politics at 218 (cited in note 94); Danelski, 54 Yale Rev at 421 (cited in note 37) (recounting the conversation between Taft and McKenna that led to McKenna's resignation). 
signed anything but the simplest cases to him and that even the opinions in those cases when returned by him had either to be reassigned or else had to be so changed, in order to meet the opinion of the Court, that it was quite evident he could not do the work." McKenna then finally acquiesced and agreed that "our opinion would control him." McKenna would retire in early January 1925, and Taft would assign him several last simple opinions. In his subsequent memorandum, Taft confessed that "[I] did not say to him, what of course is the fact, that for two years the situation has been such that we have felt it a violation of our duty not to speak earlier.,"98

Chief Justice Taft's explicit acknowledgment that the Court should have acted sooner than it did to secure McKenna's removal from the bench foreshadowed by less than five years a gentler decline in Taft's own mental acuity. From the outset of October Term 1929, even the seventy-two-year-old Taft himself acknowledged that he was slipping. "I am older and slower and less acute and more confused. However, as long as things continue as they are, and I am able to answer in my place, I must stay on the court in order to prevent the Bolsheviki from getting control." Ironically, Taft's insistence completely contradicted the argument for mandatory judicial retirement at age seventy that he himself had articulated sixteen years earlier in a well known book. In 1913, Taft had stated that

in a majority of cases when men come to be seventy, they have lost vigor, their minds are not as active, their senses not as acute.... In the public interest, therefore, it is better that we lose the services of the exceptions who are good Judges after they are seventy and avoid the presence on the Bench of men who are not able to keep up with the work, or to perform it satisfactorily. ${ }^{100}$

97 Taft, Untitled Confidential Memorandum at 4,5 (cited in note 94). See also Murphy and Pritchett, Courts, Judges, and Politics at 218 (cited in note 94).

98 Taft, Untitled Confidential Memorandum at 5 (cited in note 94). See also Murphy and Pritchett, Courts, Judges, and Politics at 219 (cited in note 94); Danelski, 54 Yale Rev at 421 (cited in note 37). McKenna's three final majority opinions, two handed down on December 15, and the last on January 5, 1925, were National Paper \& Type Co v Bowers, 266 US 373 (1924), Barclay \& Co $v$ Edwards, 267 US 442 (1924), and Davis v Manry, 266 US 401 (1925).

99 Henry F. Pringle, 2 The Life and Times of William Howard Taft 967 (Farrar \& Rinehart 1939) (quoting William Howard Taft to Horace D. Taft, Nov 14, 1929). See also Novick, Honorable Justice at 367 (cited in note 84 ) (quoting the letter as well).

100 William Howard Taft, Popular Government: Its Essence, Its Permanence and Its Perils 159 (Yale 1913). See also id at 160 (adding that "[w] hen most men reach seventy, they are loath thoroughly to investigate cases where such work involves real physical endurance"). Taft had noted that it was "doubtful whether Congress had any power to retire Judges," and that the absence of that power was a "defect" that could be remedied only by constitutional amendment. At least in 1913 Taft had not wanted to pursue any such course "because it would be dangerous in the present hysterical condition of many people" and might well result in justices serving elective terms rather than simply facing compulsory retirement. Id at 159,160 . See also Animated Discussion of 
By the time that William Howard Taft reached the age of seventytwo, the Chief Justice should have taken his own earlier advice, and Taft's biographer later acknowledged that by December of 1929, "the Chief Justice's mental deterioration became a matter of growing concern to his family." historical reputation, the Chief Justice resigned his position on February 3, 1930.

One of the saddest and most historically underappreciated instances of a Justice's increasing mental decrepitude prompting his colleagues to request his retirement occurred in January 1932, with Oliver Wendell Holmes, who by then was almost ninety-one years old. Back in 1910 Holmes had written to a friend about "the mistake that I have seen it to be in others to remain on the bench after seventy" years of age, ${ }^{102}$ but once Holmes reached his own ten year mark of High Court service in 1912, at age seventy-one, his occasional thoughts about retirement were replaced by the view that "I shall hold on unless something gives way." ${ }^{103}$ One of Holmes's sympathetic biographers has reported that the Justice "sometimes dozed" during the Court's conferences even as early as October Term $1928,{ }^{104}$ but by the late summer of 1931 Holmes found it harder and harder to write. ${ }^{105}$ Once the 1931 term commenced, Holmes was often visibly drowsy on the bench, ${ }^{106}$ and Chief Justice Hughes acknowledged that Holmes was "slipping. While he was still able to write clearly, it became evident in

the Age Limit for Judges, 6 NY L Rev 223 (1928); Extraordinary Interest in the Question of an Age Limit for Federal Judges, 6 NY L Rev 260-64 (1928) (documenting support among federal judges for a mandatory retirement provision based on age).

101 Mason, William Howard Taft at 294-95 (cited in note 83). See also Melvin I. Urofsky and David W. Levy, eds, "Half Brother, Half Son": The Letters of Louis D. Brandeis to Felix Frankfurter 431 (Oklahoma 1991) (Justice Brandeis writing Frankfurter on May 30, 1930 that "Taft for some time had really lost his grip").

102 Mark DeWolfe Howe, ed, 1 Holmes-Pollock Letters: The Correspondence of Mr Justice Holmes and Sir Frederick Pollock 1874-1932 167 (Harvard 1941) (quoting Holmes to Pollock, Sept 1,1910). Holmes had added that "I must remain till after I am 71 to get my pension," which vested only upon ten years of federal judicial service. Id.

103 Howe, 2 Holmes-Pollock Letters at 161 (cited in note 90) (quoting Holmes to Pollock, May 17, 1925). See also Howe, 1 Holmes-Pollock Letters at 172, 188, 190, 202 (cited in note 102) (Holmes on four occasions between December 1910 and September 1912 noting his December 1912 eligibility for retirement), and id at 205 (Holmes on Dec 15, 1912, having reached the ten year mark, telling Pollock that "I don't intend to hop off while I feel all right and believe that I am as good as ever").

104 See Novick, Honorable Justice at 367 (cited in note 84).

105 See id at 374

106 See Merlo J. Pusey, 2 Charles Evans Hughes 680 (Macmillan 1951); Merlo J. Pusey, The Court Copes With Disability, 1979 S Ct Hist Soc Yearbook 63, 68 ("On the bench, [Holmes] had great difficulty in keeping his head up and his eyes open."); Urofsky and Levy, Half Brother, Half Son at 469 (cited in note 101) (Justice Brandeis writing Felix Frankfurter on October 25, 1931 that Holmes "doesn't catçh on as he did at oral arguments"). 
the conferences of the Justices that he could no longer do his full share in the mastery of the work of the Court.",107

Hughes's biographer indicated that "Holmes' brethren began to fear that he would bring criticism upon the court,"10s and in early January 1932, as Hughes himself later recounted, "a majority of the Justices asked me to request him to resign. I consulted Justice Brandeis," Holmes's closest colleague, "who agreed that the time had come for Justice Holmes to retire and that I was the one who should take the matter up with him. The other Justices were of the same view. This was for me a highly disagreeable duty," 10,1932 , Hughes called on Holmes and articulated his message. "Justice Holmes received my suggestion, which was made as tactfully as possible, without the slightest indication of his resentment or opposition. At his request I got out from his bookshelves the applicable statute and he wrote out his resignation with his usual felicity of expression." "Thus even what may have been the single most distinguished career in the entire history of the United States Supreme Court ended in an explicitly requested retirement because of increasing mental decrepitude.

\section{THE NEW DEAL'S MISSED OPPORTUNITY}

Five years later, when President Franklin D. Roosevelt launched his "Court packing" assault on an institution whose consistently con-

107 Danelski and Tulchin, eds, The Autobiographical Notes of Charles Evans Hughes at 299 (cited in note 82).

108 Pusey, 2 Charles Evans Hughes at 680-81 (cited in note 106).

109 Danelski and Tulchin, eds, The Autobiographical Notes of Charles Evans Hughes at 299 (cited in note 82).

110 See Pusey, 2 Charles Evans Hughes at 681 (cited in note 106) (characterizing Hughes's visit as "a task he would never have undertaken on his own initiative"); Novick, Honorable Justice at 375 (cited in note 84); John S. Monagan, The Grand Panjandrum: Mellow Years of Justice Holmes 140 (University Press of America 1988). The dating of Hughes's visit to Holmes has created scholarly confusion. Pusey states that it occurred on Sunday, January 11, 1932. See Pusey, 2 Charles Evans Hughes at 681. G. Edward White asserts that it was Sunday, January 12, see G. Edward White, Justice Oliver Wendell Holmes: Law and the Inner Self 467 (Oxford 1993), but January 11,1932, was a Monday, and January 12,1932, was a Tuesday. Only former congressman John Monagan dates the visit precisely and correctly. Holmes's actual resignation letter, dated January 12 (and reprinted at 284 US vii), was indeed made public on January 12. See Holmes, 90, Quits the Supreme Court, NY Times 1, 3 (Jan 13,1932); Urofsky and Levy, Half Brother, Half Son at 472 (cited in note 101).

111 Danelski and Tulchin, eds, The Autobiographical Notes of Charles Evans Hughes at 299 (cited in note 82). See also Retirement of Mr. Justice Holmes, 284 US v, vii (1932) (reprinting Holmes's resignation letter); White, Justice Oliver Wendell Holmes at 467 (cited in note 110) (citing to a 1980 interview with H. Chapman Rose, who in January 1932 had been Justice Holmes's secretary, which persuasively contends that it was the young Mr. Rose, not the Chief Justice of the United States, who fetched the appropriate statute book from Holmes's shelf); Monagan, The Grand Panjandrum at 140 (cited in note 110) (quoting Rose); Novick, Honorable Justice at 482 n 47 (cited in note 84). 
servative judicial decisions had vitiated many of the New Deal's most important new programs, ${ }^{112}$ the age of the Court's Justices became a major public issue. Columnists Drew Pearson and Robert S. Allen had already successfully pinned the jurists with the less than flattering nickname of "The Nine Old Men," "13 and although six of the justices were older than seventy, that half-dozen included liberal icons Louis D. Brandeis and Benjamin N. Cardozo (plus Chief Justice Hughes) as well as the reactionary trio of Willis Van Devanter, James C. McReynolds, and George Sutherland. Partisan commentators like Pearson and Allen had asserted that the seventy-four-year-old Sutherland was "failing," but the ironic truth of the matter was that the Supreme Court in early 1937-unlike so many other times in the Court's previous history-actually did not include a single Justice against whom a case of mental decrepitude could be accurately lodged.

For over a year preceding Roosevelt's public announcement of his eventual "Court packing" proposal on February 5, 1937, the President's advisors had pondered whether to attack the ideological problem that the Court's conservative justices represented by means of a mandatory retirement measure. Attorney General Homer S. Cummings told Roosevelt in January 1936 that "[w]e might well be giving some serious thought to an amendment to the Constitution (should we find we are forced to that point) which would require the retirement of all Federal Judges, or, at least, all Supreme Court Judges, who have reached or who hereafter reach the age of seventy years." "Such an amendment," Cummings added, "would probably encounter less opposition than almost any other I can think of."115 Eleven months later, that same idea was championed publicly by Princeton University professor Edward S. Corwin, and Attorney General Cummings forwarded a copy of Corwin's writing to the president. ${ }^{116}$ Solicitor Gen-

112 See Michael Ariens, A Thrice-told Tale, Or Felix the Cat, 107 Harv L Rev 620, 625-27 (1994); Joseph Alsop and Turner Catledge, The 168 Days 7-10 (Doubleday 1938).

113 See Drew Pearson and Robert S. Allen, The Nine Old Men (Doubleday 1936). See also Robert S. Allen and Drew Pearson, More Merry-go-round 52 (Liveright 1932).

114 Pearson and Allen, The Nine Old Men at 159-60 (cited in note 113).

115 William E. Leuchtenburg, The Supreme Court Reborn:The Constitutional Revolution in the Age of Roosevelt 100-01 (Oxford 1995) (quoting Cummings to Roosevelt, Jan 29,1936). See also David E. Kyvig, Explicit and Authentic Acts: Amending the U.S. Constitution, 1776-1995 299 (Kansas 1996).

116 See Leuchtenburg, The Supreme Court Reborn at 101 (cited in note 115). See also id at 116 (quoting Corwin as saying that "[n]o reform could be better adopted than the requirement, to be laid down by an act of Congress, or, if necessary, by constitutional amendment, that no Judge may hold office under the United States beyond his seventieth birthday"). See also Edward S. Corwin, Court Should Make Only Unanimous Veto, Phil Rec 19 (Dec 4,1936) (the actual publication of the article of which Cummings had received an advance copy and from which he quoted). Corwin opined that mandatory retirement at age seventy "would tend to keep the court in touch with public sentiment, both by assuring a more rapid replacement of its members and by securing justices of younger and more flexible minds." Id. See also the four previous installments 
eral Stanley F. Reed was unimpressed, telling Corwin that "I wonder whether you over-emphasize the possibility of requiring retirement at seventy. It seems too small a thing to justify a constitutional amendment," ${ }^{117}$ but Cummings was strongly attracted to the idea. He told Corwin that "I have often thought that much was to be said for a constitutional amendment requiring retirements when the age of 70 is reached. I am wondering if there would be much opposition to such an amendment if it were so framed as not to affect the present judiciary by making it apply to future appointments only."118

But Roosevelt wanted to solve the problem that existed with the present Court, and he wanted to solve it in less time than ratification of a congressionally approved constitutional amendment by threefourths of the states would require. ${ }^{119}$ Thus, Roosevelt chose to call for enactment of a statute authorizing a president to name an additional justice, up to a maximum of six, for each sitting justice with over ten years of service who did not leave the Court within six months of attaining the age of seventy. ${ }^{120}$ Roosevelt's official message to Congress spoke passingly about "the question of aged or infirm judges," and contended that a "lowered mental or physical vigor leads men to avoid an examination of complicated and changed conditions," ${ }^{\text {,121 }}$ but

in Corwin's five-part series: Edward S. Corwin, Reform by Amendment Slow and Undemocratic, Phil Rec 1 (Nov 30, 1936); Edward S. Corwin, Constitution “As Is" Sustains New Deal, Phil Rec 5 (Dec 1, 1936); Edward S. Corwin, Theory of 'Finality' of Rulings Collapses, Phil Rec 12 (Dec 2, 1936); Edward S. Corwin, 4 Chief Proposals To Curtail Power, Phil Rec 19 (Dec 3,1936).

117 Leuchtenburg, The Supreme Court Reborn at 116 (cited in note 115) (quoting Reed to Corwin, Dec 3, 1936).

118 Id at 118 (quoting Cummings to Corwin, Dec 17, 1936).

119 See id at 110; Kyvig, Explicit and Authentic Acts at 302-06 (cited in note 115). See also Homer Cummings, Nature of the Amending Process, 6 Geo Wash L Rev 247, 258 (1938) (describing the process of amending the Constitution as "laborious" and "exceedingly slow").

120 See S 1392, 75th Cong, 1st Sess, in 81 Cong Rec S 956 (Feb 8, 1937); Arthur Krock, Roosevelt Asks Power to Reform Courts, Increasing the Supreme Bench to 15 Justices; Congress Startled, But Expected to Approve, NY Times 1 (Feb 6, 1937). See also Hughes Defended Judges Past 70, NY Times 9 (Feb 6, 1937) (noting how Chief Justice Charles Evans Hughes had in 1928 endorsed mandatory judicial retirement at age seventy-five rather than at seventy). One of Roosevelt's strategists and defenders, future Attorney General and future Justice Robert H. Jackson, later noted that any enlargement of the Court beyond nine "would have been avoided if those over seventy retired, which the message was something of an invitation to do." If Roosevelt's proposal had been enacted, Jackson thought, "[i]t probably would have resulted in retirement at seventy as a pretty consistent custom." Robert H. Jackson, The Struggle for Judicial Supremacy: A Study of a Crisis in American Power Politics 188 (Knopf 1941).

121 Franklin D. Roosevelt, To the Congress (Feb 5, 1937), in 6 The Public Papers and Addresses of Franklin D. Roosevelt: 1937 Volume: The Constitution Prevails 53, 55 (Macmillan 1941) (Samuel 1. Rosenman, Compiler and Collater). See also Reorganization of the Federal Judiciary, Hearings on S 1392 before the Senate Committee on the Judiciary, 75th Cong, 1st Sess, Part 1 at 4 (Mar 10, 1937) (Attorney General Homer Cummings likewise invoking "the problem of the aged or infirm judge"); Stephen R. Alton, Loyal Lieutenant, Able Advocate: The Role of Robert H. Jackson in Franklin D. Roosevelt's Battle With the Supreme Court, 5 Wm \& Mary Bill of Rights J $527,540-41$ (1997) (describing how Roosevelt's advisors recommended stressing "the advanced age of the current Justices"). In his testimony, Attorney General Cummings asserted that "[t]he 
neither the Administration nor its supporters in the press ever contended that any of the sitting justices were actually mentally decrepit. Roosevelt's plan, as well as his message, failed to acknowledge that the problem was the constitutional ideology, not the judicial capacity, of the Hughes Court's Justices.

Even before the President's measure was announced, however, House Judiciary Committee Chairman Hatton W. Sumners of Texas, who understood that two of the four most conservative justices, Willis Van Devanter and George Sutherland, were open to retiring under the right circumstances, had been quietly trying to avert a head-on collision. Sumners believed that a primary obstacle to Van Devanter's and Sutherland's departures lay in how a 1932 economy-ingovernment statute had halved former Justice Holmes's annual pension from $\$ 20,000$ per year to $\$ 10,000$. $^{123}$ That financial vulnerability was the happenstance result of how the existing federal judicial pension statute failed to acknowledge that former justices had "retired" rather than simply resigned from the federal bench. ${ }^{124}$ Representative Sumners successfully hurried a remedial statute through Congress, but politically his effort was of course "too late," even though Justice Van Devanter took advantage of the enhanced retirement protection as soon as October Term 1936 concluded. ${ }^{125}$

verdict of experience is nearly unanimous that some sort of action should be mandatory when judges reach a certain, definitely fixed, age" and noted that "[o]bligatory retirement might be provided by constitutional amendment." Id at 5 . He added that "it is doubtful, and, really, more than doubtful, whether Congress could fix such a limitation" by statute. Reorganization of the Federal Judiciary, Part 1 at 34 (Mar 10, 1937).

122 See Jackson, The Struggle for Judicial Supremacy at 190 (cited in note 120) (conceding that "[i]nstead of accusing some Justices of being stubbornly and wrongly reactionary, which the other Justices could hardly deny, the message in effect charged the Justices collectively with inefficiency and inadequate discharge of duty. The charge alienated Brandeis, oldest of the Justices."). See also Warner W. Gardner, Court Packing: The Drafting Recalled, 1990 J S Ct Hist 99, 100,102 (observing that "a constitutional confrontation that men could fight for became an exercise in Madison Avenue sleaze" and calling Attorney General Cummings's defense of Roosevelt's approach "a smoothly crafted bit of hokum"); Alpheus Thomas Mason, Harlan Fiske Stone: Pillar of the Law 443 (Viking 1956) (terming Roosevelt's argument "disingenuous"); Mason, 85 $\mathrm{U} \mathrm{Pa}$ L Rev at 673 (cited in note 42) (criticizing Roosevelt's "sophistry and sham about age and judicial inefficiency").

123 See Barry Cushman, Rethinking the New Deal Court: The Structure of a Constitutional Revolution 15 (Oxford 1998); White, Justice Oliver Wendell Holmes at 469 (cited in note 110); Alsop and Catledge, The 168 Days at 40-41 (cited in note 112); Paul A. Freund, Charles Evans Hughes as Chief Justice, 81 Harv L Rev 4, 23 n 64 (1967). See also Economy Act Costs Holmes $\$ 10,000$ a Year, NY Times 19 (Aug 14, 1932); Opposes Cut in Pay of Justice Holmes, NY Times 3 (Jan 22, 1933); Senate Restores \$20,000 Pay Of Former Justice Holmes, NY Times 21 (Feb 7,1933).

124 See Van Tassel, 142 U Pa L Rev at 396-99 (cited in note 59) (detailing the idiosyncratic distinction between retirement and resignation created by the Act of February 25, 1919, 40 Stat 1156, 1157); Retirement or Supersession of Federal Judges, 5 Const Rev 240, 240 (1921).

125 See Van Tassel, 142 U Pa L Rev at 398 \& n 302 (cited in note 59) (detailing the Act of March 1, 1937, 50 Stat 24); Alsop and Catledge, The 168 Days at 77-78, 208-09 (cited in note 112). See also Turner Catledge, Court Compromise Pressed as Opposition Increases; House Starts 
The history reflects that Roosevelt's proposal was in deep trouble, particularly because of liberal discomfort with its disingenuousness, ${ }^{126}$ even before opposition senators persuaded Chief Justice Hughes, with an important assist from Justice Brandeis, to submit to the Senate Judiciary Committee a factual and understated letter that utterly vitiated Roosevelt's misformulated attack on the Court. ${ }^{127}$ Two attentive journalists, whose 1938 book remains the richest and most detailed account of the "Court packing" crisis, concluded that the Chief Justice's letter revealed to everyone just how "utterly hollow" the president's professed criticisms were, ${ }^{128}$ and even Hughes himself later acknowledged that his missive had had "a devastating effect by destroying the specious contention" that the Justices needed help." When the Court just one week later reversed its own prior stance and upheld a minimum wage law, ${ }^{130}$ and then two weeks after that upheld the constitutionality of the Wagner Labor Relations Act, ${ }^{131}$ the judi-

Action Today, NY Times 1, 13 (Feb 10, 1937); Turner Catledge, Roosevelt Drives for Court Reform as Congress Waits, NY Times 1, 2 (Feb 12, 1937); Turner Catledge, Roosevelt Plans a Court Bill Tour, Washington Hears, NY Times 1, 4 (Feb 27, 1937) (noting Senate approval of Sumners's bill on February 26); Van Devanter, 78 Retires; Adverse Court Bill Report Voted by Committee, 10 to 8, NY Times 1 (May 19, 1937). Two years later, in the Act of August 5, 1939, 53 Stat 1204,1205, the Congress also authorized half-pay retirement for permanently disabled justices who had served for less than ten years. See Van Tassel, 142 U Pa L Rev at 402 (cited in note 59).

126 See Alsop and Catledge, The 168 Days at 55-59,76 (cited in note 112) (terming Roosevelt's approach "fantastically disingenuous" and criticizing "the President's substitution of sophistries for real arguments"). But see Leuchtenburg, The Supreme Court Reborn at 141 (cited in note 115) (contending unpersuasively that prior to the end of March, "it still seemed highly likely ... that FDR's proposal would be adopted").

127 See Cushman, Rethinking the New Deal Court at 17-18 (cited in note 123); William E. Leuchtenburg, The Nine Justices Respond to the 1937 Crisis, 1 J S Ct Hist 55, 58, 62-63 (1997); Richard D. Friedman, Chief Justice Hughes' Letter on Court-Packing, 1 J S Ct Hist 76, 79-80 (1997); Marian C. McKenna, Prelude to Tyranny: Wheeler, F.D.R., and the 1937 Court Fight, 62 Pac Hist Rev 405, 423-24 (1993); Danelski and Tulchin, eds, The Autobiographical Notes of Charles Evans Hughes at 304-06 (cited in note 82); Freund, 81 Harv L Rev at 27-29 (cited in note 123); Leonard Baker, Back to Back: The Duel between FDR and the Supreme Court 153-62 (Macmillan 1967); Burton K. Wheeler with Paul F. Healy, Yankee from the West: The Candid, Turbulent Life Story of the Yankee-born U.S. Senator from Montana 327-33 (Doubleday 1962); Alpheus Thomas Mason, Brandeis: A Free Man's Life 624-27 (Viking 1946); Mason, Harlan Fiske Stone at 450-52 (cited in note 122); Pusey, 2 Charles Evans Hughes at 754-56 (cited in note 106); Alsop and Catledge, The 168 Days at 124-27 (cited in note 112). See also Hughes Against Court Plan; Wheeler Says It Originated with "Young Men" Last Year, NY Times 1 (Mar 23, 1937). The Times printed the entire text of Chief Justice Hughes's letter, beginning at the very top of page one. Hughes's letter is also reprinted in the Judiciary Committee's ensuing adverse report on the Roosevelt proposal. See Reorganization of the Federal Judiciary, S Rep No 75-711, 75th Cong, 1st Sess 38-40 (June 14, 1937).

128 Alsop and Catledge, The 168 Days at 127 (cited in note 112). See also Freund, $81 \mathrm{Harv} \mathrm{L}$ Rev at 28-29 (cited in note 123); Baker, Back to Back at 159-60, 162 (cited in note 127).

129 Danelski and Tulchin, eds, The Autobiographical Notes of Charles Evans Hughes at 306 (cited in note 82).

130 See West Coast Hotel Co v Parrish, 300 US 379, 400 (1937), overruling Adkins v Children's Hospital of the District of Columbia, 261 US 525 (1923).

131 See NLRB v Jones \& Laughlin Steel Corp, 301 US 1, 49 (1937). See also Washington, 
cially imposed "death sentence" for the Roosevelt plan was all but complete. $^{\text {rs }}$

In between the public issuance of Hughes's letter on March 22 and the ensuing brace of remarkable Supreme Court decisions, however, public attention for a brief time focused on the possibility that a constitutional amendment mandating retirement of justices at age seventy-five might indeed emerge as a serious alternative to Roosevelt's plan. This aspect of the "Court packing" controversy has inexplicably gone unmentioned in all of the major, standard secondary accounts of the battle, ${ }^{133}$ but contemporary congressional records and newspaper stories detailed it prominently.

Ten days after President Roosevelt's initial bombshell announcement, Louisiana Democratic Senator Allen Ellender proposed a constitutional amendment requiring the retirement of all federal judges and justices at age seventy. ${ }^{134}$ Two days later, Nebraska Democratic Senator Edward R. Burke submitted one mandating compulsory retirement at age seventy-five. ${ }^{1.5}$ Burke's proposal drew decidedly more public attention than Ellender's, but early news reports stressed that given Roosevelt's insistence upon a quick statutory change, no constitutional amendment "is considered to have more than the slightest chance of adoption." ${ }^{136}$ In mid-March, Florida Democratic

Virginia \& Maryland Coach Co v NLRB,301 US 142, 147 (1937) (upholding NLRA as applied to businesses engaged in interstate passenger transport); Associated Press $v$ NLRB, 301 US 103, 133 (1937) (upholding NLRA as applied to the Associated Press); NLRB v Friedman-Harry Marks Clothing $C o, 301$ US 58,78 (1937) (upholding NLRA as applied to garment manufacture and citing Jones \& Laughlin); NLRB v Fruehauf Trailer Co, 301 US 49, 57 (1937) (upholding NLRA as applied to manufacture of trailers and citing Jones \& Laughlin).

132 See Alsop and Catledge, The 168 Days at 145 (cited in note 112). See also id at 163,197, 206, 229; Cushman, Rethinking the New Deal Court at 18-32 (cited in note 123).

133 See Leuchtenburg, The Supreme Court Reborn (cited in note 115); Cushman, Rethinking the New Deal Court (cited in note 123); Baker, Back to Back (cited in note 127); Alsop and Catledge, The 168 Days (cited in note 112).

134 See S J Res 77, 75th Cong, 1st Sess, in 81 Cong Rec S 1195 (Feb 15, 1937) (introduced by Senator Ellender). See also Fierce Congress Struggle Over Courts Indicated, NY Times 15 (Feb 11, 1937) (Senator Ellender stating that "I do not believe that Federal judges should be permitted to serve after they attain the age of 70 years, and $I$ favor an amendment of the Constitution to that effect"); Turner Catledge, Democrats Press Search For a Court Compromise, NY Times 1, 4 (Feb 16, 1937) (briefly noting Senator Ellender's proposal).

135 See Tenure and Composition of Certain Judges, S J Res 86, 75th Cong, 1st Sess, in 81 Cong Rec S 1273 (Feb 17, 1937) (introduced by Senator Burke). See also Turner Catledge, 2 Amendments Proposed to Limit Court's Power; A.F. of L. Backs President, NY Times 1 (Feb 18, 1937).

136 Catledge, 2 Amendments Proposed, NY Times at 1 (cited in note 135). See also Turner Catledge, Courts Plan Bolt Spurs Roosevelt to Intensify Drive, NY Times 1, 2 (Feb 19, 1937) (briefly noting Burke's proposal). Professor Freund reports that President Roosevelt rejected a direct suggestion by prominent New York lawyer C.C. Burlingham that a constitutional amendment mandating retirement at age seventy-five would be preferable, asserting that ratification of it by state legislatures might fail. See Freund, 81 Harv L Rev at 22 n 62 (cited in note 123) (citing Burlingham to Roosevelt, Feb 19,1937, and Roosevelt to Burlingham, Feb 23, 1937). 
Senator Charles O. Andrews had introduced a more complicated and far-reaching amendment that also incorporated mandatory retirement at age seventy-five, ${ }^{137}$ but none of the amendments had been at the center of legislative debate prior to the March 25 Senate Judiciary Committee testimony of Columbia University Law School Dean Young B. Smith. ${ }^{138}$ Dean Smith, a Roosevelt Democrat, voiced strong opposition to the President's plan but pointed out that a superior alternative approach was also available:

[A]n amendment to deal with the specific issue before this committee now can be drafted with ease, can be stated in simple language, and can be acted upon promptly. That would be an amendment fixing the tenure of the Justices by requiring them to retire at a specified age. Whether the age be fixed at 70 or $75, \mathrm{I}$ do not think is a matter of controlling importance, but I would prefer 75 . $^{13}$

137 See Constitutional Amendment Relating to the Judiciary, S J Res 100, 75th Cong, 1st Sess, in 81 Cong Rec S 2138 (Mar 12, 1937) (introduced by Senator Andrews). See also ElevenJustice Court Proposed, NY Times 11 (Mar 13, 1937) (briefly noting Andrews's proposal); Statement of Senator Andrews on Behalf of S J Res 100, 75th Cong, 1st Sess, in 81 Cong Rec S 2616, 2617 (Mar 23, 1937) (asserting that "there cannot be any serious doubt that 75 is a proper age for involuntary retirement" and contending that "where a Justice is fully competent after he reaches the age of 75 it is more or less an exception"). Also note H J Res 293, 75th Cong, 1st Sess, in 81 Cong Rec H 2731 (Mar 24, 1937) (introduced by Representative Bulwinkle of North Carolina) (joint resolution in part to provide for the retirement of all federal judges); H J Res 303, 75th Cong, 1st Sess, in 83 Cong Rec H 2933 (Mar 30, 1937) (introduced by Representative Case of South Dakota); H J Res 307, 75th Cong, 1st Sess, in 83 Cong Rec H 3057 (Apr 1, 1937) (introduced by Representative Daly of Pennsylvania). Other contemporaneous proposals included one introduced by Nebraska Independent Senator George W. Norris that would have restricted the tenure of all federal judges and justices to nine years. See Jane Perry Clark, Some Recent Proposals for Constitutional Amendment, 12 Wis L Rev 313, 320 (1937).

138 See Turner Catledge, Court Debate Looses Flood of Amendments, NY Times IV 10 (Mar 21,1937 ) (noting both the Burke and Ellender proposals). See also Reorganization of the Federal Judiciary, Hearings on $\mathrm{S} 1392$ before the Senate Committee on the Judiciary, 75th Cong, 1st Sess, Part 3 at 560 (Mar 23, 1937) (well known Columbia University professor Raymond Moley testifying that "I heartily favor an amendment that would provide for the retirement of judges at some fixed age"); id at 636 (Mar 24,1937) (Princeton University President H.W. Dodds testifying that "I think the retirement at 70 under full pay should be required").

139 Reorganization of the Federal Judiciary, Part 3 at 720 (Mar 25, 1937) (cited in note 138). Smith also told the Committee that "compulsory retirement at any age is impossible without a constitutional amendment." Id at 717. See also Young B. Smith, Statement on the Proposal Regarding the Supreme Court Before the Senate Judiciary Committee, 23 ABA J 261, 263 (1937) (reprinting Smith's prepared testimony); Aim to Pack Court, Declares Hoover, NY Times 6 (Feb 6, 1937) (reporting Dean Smith's earlier pronouncement that the Roosevelt plan was "not only unfortunate but dangerous"). On Dean Smith, see Julius Goebel, Jr., Young Berryman Smith, Dean of the Faculty of Law, Columbia University: 1927-1952, 53 Colum L Rev 151 (1953); Julius Goebel, Jr., et al, A History of the School of Law, Columbia University 253-55,303-05,309-10,378-80 (Columbia 1955); Young Smith, 70, of Columbia Dies, NY Times 21 (June 25, 1960); William C. Warren, In Memory of Young Berryman Smith (1889-1960), 60 Colum L Rev 763 (1960); William Twining, Karl Llewellyn and the Realist Movement 52-59, 103-04 (Oklahoma 1973); Laura Kalman, Legal Realism at Yale, 1927-1960 74-75 (North Carolina 1986). 
The Judiciary Committee Senators were clearly intrigued by Smith's proposal, and the witness readily opined that "if the President of the United States put his influence behind it it would be adopted.", Senator Burke told Smith that he would modify his own proposed amendment so as to bring it into full accord with Smith's views, ${ }^{\text {it1 }}$ and the next morning's New York Times gave Smith's testimony top of page one coverage. ${ }^{142}$ Times correspondent Turner Catledge reported that the possibility of a mandatory retirement amendment becoming a substitute for Roosevelt's plan had "assumed definite proportions" as a result of Senators' receptiveness to Dean Smith's recommendation. ${ }^{1.3}$ But Catledge emphasized that "the substitute proposal would have slight chance of final adoption unless it were supported by Mr. Roosevelt." ${ }^{144}$ The following day Catledge again reported on page one that Smith's suggestion had generated "the first new enthusiasm for an amendment,"145 but reiterated "the practically undeniable reality that no amendment could be substituted for the President's plan and put through Congress without the support of Mr. Roosevelt himself.,"146

At least one Democratic member of the House took up the call for a mandatory retirement amendment,$^{\text {th }}$ and ongoing advocacy of Senators Andrews's and Burke's constitutional amendments was supplemented by yet a third highly similar proposal, also incorporating mandatory retirement at age seventy-five, introduced by Democratic Senator William G. McAdoo of California. ${ }^{148}$ Notwithstanding the

140 Reorganization of the Federal Judiciary, Part 3 at 730 (Mar 25, 1937) (cited in note 138).

141. See id at 735. See also Texan Sees 'A King' by Court Change, NY Times 21 (Apr 13, 1937) (noting another such statement of intent by Senator Burke).

142 See Turner Catledge, Dean Smith Spurs Senators to Back Court Amendment, NY Times 1 (Mar 26, 1937).

143 Id.

144 Id.

145 Turner Catledge, Senators Backing Court Amendment Seek a Group Pact, NY Times 1 (Mar 27, 1937).

146 Id. See also Turner Catledge, Court Issues Cleared by the Nation's Debate, NY Times 6E (Apr 4, 1937) (again stating that "no amendment can be proposed by Congress and ratified by the States unless it is supported actively by the President").

147 See Remarks of Herbert S. Bigelow, 75th Cong, 1st Sess, in 81 Cong Rec H 3174-75 (Apr 6, 1937). See also Rebuff Plan to End Court Bill Hearing, NY Times 12 (Apr 7, 1937) (noting Representative Bigelow's remarks).

148 See S J Res 143, 75th Cong, 1st Sess, in 81 Cong Rec S 4224 (May 6, 1937) (introduced by Senator McAdoo); Ashurst Demands Court Bill "As Is," NY Times 12 (May 5, 1937) (noting Senator Andrews's continued advocacy of his amendment); 15-Member Court Backed By M'Adoo, NY Times 17 (May 7, 1937) (reporting Senator McAdoo's move); Turner Catledge, Report Brandeis and Van Devanter Will Quit in June, NY Times 1, 10 (May 11, 1937) (noting Senator Burke's proposed amendment). See also Reorganization of the Federal Judiciary, Hearings on S 1392 before the Senate Committee on the Judiciary, 75th Cong, 1st Sess, Part 4 at 952 (Apr 2,1937 ) (Chicago attorney Walter F. Dodd testifying in favor of mandatory judicial retirement at age seventy-five); id at 988 (Reverend Anson Phelps Stokes, Canon of Washington Cathedral and President of the Phelps Stokes Fund, testifying in favor of compulsory judicial retirement at seventy-five); id at 997 (Detroit attorney William S. McDowell advocating adoption of a constitu- 
widespread majority-party support for such a measure, however, President Roosevelt's insistent refusal to give any consideration whatsoever to supporting any constitutional amendment gradually brought all efforts to just as dead an end as Roosevelt's own "Court packing" plan already had reached. ${ }^{14}$

The aftermath of the Roosevelt initiative's political collapse did witness some ongoing law review discussion of the underlying question. Writing in the Harvard Law Review in early 1938, Charles Fairman detailed how the Supreme Court's own history showed that "[v]oluntary retirement, in any real sense, is very rare indeed." man argued that "retirement should be made compulsory at such an age as to give promise of a vigorous and effective judiciary," and recommended that "there should be a method for separating from his office a judge who has become prematurely disabled." "Fairman warned that "[w] here only the judge himself may act, the public interest is not adequately protected." 152

tional amendment "providing for retirement at 75"); Reorganization of the Federal Judiciary, Hearings on S 1392 before the Senate Committee on the Judiciary, 75th Cong, 1st Sess, Part 5 at 1139 (Apr 2, 1937) (Fordham Law School Dean Ignatius M. Wilkinson recommending a constitutional amendment compelling retirement at seventy-five); Reorganization of the Federal Judiciary, Hearings on S 1392 before the Senate Committee on the Judiciary, 75th Cong, 1st Sess, Part 6 at 1728-29 (Apr 21,1937) (John Marshall Law School of Chicago Dean Edward T. Lee endorsing a constitutional amendment mandating retirement at seventy-five); id at 1934 (reprinting a Mar 31, 1937 letter from Wesleyan University President James L. McConaughy advocating "compulsory retirement, presumably at 70, for Supreme Court Justices").

149 See Will Ask President to Yield on Court, NY Times 5 (May 12, 1937) (reporting that Roosevelt's Senate "lieutenants" prefer that he would accept a constitutional amendment mandating "compulsory retirement at 75"); Turner Catledge, Roosevelt Demands Fight for Court Change Continue; Says Nation Backs His Aims, NY Times 1 (July 16, 1937); Turner Catledge, Court Bill Drive Collapses; Foes to "Write Own Ticket"; Barkley Made Leader, 38-37, NY Times 1 (July 22,1937).

Even after the battle had ended, Senator Tom Connally, Democrat from Texas, introduced yet another proposed constitutional amendment that included a provision mandating compulsory retirement of justices at age seventy-five. See S J Res 217, 75th Cong, 1st Sess, in 81 Cong Rec S 9414-15 (Aug 20,1937). On that same day, Senator Andrews introduced a revised version of his own earlier S J Res 100, which again also provided for mandatory retirement at age seventy-five. 81 Cong Rec S 9416-17.

150 Fairman, 51 Harv L Rev at 430 (cited in note 42). Fairman added that "[i]t is abundantly clear that the tendency has been to remain too long, and that only in extreme instances has the Court itself put pressure upon one-of its members." Id at 435.

151 Id at 433. See also S J Res 14, 76th Cong, 1st Sess, in 84 Cong Rec $S 70$ (Jan 4, 1939) (introduced by Senator Andrews of Florida); The Constitutional Age Limit for Judges: Letters from Many Correspondents Discussing Judicial Retirement for Age, 72 US L Rev 257, 258 (1938) (reporting that a nonstatistical survey of leading New York state lawyers showed that "[a]n overwhelming majority of our correspondents favor a constitutional age retirement for judges"); Charles S. Collier, The Supreme Court and the Principle of Rotation in Office, 6 Geo Wash L Rev 401,419 (1938) (proposing a constitutional amendment establishing nonrenewable twelve-year terms for Supreme Court justices).

152 Fairman, 51 Harv L Rev at 440 (cited in note 42). 


\section{THE NEW DEAL COURT}

Throughout the entire New Deal era, over sixteen years passed following Justice Holmes's forced retirement in 1932 before another case of Supreme Court incapacity arose in 1948. Justice Frank Murphy, a former Attorney General, had been named to the bench by Roosevelt in 1940 and had become one of the Court's most dependable liberal votes. Murphy was hospitalized several times during 1946 and 1947 , and became excessively dependent on the sleeping pill Seconal. ${ }^{153}$ In the winter of 1947-48, the fifty-seven-year-old Murphy was consistently fatigued and was hospitalized for more than two months. Murphy continued to participate in the work of the Court, and consultations with a psychoanalyst appear to have improved his state of mind. ${ }^{\text {sit }}$ However, Murphy developed yet another physical dependency, this time to the painkiller Demerol, and by the time that he returned to the Court in February of 1948, some of his closest acquaintances were convinced that the Justice was regularly purchasing illegal drugs. ${ }^{\text {ss }}$

Murphy at first thought he was doing better during the summer of 1948, but he again was hospitalized, and his "dependence on drugs" meant that he was unable to return to Washington for October Term 1948 until early December. ${ }^{1.6}$ During his 1948 absence, as during his earlier hospitalizations, Murphy generally "deputized" fellow Justice Wiley Rutledge to cast his votes, but Murphy's most assiduous biographer, Sidney Fine, also reports that "[o]n at least one occasion Rutledge, [Justice Hugo L.] Black, and Murphy's clerk jointly decided what Murphy's votes should be."'15 Once Murphy did return to Washington, his secretary and his sister concluded that the Justice's drug problem was now such that he was illegally purchasing drugs approximately twice a day. ${ }^{1.8}$ Murphy managed to make it to the conclusion of October Term 1948 despite some undocumented rumors that either Chief Justice Fred M. Vinson and/or President Harry S. Truman believed he should resign, ${ }^{15}{ }^{\text {b }}$ but on July 19, 1949 he died. As Fine notes, during Murphy's two final terms, the justice authored just 18 of the Court's 224 majority opinions, plus 15 dissents and 3 concur-

\footnotetext{
153 Sidney Fine, 3 Frank Murphy: The Washington Years 481 (Michigan 1984).

154 Id.

155 See id.

156 Id at $481-82$.

157 Id at 483. See also J. Woodford Howard, Jr., Mr. Justice Murphy: A Political Biography 458-59 (Princeton 1968).

158 See Fine, 3 Frank Murphy at 482 (cited in note 153).

159 Id at 483.
} 
rences. ${ }^{1.0}$ More importantly, but perhaps much too charitably, Fine also contends that

[t] here is no indication that Murphy's excessive use of drugs during his last two terms on the Court materially affected his performance as a justice. None of the available evidence suggests that he behaved erratically in public during this period, and his decisions ... and his votes were entirely consistent with the pattern of his decisions and votes in the years immediately preceding. ${ }^{161}$

However, if Murphy's drug problem meant that any significant number of his votes were indeed being cast by some combination of his clerks and his colleagues, then Frank Murphy should have resigned from the United States Supreme Court at least one year prior to the time of his death.

\section{THE CAMPAign FOR A CONSTITUTIONAL AMENDMENT, 1946-1955}

David Atkinson makes no reference whatsoever to Justice Murphy's dependence upon illegally obtained drugs in his less than one page treatment of Murphy and never notes Sidney Fine's rich biography. ${ }^{162}$ Yet far and away the most startling omission in Leaving the Bench is not Atkinson's failure to provide important and illuminating details about any one or another of the Court's succession of mentally decrepit justices but the complete and utter absence of any reference whatsoever to a fascinatingly instructive constitutional reform campaign aimed at imposing mandatory retirement for Supreme Court justices at age seventy-five that the elite leadership of the American bar mounted between 1946 and $1955 .{ }^{163}$ Historical remembrance that this effort ever occurred appears to be almost wholly lacking from the entire post-1954 historiography of the Supreme Court, ${ }^{16}$ and ergo a

160 Id at 485.

161 Id at 482-83. But see Howard, Mr. Justice Murphy at 460 (cited in note 157) (asserting that Murphy's judicial "unpredictability increased" even though "[t]here is no evidence of senility or breakdown").

162 See Atkinson, Leaving the Bench at 119-20,216-17 (cited in note 1). Fine's book is nonetheless listed in Atkinson's bibliography. See id at 231.

163 Atkinson indicates only that former Justice Owen J. Roberts supported the idea of such an amendment. See id at 72. In a subsequent appearance on C-Span's "Booknotes" program, Atkinson further noted how Roberts "gave testimony before the Senate" concerning such an amendment. Booknotes Transcript 28 (Aug 22, 1999) (available in Lexis-Nexis News Library, Trans File).

164 But see Walter F. Murphy, Congress and the Court: A Case Study in the American Political Process 78 (Chicago 1962) (according the story a five-sentence summary account); Kyvig, Explicit and Authentic Acts at 337 (cited in note 115) (making a two-sentence reference to the endeavor). As best I (and a very assiduous research associate) have been able to discover, those 
brief recounting of the story, and an appreciation of its stunningly ironic denouement, merits exposition here.

The progenitor of the campaign for a constitutional amendment mandating retirement at age seventy-five was Edwin A. Falk, a New York native who graduated from the University of Pennsylvania in 1914 at age twenty and received his law degree from Columbia two years later. Following service as a naval ensign during World War I, Falk combined an active New York law practice with the authorship of a string of books on naval history issues. ${ }^{1.5}$ By 1946 Falk was a highly active and well known member of the Association of the Bar of the City of New York, and in the October issue of its Record, Falk published a ten-page article entitled In Time of Peace Prepare for War.

His title notwithstanding, Falk's subject was the Supreme Court, not post-war military preparedness, and Falk's starting point was his belief that sooner or later, another presidential or congressional assault on the independence of the Supreme Court, similar to what had happened in 1937, was bound to recur. What Falk had in mind was "plugging the loopholes in the Constitution's protection for the Supreme Court" by means of an amendment that would "fortify" the Court's independence and "prevent future assaults." ${ }^{\text {"167 }}$ Falk called for an "exhaustive study" to "find as many as possible of the loopholes," but his initial list of suggestions included a provision fixing the number of justices firmly at nine and a prohibition mandating the justices' exclusion from politics. In addition, "removal in cases of mental or physical incapacity should be rendered simpler." ${ }^{168}$ Falk also, however, suggested that perhaps the advent of each new presidential term should witness the mandatory retirement of the Court's two most senior justices, so that each chief executive would be assured at least two appointments. Falk stressed that "[t]his outline is, of course, merely suggestive. The important thing now is to start the ball rolling and, so far as possible, to keep its movement nonpartisan."

Two months later, New York City Bar Association President Harrison Tweed announced the creation of a new Special Committee on the Federal Courts to be chaired by none other than Edwin A. Falk. ${ }^{170}$

two books are the only secondary sources to make any mention of the campaign.

165 See Edwin A. Falk, From Perry to Pearl Harbor: The Struggle for Supremacy in the Pacific (Doubleday 1943); Edwin A. Falk, Togo and the Rise of Japanese Sea Power (Longmans 1936); Edwin A. Falk, Fighting Bob Evans (J. Cape \& H. Smith 1931). See also E.A. Falk, Attorney and Naval Author, NY Times 35 (Nov 15,1956) (obituary).

166 Edwin A. Falk, In Time of Peace Prepare for War, 1 Rec of the Assn of the Bar of the City of NY 245 (1946).

167 Id at $250,249$.

168 Id at 251 .

169 Id at 254.

170 See Association Activities, 2 Rec of the Assn of the Bar of the City of NY 1 (1947). See 
The committee held its first official meeting in January $1947,,^{17}$ and within a week of that date a parallel committee of the American Bar Association reported that it expected it would soon have before it several proposals that were being considered by the New York City Bar, including one

requiring the retirement of justices on reaching a certain age (75 years is suggested). The fixing of the proper age would doubtless involve a considerable study of the actual effect of longevity on the work of the justices. Perhaps by reason of strength it should be four score years. In that we cannot now express an opinion. ${ }^{12}$

The New York City Bar committee met again in February, ${ }^{173}$ and when the ABA committee assembled in early June 1947, it

heard a discussion [by Edwin Falk] with regard to possible constitutional amendments fixing the number of Justices of the Supreme Court at nine, making them ineligible to the office of President or Vice President of the United States, requiring their retirement on reaching the age of 75 years, and prohibiting them from performance of duties other than those of their judicial office. The committee was not ready to take any action with regard to these matters ${ }^{174}$

since Falk's own New York City bar committee had not yet officially endorsed them.

also Harrison Tweed, Annual Report of the President, 2 Rec of the Assn of the Bar of the City of NY 256, 271 (1947) (stating that the committee "was appointed as a result of the article" by Falk and that "[i]t was logical that the author should be selected for the chairmanship"); George Mar- tin, Causes and Conflicts: The Centennial History of the Association of the Bar of the City of New York, 1870-1970 248-65 (Houghton Mifflin 1970) (detailing the highly energetic manner in which Tweed's presidency re-enlivened the Association); Michael J. Powell, From Patrician to Professional Elite: The Transformation of the New York City Bar Association 60, 93-95 (Russell Sage 1988) (noting that the Tweed metamorphosis included the creation of several new substantive committees and establishment of the Record).

171 See Association Activities, 2 Rec of the Assn of the Bar of the City of NY at 7 (cited in note 170$)$.

172 Report of the Special Committee on the Judiciary, 72 Annual Rep ABA 411, 417 (1947). The ABA had of course been a leading organizational opponent of President Roosevelt's 1937 “Court packing" plan. See Ariens, 107 Harv L Rev at 630-31 (cited in note 112); Jerold S. Auerbach, Unequal Justice: Lawyers and Social Change in Modern America 195-98 (Oxford 1976); Baker, Back to Back at 85 (cited in note 127); Alsop and Catledge, The 168 Days at 178 (cited in note 112).

173 See The Calendar of the Association for February, 2 Rec of the Assn of the Bar of the City of NY 56, 57 (1947).

174 Report of the Special Committee on the Judiciary, 72 Annual Rep ABA 256, 261 (1947). See also Supreme Court of the US:Amendments of the Constitution Are Proposed, 34 ABA J 1, 3 (1948) (arguing that the ABA, not local or regional bar associations, should lead the charge); $R e$ port of the Special Committee on the Judiciary, Advance Program of the Seventieth Annual Meeting, ABA 106, 111 (1947). 
By September the New York City Bar was reporting that its committee had ratified specific proposals, ${ }^{175}$ and after what was termed "an animated debate and division," a meeting of the full Association approved a quartet of specific items in early December: the number of justices would be fixed at nine, mandatory retirement would take effect at the end of the Term during which a justice turned seventy-five, no justice would be eligible for the presidency or vice-presidency within five years of serving on the Court, and the Court's appellate jurisdiction would no longer be subject to statutory alteration. ${ }^{176} \mathrm{New}$ York City Bar opponents of the initiative apparently argued that "during this interlude of serenity the subject should not be stirred up," but Falk and his allies responded successfully by stressing the preferability "of taking action to safeguard the Court at a time when its independence is not imminently threatened rather than at the time when the next attack is launched." ${ }^{17}$

In January 1948 the parallel ABA committee approved the proposals, ${ }^{178}$ and the following month the ABA's House of Delegates added its ratification at the Association's mid-year meeting. ${ }^{177}$ But

175 See Tweed, 2 Rec of the Assn of the Bar of the City of NY at 271 (cited in note 170). Tweed added that the New York committee had been "in close contact" with its ABA partner in the hope that "it will concur in the conclusions of our Committee and lend the national support of the American Bar Association to the practical problem of securing adoption of the amendments to the Constitution." Id.

176 See Supreme Court of the US, 34 ABA J at 1 (cited in note 174); Association Activities, 3 Rec of the Assn of the Bar of the City of NY 1 (1948).

177 Supreme Court of the US, $34 \mathrm{ABA} \mathrm{J}$ at 2 (cited in note 174).

178 See Report of the Special Committee on the Judiciary, 73 Annual Rep ABA 408, 411-12 (1948). The Committee's early 1948 report articulated a clear position on the issue of mandatory retirement:

It goes without saying, moreover, though there have been some real and apparent exceptions, that the burdens of the office are such that they cannot be borne satisfactorily by men of great age. There is no particular virtue in selecting the age of seventy-five years as the time when retirement should be mandatory, [but] as the years increase, the limit of the judge's powers is approached.

However, the committee sounded somewhat less certain with regard to the larger question of amending the Constitution:

Of course, there is risk in amendment of the Constitution that Pandora's box may be opened and that evils that we know not of will fly out. It is believed, however, that in a period like the present, when there is no public attack upon the powers of the judiciary, the good sense of the people and their representatives in Congress and the state legislatures may be depended upon to protect the independence of the Supreme Court in the exercise of its constitutional functions by a reasonable provision as to its composition.

179 See Proceedings of the House of Delegates: February 23-24, 1948, 34 ABA J 339, 342 (1948). The account notes that former Georgia Governor John M. Slaton "spoke eloquently in opposition to Section 2 of the amendment on the ground that age and experience should not compel retirement of judges." See also Association Activities, 3 Rec of the Assn of the Bar of the City of NY 127, 133-34 (1948) (noting ABA committee approval of recommendations for an amendment to provide compulsory Supreme Court retirement); Proceedings of the House of Delegates, 73 Annual Rep ABA 339, 350 (1948) (noting ABA House of Delegates approval for a 
when the ABA committee then made several primarily cosmetic improvements in the resolution (including fixing mandatory retirement at age seventy-five, irrespective of the Court's terms), ${ }^{180}$ and represented the amended measure to the full House of Delegates at the ABA's Annual Meeting in early September 1948, the measure was voted down by a tally of fifty-two to forty-three and returned to the committee. ${ }^{181}$

The measure's proponents were undaunted, and in midDecember the New York City Bar committee sponsored a speech endorsing its proposals by retired Supreme Court Justice Owen J. Roberts. Justice Roberts's speech was published as the lead article in the very next month's American Bar Association Journal, and thereby gave the proposals far and away the widest publicity they had yet received. Regarding mandatory retirement at age seventy-five, Roberts called it "a wise provision. First of all, it will forestall the basis of the last attack on the Court, the extreme age of the justices, and the fact that superannuated old gentlemen hung on there long after their usefulness had ceased." ${ }^{123}$

Late in December 1948 the ABA committee, citing Justice Roberts's "forceful" speech, re-endorsed the existing proposals and sent them back to the ABA's House of Delegates. ${ }^{\text {sis }}$ At the mid-year meeting a month later, however, members who wanted to enlarge the measure to include other provisions, such as a requirement that new justices possess judicial experience, successfully argued that the recommendation be referred to the ABA's Standing Committee on Jurisprudence and Law Reform. ${ }^{155}$

That standing committee reviewed the various provisions, focusing much of its attention on the question of whether a proposed

recommendation to amend the Constitution to require mandatory retirement of Supreme Court justices).

180 See Report of the Special Committee on the Judiciary, 73 Annual Rep ABA 268, 271-72 (1948). See also Report of the Special Committee on the Judiciary, in Advance Program of the Seventy-first Annual Meeting, ABA at 93,94,96-97 (1948).

181 See Proceedings of the House of Delegates: September 6-9, 1948,34 ABA J 1069, 1073-74 (1948); Proceedings of the House of Delegates: September 6-9, 1948, 73 Annual Rep ABA 94, 107 (1948).

182 See Association Activities, 3 Rec of the Assn of the Bar of the City of NY 357, 360 (1948).

183 Owen J. Roberts, Now Is the Time: Fortifying the Supreme Court's Independence, 35 ABA J 1, 1-2 (1949). See also Frank W. Grinnell, Proposed Amendments to the Constitution: A Reply to Former Justice Roberts, 35 ABA J 648, 706 (1949) (agreeing with Roberts that the provision mandating retirement at age seventy-five is "a wise one").

184 See Report of the Special Committee on the Judiciary, 74 Annual Rep ABA 465, 467-68 (1949).

185 See Proceedings of the House of Delegates: January 31-February 1, 1949, 35 ABA J 247, 250 (1949); Proceedings of the House of Delegates, 74 Annual Rep ABA 381, 393 (1949) (noting that the referral motion passed by a vote of seventy to sixty-seven). 
amendment should indeed prohibit statutory alteration of the Court's appellate jurisdiction, ${ }^{156}$ but when it recommended the proposals to the House of Delegates in September 1949, the House rejected the appellate jurisdiction provision and sent the entire package back to the committee.

Once again the committee resolved to return its recommendations to the House of Delegates at its next meeting in late February of $1950,{ }^{188}$ and at that time the House officially approved both a proposed amendment fixing the size of the Court at nine and compelling retirement at age seventy-five ${ }^{189}$ and a separate proposal rendering individuals ineligible for the presidency or vice-presidency within five years of having served on the Court. ${ }^{19}$ The ABA's action was reported

186 See Report of the Standing Committee on Jurisprudence and Law Reform, 74 Annual Rep ABA 220, 222-23, 227-28 (1949); Report of the Standing Committee on Jurisprudence and Law Reform, in Advance Program of the Seventy-second Annual Meeting, ABA 76, 78-79, 82-84 (1949). The Committee also noted the introduction of HR 4225 in April 1949 by Representative L. Gary Clemente of New York, a bill providing for statutorily mandated retirement of all federal judges and justices at age seventy. See HR 4225,81st Cong, 1st Sess, in 95 Cong Rec H 4564 (Apr 13, 1949). The Committee observed that "[t]his seems to us too early for automatic retirement" and added that "[w]hile such retirement age might, perhaps, be provided for by legisiation rather than constitutional amendment, the committee feels that the limitation of membership and automatic retirement provisions should be combined, and that both should be given permanence as part of our Constitution." Id. See also Hughes, The Supreme Court at 74 (cited in note 3) (future Chief Justice Hughes observing in 1928 that "Congress could not provide constitutionally for the compulsory retirement of a judge during good behavior by fixing an age limit" statutorily); Should There Be an Age Limit for Federal Judges?, 6 NY L Rev 185, 185-86 (1928) (acknowledging that "it is probable that an age limit for compulsory retirement could only be established by constitutional amendment" and concluding that seventy-five "would be about right"). Clemente's bill never emerged from the House Judiciary Committee.

187 See Proceedings of the House of Delegates: September 5-8, 1949, 35 ABA J 947, 951 (1949); Proceedings of the House of Delegates, 74 Annual Rep ABA 101, 110 (1949) (reporting that the negative vote on the appellate jurisdiction provision was forty-five to forty-one). See also Robert P. Patterson, Annual Report of the President for 1948-1949, 4 Rec of the Assn of the Bar of the City of NY 211, 215 (1949).

188 See Association Activities, 4 Rec of the Assn of the Bar of the City of NY 313, 316 (1949).

189 See Proceedings of the House of Delegates: Mid-year Meeting, February 27-28, 1950, 36 ABA J 329, 339 (1950); Proceedings of the House of Delegates, 75 Annual Rep ABA 403, 430-31 (1950). The resolution as adopted declared that it was "the sense of the American Bar Association that the Congress should propose and the legislatures of the states should ratify an amendment to the Constitution of the United States of America as follows:

Section 1. The Supreme Court shall be composed of the Chief Justice of the United States and eight associate justices in regular active service.

Section 2. The Chief Justice of the United States and each associate justice of the Supreme Court shall cease to be an active member of that court when he shall have attained the age of seventy-five years, but shall become an inactive member of the court and receive all the emoluments of his office."

Proceedings of the House of Delegates: Mid-Year Meeting, February 27-28, 1950,36 ABA J at 339.

190 A third proposal regarding minimal qualifications for new justices was rejected and returned to committee. See Proceedings, $36 \mathrm{ABA} J$ at 340 (cited in note 189). 
in the New York Times, ${ }^{191}$ and the resolution itself called for the relevant $\mathrm{ABA}$ committees to actively pursue the introduction and adoption of just such a constitutional amendment, ${ }^{192}$ but over two years of quietude then ensued before the New York City Bar Association noted in May 1952 that its committee had "entertained at luncheon Senator John Marshall Butler of Maryland," a conservative Republican who had entered the Senate only in 1951 but who was a member of both the Judiciary Committee and its Subcommittee on Constitutional Amendments. Butler already had introduced a resolution proposing an amendment that would bar any sort of electoral candidacy within five years of any federal judicial service, ${ }^{194}$ but Butler had told the committee that he now would support its own "legislative program." In mid-May of 1952, without even a prefatory speech on the Senate floor or any other attendant publicity, Butler introduced a resolution detailing an amendment that would fix the Court's size at nine, mandate retirement at age seventy-five, and insulate the Court's appellate jurisdiction over constitutional cases from any congressional alteration. ${ }^{196}$ Four months later City Bar Association President Whitney North Seymour notified his members - without any reference to the quietly pending resolution-that Butler would introduce their measure in the upcoming Eighty-third Congress. ${ }^{197}$

On February 16, 1953, Senator Butler introduced Senate Joint Resolution 44, and this time he explained on the floor that its purpose was to "forestall future efforts by a President or a Congress seeking to nullify or impair the power of the judicial branch" and warning that "there always is the danger of a renewal, sooner or later, of the campaign against judicial independence." ${ }^{198}$ Butler's 1953 resolution in-

191 Bar for Retirement in High Court at 75, NY Times 8 (Mar 1,1950).

192 See Report of the Standing Committee on Jurisprudence and Law Reform, 75 Annual Rep ABA 466, 467 ("Further resolved, That the Committee on Jurisprudence and Law Reform, jointly with the Committee on the Federal Judiciary, be and hereby is directed to advocate the introduction and adoption of such an amendment to the United States Constitution by all appropriate means.").

193 Association Activities, 7 Rec of the Assn of the Bar of the City of NY 229, 230 (1952).

194 See S J Res 117, 82d Cong, 2d Sess, in 98 Cong Rec S 63 (Jan 10, 1952).

195 Association Activities, 7 Rec of the Assn of the Bar of the City of NY at 230 (cited in note 193).

196 S J Res 154, 82d Cong, 2d Sess, in 98 Cong Rec S 5084 (May 13, 1952).

197 See Whitney North Seymour, Annual Report of the President for 1951-1952,7 Rec of the Assn of the Bar of the City of NY 341, 345-46 (1952). With regard to Edwin Falk's Special Committee on the Federal Courts, Seymour added that "[o]ver the years the Committee has shown an unswerving devotion to its assignment, unaffected by neglect or fatigue of others." See also Harrison Tweed, Provisions of the Constitution Concerning the Supreme Court of the United States, 31 BU L Rev 1, 1-2, 46 (1951) (twice commending and citing to Falk's October 1946 article (cited in note 166)).

198 S J Res 44, 83d Cong, 1st Sess, in 99 Cong Rec S 1106 (Feb 15, 1953). See also Clement E. Vose, Conservatism By Amendment, 46 Yale Rev 176, 180 (1956) (contending that Butler's meas- 
cluded a provision protecting the Court's appellate jurisdiction (which the ABA recently had endorsed) in addition to mandating a ninemember bench, retirement at age seventy-five, and a five-year ban on justices' presidential and vice-presidential eligibility. ${ }^{199}$ An identical companion measure, House Joint Resolution 194, was soon introduced by Representative Edward T. Miller of Maryland, ${ }^{200}$ but not until early 1954 did Butler's measure receive a hearing before the Senate Subcommittee on Constitutional Amendments. In advance of the hearing, Albert E. Jenner, Jr., the chairman of the ABA's Jurisprudence and

ure reflected "antagonism toward 'strong' presidents").

Butler's 1952-1953 resolutions had several precursors that significantly pre-dated even the multiple proposals introduced in 1937 . Prior to 1870 , at least three separate measures setting a compulsory judicial retirement age had been introduced, but no legislative action appears to have been taken on any of them. On December 4, 1809 (11th Congress, 2d Session), Senator Pope of Kentucky introduced a resolution mandating judicial retirement at age sixty-five. On April 7, 1826 (19th Congress, 1st Session), Representative Eastman of New Hampshire introduced one specifying mandatory retirement at age seventy. The issue was also glancingly raised in a proposed amendment to a resolution during the second session of the Twenty-third Congress in 1835. Lastly, in 1869 (40th Congress, 3d Session), a Representative Ashley proposed both twenty-year terms and mandatory retirement at age seventy, saying that it was sad to see a Supreme Court with "one-third of its members sleeping upon the bench and dying with age." Herman V.Ames, The Proposed Amendments to the Constitution of the United States during the First Century of Its History 151, 329, 342, 346, 390 (Franklin 1896) (quoting Ashley from 1869 Cong Globe at 210). See also John R. Vile, Encyclopedia of Constitutional Amendments, Proposed Amendments, and Amending Issues, 1789-1995 ix, 172, 176 (1996) (describing proposals for amending the Constitution to impose age limits on the judiciary); Emily Field Van Tassel, Beverly Hudson Wirtz, and Peter Wonders, Why Judges Resign: Influences on Federal Judicial Service, 1789 to $199237-38$ (Federal Judicial Center 1993) (describing several nineteenth-century constitutional amendments to establish a mandatory retirement age); Daryl B. Harris, Proposed Amendments to the US Constitution: 99th-101st Congresses (1985-1990) 67 (1992); Richard Davis, Proposed Amendments to the Constitution of the United States of America Introduced in Congress from the 91st Congress, 1st Session, Through the 98th Congress, 2d Session; January 1969-December 1984303 (1985); US Congress, Senate, Library, Proposed Amendments to the Constitution of the United States of America Introduced in Congress from the 88th Congress, 1st Session Through the 90th Congress, $2 d$ Session; January 9, 1963, to January 3, 1969 (1969) (cataloguing proposed amendments); US Congress, Senate, Library, Proposed Amendments to the Constitution of the United States of America Introduced in Congress from the 69th Congress, $2 d$ Session Through the 87th Congress, $2 d$ Session; December 6, 1926, to January 3, 1963, S Doc No 163, 87th Cong, 2d Sess (1963) (same); Evan Haynes, The Selection and Tenure of Judges 26 (National Conference of Judicial Councils 1944) (noting over forty-two proposed amendments relating to selection and tenure of judges since 1889); Michael A. Musmanno, Proposed Amendments to the Constitution: A Monograph on the Resolutions Introduced in Congress Proposing Amendments to the Constitution of the United States of America 82-88, HR Doc No 551, 70th Cong, 2d Sess (1929) (cataloguing relevant proposed amendments). John R. Vile, Rewriting the United States Constitution: An Examination of Proposals from Reconstruction to the Present (Praeger 1991), is far more selective in its coverage than its subtitle suggests.

199 See Report of the Standing Committee on Jurisprudence and Law Reform, 78 Annual Rep ABA 235 (1953), and a separate, subsequent Report from the same committee at 78 Annual Rep ABA 149 (1953). See also Proceedings of the House of Delegates: Diamond Jubilee Meeting, Aug 23-28, 1953, 39 ABA J 1024, 1037 (1953).

200 See H J Res 194, 83d Cong, 1st Sess, in 99 Cong Rec H 1231 (Feb 18, 1953). See also Bethuel M. Webster, Report of the President 1952-1953, 8 Rec of the Assn of the Bar of the City of NY 325, 353 (1953). 
Law Reform Committee, along with three other leading lawyers and Senator Butler, called on United States Attorney General Herbert Brownell. "We are pleased to report," the ABA representatives informed their colleagues, "that we obtained a very favorable reaction from the Attorney General who, we believe, will assist with the Amendment at the proper time."201

Senator Butler was the first witness when the Senate subcommittee hearing opened on January 29, 1954. "At the present time," he told his colleagues, "the Supreme Court of the United States is surrounded by an aura of tranquility - certainly an appropriate climate in which to consider any proposal affecting its composition and jurisdiction." Butler was followed first by former Justice Roberts, then by American Law Institute (and former New York City Bar Association) President Harrison Tweed, and then by Albert Jenner of the ABA. Jenner explained that the proponents' goals included 'insur[ing] against physical or mental impairment of individual Justices attendant upon age,"203 and, upon prompting from Butler, Jenner detailed their December conversation with Attorney General Brownell. The Attorney General "stated that he favored these proposals," Jenner explained, but wanted mandatory retirement at age seventy-five to be extended to cover all federal judges, not just Supreme Court justices. ${ }^{204}$ Another ABA representative, Henry W. Nichols, added that he had discussed the proposed amendment with highly esteemed New Jersey Chief Justice Arthur T. Vanderbilt, who was "strongly in favor" of justices retiring at a given age and who personally was "in favor of the age of 70 rather than age 75. ${ }^{2005}$

Proof that the proponents had carefully done their political homework came in the form of an endorsement letter from North Dakota Bar president E.T. Conmy; North Dakota Republican Senator William L. Langer was chairman of both the Constitutional Amendments Subcommittee and the full Senate Judiciary Committee. ${ }^{206}$ Edwin Falk, speaking as one of three final witnesses, underscored how the age limit would "forestall the 'old men' criticism" and noted how

201 Report of the Standing Committee on Jurisprudence and Law Reform, 79 Annual Rep ABA 526, 530-31 (1954). The Committee added that since August 1953 it "has been extremely active" and "has had voluminous correspondence and numerous meetings with people of prominence concerning this proposed Constitutional Amendment." Id.

202 Composition and Jurisdiction of the Supreme Court, Hearing on S J Res 44 before a Subcommittee of the Committee on the Judiciary, 83rd Cong, 2d Sess 2 (Jan 29, 1954).

203 Id at 21.

204 Id at 23.

205 Id at 34.

206 Id at 34-35. 
the late Chief Justice Hughes had also supported mandatory retirement at seventy-five. ${ }^{207}$ No opposition voices were present to be heard.

Soon after the hearing, Falk submitted a letter to Senator Butler stating that the proponents almost certainly would accept compulsory retirement at age seventy-five for all federal judges, ${ }^{2 / 8}$ and by the time that the full Senate Judiciary Committee filed a unanimously affirmative report on the resolution with the Senate on March 24, the resolution had been amended and expanded accordingly. ${ }^{2 / P}$ Noting the attractiveness of judicial pensions, the committee nonetheless acknowledged that "ample retirement provisions do not represent sufficient inducement for retirement of Justices" and concluded that "continued active service by Justices over the age of 75 tends to weaken public respect for the Supreme Court.."210 The committee added that "[t]he age at which retirement is compulsory is not nearly so important as the proposition that there be an age at which retirement is compulsory.",211

Hardly six weeks after the Judiciary Committee's report was filed, Senate Joint Resolution 44 was called up on the Senate floor. Senator Butler cited Charles Evans Hughes's 1928 account of Justice Grier's and Justice Field's forced retirements, and engaged in a friendly colloquy with Louisiana Democrat Russell Long, ${ }^{212}$ but the following day the first voices in opposition were heard. At the behest of Michigan Republican Senator Homer Ferguson, Butler agreed to drop the five-year prohibition on presidential or vice-presidential candidacies and acknowledged that it had drawn a good deal of private opposition from Senators. ${ }^{213}$ But liberal Missouri Democrat Thomas C. Hennings, Jr., emphasizing that the proposed amendment had gotten virtually no public news attention, ${ }^{214}$ contended that neither the hearing record nor the committee report made a persuasive case for instituting mandatory retirement at age seventy-five. ${ }^{215}$ Hennings argued that the proposal "has not had the kind of thorough study and debate that all constitutional amendments should have, ${ }^{216}$ but Butler

207 Id at 36,38 .

208 See id at 37.

209 See Composition and Jurisdiction of the Supreme Court, S Rep No 1091, 83d Cong, 2d Sess 10 (Mar 24, 1954).

210 Id at 5 .

211 Id at 6 .

212 See Composition and Jurisdiction of the Supreme Court, S J Res 44, 83d Cong, 2d Sess, in 100 Cong Rec S 6255-60 (May 10, 1954) (remarks of Senators Butler and Long). See also Hughes, The Supreme Court at 75-76 (cited in note 3) (describing the retirement of Justices Grier and Field).

213 See Composition and Jurisdiction of the Supreme Court, 100 Cong Rec S 6340, 6345-46 (May 11, 1954).

214 Id at $S 6341$.

215 See id at $\mathrm{S} 6342$.

216 Id at $S 6343$. 
responded by citing the history of forced retirements and the extensive consideration the $\mathrm{ABA}$ had given the proposals. ${ }^{217}$ Hennings complained that only nine senators were on the floor for their exchange, but within minutes the resolution was put to a vote and passed by a tally of fifty-eight to nineteen (with nineteen absent and not voting), well more than the two-thirds margin needed for approval. Aside from Oregon independent Wayne Morse, all of the "no" votes were cast by Democratic senators, including Hubert $\mathrm{H}$. Humphrey of Minnesota, Mike Mansfield of Montana, Warren Magnuson of Washington, and John Pastore of Rhode Island. Forty-three Republicans and fifteen Democrats voted in favor, including John F. Kennedy of Massachusetts and Lyndon B. Johnson of Texas. ${ }^{218}$

Three days after the Senate approval, the New York Times published a cautionary editorial echoing Senator Hennings's concerns. The amendment had been approved with "virtually no notice by the American public. No matter how meritorious such an amendment may be-and in this case we think it is meritorious-this is not the right way for the Senate to pass upon a substantial change in the nation's fundamental law." ${ }^{219}$ Emphasizing that "an alteration of the Constitution is certainly something that deserves more attention than the Senate gave in this instance," the Times endorsed both the provision explicitly mandating a nine-justice Court, which it called the "most important" measure, as well as the appellate jurisdiction item. ${ }^{200}$ However, the paper added, "There may be more question as to whether it is desirable to write into the Constitution a specific age for compulsory retirement." 221

Both Edwin Falk and Leonard D. Adkins, another leading lawyer active in the effort, replied to the Times editorial with letters to the editor welcoming the endorsement and stressing how much discussion the particulars already had received within the organized bar. ${ }^{22}$ Adkins stated that it was "very important" that the House of Representatives also act on the proposed amendment during the current session

217 See id at S 6344.

218 See id at $S 6347$. News coverage of the floor passage noted that it took place with "unusual dispatch" following "fewer than four hours of debate." Clayton Knowles, Senate for Amending Constitution to Bar "Packing" of Supreme Court, NY Times 1, 19 (May 12, 1954). See also Murphy, Congress and the Court at 78 (cited in note 164) (observing that "[i]ronically, in light of the conflict the Court would soon engender, it was largely the liberals who opposed the amendment and conservatives who favored its adoption").

219 Guarding the Supreme Court, NY Times 22 (May 14, 1954).

220 Id.

221 Id.

222 See Edwin A. Falk, Integrity of Supreme Court, NY Times 30 (May 19, 1954); Leonard D. Adkins, Protecting Supreme Court, NY Times 14 (May 22, 1954). 
of Congress, ${ }^{23}$ and in late June a House Judiciary subcommittee accorded the proponents a one-day hearing.

Senator Butler testified first, explaining how the Senate had adopted Attorney General Brownell's suggestion that the mandatory retirement provision apply to all federal judges and how he had jettisoned the five-year ban regarding presidential and vice-presidential candidacies. "[R]ather than risk losing the whole amendment, I consented to having this section dropped," he revealed. ${ }^{25}$ Butler continued:

During the debate on the floor I was importuned by the leadership of the Republican Party to delete that section. I am certainly not at liberty to say how the President feels about anything, but I think the President felt that with that section in it the amendment will cause such a controversy in the States that the whole thing may be defeated, and he didn't want it to be defeated. ${ }^{226}$

223 Adkins, Protecting Supreme Court, NY Times at 14 (cited in note 222).

224 See Composition and Jurisdiction of the Supreme Court, Hearings Before Subcommittee No 4 of the Committee on the Judiciary, House of Representatives, 83d Cong, 2d Sess 3 (June 23, 1954).

225 Id at 4.

226 Id at 7. Although the amendment's proponents clearly had the support of Attorney General Brownell, President Dwight D. Eisenhower appears to have made no explicit endorsement of the amendment either publicly or privately. Two weeks after the House hearing, prominent New York attorney (and former Democratic Party presidential nominee) John W. Davis, who had argued the losing side in the recent Supreme Court decision Brown v Board of Education, 347 US 483 (1954), wrote to Eisenhower (whom he had actively supported in the 1952 presidential race) commending the amendment, $\mathrm{S} J$ Res 44.

The eighty-one-year-old Davis noted that the amendment was designed in part to "prevent the repetition" of "unhappy instances where judges failing to recognize their own infirmities due to age have outstayed their usefulness. The only safeguard against such occurrences in the future is by the amendment now proposed." Presidential appointments secretary Thomas E. Stephens noted on Davis's letter that he had discussed it with Eisenhower on July 6, "and as a result, advised Senator Butler that it was all right with the President if the Senator put this letter in the [Congressional] Record, provided he got permission" from Davis. Memorandum from John W. Davis to Dwight D. Eisenhower (June 29, 1954), in Dwight D. Eisenhower, Records as President, 1953-1961; White House Central Files, Official File, Box 371, "OF 100-A Supreme Court of the United States (1)." Stephens's note clearly indicates that Butler had been in contact with the White House about the amendment, but sheds insufficient light on the question of why Eisenhower's express support was not requested or made public.

On July 7, President Eisenhower replied to Davis, thanking him for his letter. Eisenhower noted that while the resolution, if passed by Congress, "will not come to me for signature, I find that the Attorney General definitely favors it." Eisenhower added that "both of us are just a bit amazed to find you in favor of a change in our Constitution," but "I hasten to agree that you give sound reasons for your attitude in this case." Eisenhower closed by saying "I hope that adjournment will not prevent final Congressional consideration of this amendment." Dwight $D$. Eisenhower to John W. Davis (July 7, 1954), in Dwight D. Eisenhower, Records as President, 1953-61; White House Central Files, Official File, Box 371, “OF 100-A Supreme Court of the United States (1)."

I owe my deepest thanks to Archivist Herbert L. Pankratz of the Dwight D. Eisenhower Presidential Library in Abilene, Kansas, for locating the Davis-Eisenhower correspondence. Mr. 
Addressing mandatory retirement, Butler explained that "[i]t is the consensus of authoritative opinion that some limit should be placed on service, and that the age of 75 strikes the happy medium between experience and senility." $\mathrm{He}$ added that "history has shown that some of the members of the Court have stayed longer than they should have stayed in the best interest of the people."2zs

Just as in the Senate hearing, the proponents' star witness was former Justice Owen J. Roberts. Roberts asserted that "[i]t has occurred again and again and again that ... men who were superannuated and really unfit for service clung to their offices and became in effect useless to the Court." ${ }^{29}$ Clearly at ease, Roberts recounted to the subcommittee his initial impression of the almost ninety-year-old Oliver Wendell Holmes when Roberts first joined the Court in 1930. "I thought him quite remarkable in conference and so on. But my colleagues said, 'You haven't seen anything. Justice Holmes has failed enormously. You don't know because you don't know how wonderful he was 8 or 10 years ago. He has failed.' He did fail. He fell asleep on the bench at times."230

Roberts's frankness did not stop there. He added that Justice Brandeis "held on longer than he wanted to" and that "Chief Justice Hughes tempered the wind to him in the assignment of cases in the later years, just as he did to Holmes." "231 Following Roberts, Albert Jenner, Edwin Falk, and Harrison Tweed detailed the backing the amendment had from the ABA and from such legal luminaries as former Attorney General William D. Mitchell, ${ }^{232}$ but the hearing testimony was not sufficient to move the resolution to the House floor. The House subcommittee endorsed the Senate's version while recommending that the five-year ban on presidential or vice-presidential candidacies be reinstated, but the full House Judiciary Committee

\footnotetext{
Pankratz reports that these two letters appear to be the only items concerning the amendment contained in Eisenhower Library files. In addition to reviewing the White House Central Files, "I also checked Eisenhower-Brownell correspondence, the indices to the Cabinet and Legislative Leaders Meetings, and the finding aid for and a few folders of correspondence in the Herbert Brownell Papers. I did not locate any additional references to this resolution in these files." Herbert L. Pankratz to David J. Garrow (Jan 3, 2000) (e-mail message). See also William H. Harbaugh, Lawyer's Lawyer: The Life of John W. Davis 433-34 (Oxford 1973) (describing Davis's support for Eisenhower as president).

227 Composition and Jurisdiction of the Supreme Court, Hearings Before Subcommittee No 4 at 4 (cited in note 224).

228 Id at 8.

229 Id at 20 . Roberts added that "a 75 -year retirement would work more of a rotation and give each President an opportunity to name somebody" to the Court. Id at 21.

230 Id at 24.

231 Id at 25.

232 Id at $32,37,38-39,40$.
} 
voted to table the resolution by what the ABA characterized as a "close" vote following "extensive debate."

The ABA activists informed the August 1954 annual meeting that the House Judiciary Committee might well have approved the resolution had the issue of the five-year ban not arisen, and the ABA's House of Delegates readily endorsed a recommendation deleting that provision from the proposed amendment after the ABA's own committee asserted there would be a "strong chance" for success in the House in the next Congress if that emendation were made. ${ }^{2.4}$ In the November elections, however, majority control of both the Senate and the House shifted from Republicans to Democrats, placing the amendment's strongest supporters in a decidedly weaker position than what they had enjoyed in the Eighty-third Congress. ${ }^{2.5}$ Senator Butler and Representative Miller each reintroduced the measure in the new Eighty-fourth Congress in February 1955, and a Senate hearing was initially scheduled for mid-July of 1955 , but the hearing was postponed and no further legislative action on the resolutions ever ensued.

What of course had most fundamentally changed between early May of 1954 and mid-July of 1955, above and beyond partisan control of the Congress, was that the previously uncontroversial political status of the United States Supreme Court had been utterly transformed by the burgeoning conflict kicked off by the Court's initial May 17, 1954, ruling in Brown v Board of Education. ${ }^{237}$ The Brown decision was most unpopular with the conservative congressional Democrats and Republicans who had formed the core of support for the bar associations' proposed amendment. Now, memories of the 1937

233 Report of the Standing Committee on Jurisprudence and Law Reform, 79 Annual Rep ABA 242, 244 (1954).

234 Id at 244. See also Proceedings of the House of Delegates: 77th Annual Meeting, $40 \mathrm{ABA}$ J 869, 908-09 (1954); Proceedings of the House of Delegates, 79 Annual Rep ABA 115, 144-45 (1954); Report of the Standing Committee on Jurisprudence and Law Reform, 80 Annual Rep ABA 428, 429 (1955).

235 See William S. White, Democrats Control House by 27; Apparently Will Rule Senate; President Pledges Cooperation, NY Times 1 (Nov 4, 1954); William S. White, Democrats Offer Harmony in Rule of 84th Congress, NY Times 1 (Nov 5, 1954) (confirming that Democrats had taken control of the Senate as well as the House). See also Duane Tananbaum, The Bricker Amendment Controversy: A Test of Eisenhower's Political Leadership 196 (Cornell 1988) (mentioning the ideological implications of the partisan turnover); Vose, 46 Yale Rev at 185 (cited in note 198) (underscoring the relative conservatism of the amendment's supporters).

236 See S J Res 45, 84th Cong, 1st Sess, in 101 Cong Rec S 1535 (Feb 15, 1955) (introduced by Senator Butler); H J Res 227,84th Cong, 1st Sess, in 101 Cong Rec H 1912 (Feb 22, 1955) (introduced by Representative Miller); Report of the Standing Committee on Jurisprudence and Law Reform, 80 Annual Rep ABA 254, 260 (1955). See also Edwin A. Falk, Integrity of Supreme Court, NY Times 22 (Jan 27, 1955); John R. Schmidhauser, The Butler Amendment: An Analysis by a Non-Lawyer, 43 ABA J 714 (1957); James C. Sheppard, Judicial Retirement: The Age of Judges and the Judge of Ages, 44 ABA J 145, 155 (1958) (advocating mandatory retirement at age sixty-five).

237347 US 483 (1954). 
Roosevelt attack upon the Court were quickly supplanted by anger at how new Chief Justice Earl Warren and his brethren appeared ready to upset America's political equilibrium. ${ }^{23}$ The Court's second ruling in Brown, in May of $1955,{ }^{239}$ did nothing to staunch the contentious atmosphere, ${ }^{240}$ but what most fundamentally altered congressional sentiment concerning the Court was not its desegregation holdings but the series of decisions negating various anti-Communism measures and investigations. Those began quietly with Quinn $v$ United States, ${ }^{241}$ Emspak v United States, ${ }^{242}$ and Peters v Hobby ${ }^{243}$ in May and June of 1955, then accelerated significantly with Pennsylvania v Nelson, ${ }^{24}$ Slochower $v$ Board of Higher Education of the City of New York, ${ }^{2+5}$ and Cole $v$ Young ${ }^{246}$ one year later,,$^{2,5}$ and finally peaked dramatically in May and June of $1957^{245}$ with a sextet of rulings in Schware $v$ Board of Bar Examiners of New Mexico, ${ }^{249}$ Konigsberg $v$ State Bar of Califor-

238 See Alexander M. Bickel, The Least Dangerous Branch: The Supreme Court at the Bar of Politics 75-77 (Yale 1962).

239349 US 294 (1955).

240 See Numan V. Bartley, The Rise of Massive Resistance: Race and Politics in the South During the 1950's 116-17 (LSU 1969) (describing the "Declaration of Constitutional Principles," better known as the "Southern Manifesto," issued by 101 members of Congress in March of 1956). See also Bickel, The Least Dangerous Branch at 256 (cited in note 238) (characterizing the Manifesto as "a calculated declaration of political war" against the Supreme Court).

241349 US 155 (1955).

242349 US 190 (1955).

243349 US 331 (1955).

244350 US 497 (1956).

245350 US 551 (1956).

246351 US 536 (1956).

247 See Murphy, Congress and the Court at 86-91 (cited in note 164) (describing the negative congressional reaction to the Warren Court's shift to the Ieft). See also the immediate attack mounted by former Justice James F. Byrnes, The Supreme Court Must Be Curbed, US News \& World Rep 50 (May 18, 1956), who as Governor of South Carolina had been a highly interested but not directly named party in one of Brown's companion cases, Briggs v Elliott, 347 US 483 (1954).

248 See C. Herman Pritchett, Congress Versus the Supreme Court, 1957-1960 3-5, 15-20 (Minnesota 1961) (noting the Court's rejection of congressional anti-communism measures); Murphy, Congress and the Court at 99-108,127-83 (cited in note 164) (describing the tide of liberal decisions issued by the Warren Court); Clifford M. Lytle, Congressional Response to Supreme Court Decisions in the Aftermath of the School Segregation Cases, 12 J Pub L 290 (1963) (describing the battle between the liberal Warren Court and the conservative, Southern members of Congress); Donald G. Morgan, Congress and the Constitution: A Study of Responsibility 26991 (Belknap 1966) (discussing congressional treatment of constitutional decisions throughout American history); Arthur J. Sabin, In Calmer Times: The Supreme Court and Red Monday (Pennsylvania 1999) (stating that "Red Monday" was the moniker anti-Communists gave to the Court's June 17, 1957 rulings).

249353 US 232 (1957). 
nia ${ }^{25,5}$ Jencks v United States, ${ }^{251}$ Watkins $v$ United States, ${ }^{252}$ Sweezy $v$ New Hampshire, ${ }^{253}$ and Yates $v$ United States. ${ }^{254}$

Most illustrative of how the ABA's congressional world was so completely upended by the Court's mid-1950s rulings was the utterly inverted stance of Maryland Senator John Marshall Butler toward the Court he had been so eager and enthusiastic to protect from congressional or executive encroachment in 1953 and 1954. Within just three years Butler was transformed into "an outspoken critic of the Warren Court," ${ }^{\text {,2s }}$ and in early 1958 Butler introduced a bill that would have removed from the Court's appellate jurisdiction bar admissions cases like Schware and Konigsberg-precisely the sort of legislative intrusion his 1953-54 constitutional amendment had been designed to prohibit. ${ }^{256}$ Butler's bill failed, but as Court scholar Walter Murphy noted several years later, the Maryland Senator "sorely regretted his earlier efforts to protect the Court's jurisdiction.,"27

\section{THE SUPREME COURT, 1956-1975}

Congress's failure to enact a constitutional amendment mandating compulsory retirement at age seventy-five of course brought the Court no respite from its recurring problem with mentally decrepit justices. Indeed, Senator Butler's measure had been dead for hardly six months before Justice Sherman Minton, a former Democratic Senator from Indiana whom his one-time congressional buddy Harry Truman had named to the Court in 1949, began to conclude that his mental powers were failing at the relatively young age of sixty-five. In late December 1955, Minton wrote to former President Truman to inform him that "I think I shall retire next fall. I am slipping fast. I have to carry a cane now all the time. I find my mental health keeps pace with my physical health. I find my work very difficult and I don't have the zest for the work that I used to have. So I am firmly convinced that

250353 US 252 (1957).

251353 US 657 (1957).

252354 US 178 (1957).

253354 US 234 (1957).

254354 US 298 (1957).

255 Murphy, Congress and the Court at $151 \mathrm{n}$ * (cited in note 164). See also Morgan, Congress and the Constitution at 272, 274-75, 279-87 (cited in note 248); Pritchett, Congress Versus the Supreme Court at 32,37,45-47,62,112 (cited in note 248); Murphy, Congress and the Court at 131, 141. On Senator Butler, see John M. Butler, 80; M'Carthy Supporter, NY Times sec 2 at 2 (Mar 17, 1978); Martin Weil, John M. Butler, Senator From Md. in 1950s, Dies, Wash Post C6 (Mar 17, 1978).

256 See Murphy, Congress and the Court at 165, 167-68 (cited in note 164) (noting Butler's introduction of a bill to remove "the Supreme Court's appellate jurisdiction only in state bar admission cases).

257 Id at 168. See also id at 195, 196, 207-08,211-12. 
I should retire."25s Minton knew that under the recently amended judicial retirement statute, he would need to wait until he had accumulated fifteen years of federal judicial service in order to retire at full salary at age sixty-five. ${ }^{2.9}$ His appeals court service, which had preceded his promotion to the Supreme Court, had commenced in October $1941,{ }^{20}$ and ergo Minton remained on the high bench for another ten months after confessing to Truman that he was "slipping fast." In May 1956, he privately told his brethren he would be leaving soon after October Term 1956 commenced, ${ }^{261}$ and in early June he selfpityingly told fellow Justice Felix Frankfurter that "[b]ut for my feeling of inadequacy and decrepitude and the embarrassment which comes from this deferential treatment accorded my 'senility' I would stay on.",262

Thirty-one years ago Professor Atkinson wrote his unpublished doctoral dissertation on Justice Minton, ${ }^{263}$ and his two-page treatment of Minton in Leaving the Bench draws on that earlier work. ${ }^{264}$ In an excerpt from his dissertation published in 1974, Atkinson detailed how during

his last term, [Minton] became persuaded his mental faculties were declining. He became exceedingly upset when, upon returning to his chambers, he could not remember what had been said only moments before in oral argument. He thus concluded that he was no longer able to perform on a level of competency which litigants before the Court had a right to expect. ${ }^{2 s}$

Leaving the Bench expressly attributes that information to one of Minton's October Term 1955 law clerks, ${ }^{26}$ and Atkinson, like other

258 William Franklin Radcliff, Sherman Minton: Indiana's Supreme Court Justice 173 (Guild 1996) (quoting Minton to Truman, Dec 27, 1955). See also Linda C. Gugin and James E. St. Clair, Sherman Minton: New Deal Senator, Cold War Justice 269 (Indiana Hist Soc 1997).

259 See Act of Feb 10, 1954, 68 Stat 8, 13. See also Gugin and St. Clair, New Deal Senator, Cold War Justice at 274 (cited in note 258) (discussing Minton's awareness of the retirement laws); Van Tassel, 142 U Pa L Rev at 398 (cited in note 59).

260 See Radcliff, Indiana's Supreme Court Justice at 109 (cited in note 258).

261 See Gugin and St. Clair, New Deal Senator, Cold War Justice at 273 (cited in note 258).

262 David N. Atkinson, Justice Sherman Minton and Behavior Patterns Inside the Supreme Court, $69 \mathrm{Nw}$ U L Rev 716, 720 (1974) (quoting Sherman Minton to Felix Frankfurter, June 4, 1956). See also Gugin and St. Clair, New Deal Senator, Cold War Justice at 284, 341 n 1 (cited in note 258) (also quoting the letter but dating it as June 9, 1956).

263 See David N. Atkinson, Mr. Justice Minton and the Supreme Court, 1949-1956 (unpublished Ph.D. dissertation, University of Iowa 1969).

264 See Atkinson, Leaving the Bench at 122-25 (cited in note 1). See also Atkinson, Mr. Justice Minton and the Supreme Court at 104-05,119 (cited in note 263).

265 Atkinson, $69 \mathrm{Nw}$ U L Rev at 736 (cited in note 262); Atkinson, Mr. Justice Minton and the Supreme Court at 119 (cited in note 263).

266 See Atkinson, Leaving the Bench at 122-24,217 n 88 (cited in note 1). See also Atkinson, 45 UMKC L Rev at 15 (cited in note 1). 
scholars, attributes Minton's decline to the effects of pernicious anemia. ${ }^{267}$ Minton announced his retirement in early September 1956 and officially stepped down from the bench on October $15 .^{268}$ Minton made no secret of his debilitation, and readily told Time magazine that his deterioration was not just physical. "Worst of all, it's gone to my brain. It affects my power to concentrate and think and retain arguments in my mind."

Following Justice Minton's retirement, the Supreme Court's next encounter with mental incapacity began within less than eight months. Justice Charles E. Whittaker joined the Court in late March of 1957 at the age of fifty-six, replacing retired Justice Stanley F. Reed. Whittaker previously had served for just nine months on the United States Court of Appeals for the Eighth Circuit, and before that he had served slightly less than two years as a United States District Judge in Kansas City. Whittaker years later told an interviewer that his district court service had been "a perfect delight" but that the "somewhat withdrawn" life of an appellate judge based in a city other than where his court was headquartered had made his Eighth Circuit experience "a rather drab existence." That writer concluded in 1972 that "Whittaker didn't feel overworked nor did there appear any signs of undue stress or physical breakdown" during his lower court service, ${ }^{m 2}$ but within literally the first ten weeks of Whittaker's arrival at the high Court, his brethren quickly realized that all was not well with their newest colleague. As Justice Harold $\mathrm{H}$. Burton wrote in his diary in mid-June 1957, "Justice Whittaker has been on the edge of a nervous breakdown but hopes to finish the term and then recuperate." 27

Only thirty years later, with the completion of a still-unpublished 1997 master's thesis by Craig Alan Smith, has a truly full depiction of Justice Whittaker's mental and emotional difficulties become available. $^{274}$ In an interview with Smith, Clyde J. Rayburn, Jr., who clerked

267 See Atkinson, Leaving the Bench at 122 (cited in note 1). See also Frances Howell Rudko, Truman's Court: A Study in Judicial Restraint 114, 125 n 21 (Greenwood 1988) (citing a 1983 interview with Minton's son Sherman A. Minton, a physician, regarding what Rudko terms the "depressing psychological effect" of Minton's pernicious anemia).

268 See Gugin and St. Clair, New Deal Senator, Cold War Justice at 276 (cited in note 258).

269 The Supreme Court, Time 31 (Sept 17,1956).

270 See Judith Cole, Mr. Justice Charles Evans Whittaker: A Case Study in Judicial Recruitment and Behavior 54, 60,73, 75 (unpublished M.A. thesis, Univ of Missouri-Kansas City 1972).

271 Id at 60, 73 (citing personal interviews with former Justice Whittaker in November 1970 and April 1971).

272 Id at 54.

273 Atkinson, 45 UMKC L Rev at 17 (cited in note 1) (quoting a Burton diary entry of June 18, 1957). See also Alan C. Kohn, Supreme Court Law Clerk, 1957-1958: A Reminiscence, 2 J S Ct Hist 40,47 (1998) (recalling that in the summer of 1957 Whittaker "was not just unhappy. He was distraught and in serious emotional distress.").

274 See Craig Alan Smith, Charles Evans Whittaker, Associate Justice of the Supreme Court (unpublished M.A. thesis, Univ of Missouri-Kansas City 1997). 
for Whittaker throughout Whittaker's years as a district and then circuit court judge, revealed that at the district court, Whittaker's longtime secretary, Celia Barrett, "informed other staff members that Whittaker had suffered previous 'breakdowns' at the Watson law firm" where he had practiced before ascending the bench. ${ }^{275}$ Smith's assiduous research unearthed evidence of "numerous incidents throughout his life when Whittaker suffered from anxiety and depression to the extent that it impaired his ability to work,"276 and Smith appropriately concludes that "Whittaker brought to the Supreme Court a serious medical condition that should have prevented his appointment." ${ }^{2 \pi}$

In a November 1970 interview, Whittaker recalled that an appointment to the United States Supreme Court is "one for which no man is fully prepared. No man knows what he is getting into when sent to that Court. The volume is tremendous, there is no suspension of the pressures. It is a day and night proposition which gets to be quite onerous." ${ }^{278}$ For Whittaker it became onerous almost immediately, and despite the optimistic cast of Justice Burton's June 1957 diary note, Whittaker told one clerk that he had thought of quitting the Court that first summer. "By the fall of 1957," Craig Smith discovered, Whittaker "was under the care of a Kansas City physician and taking medication to calm his nerves. His medications were mostly sedatives used to treat hypertension and insomnia." ${ }^{280}$ Once again, as in Kansas City, Whittaker's secretary, Celia Barrett, "confided to" his October Term 1957 clerks "that Whittaker had suffered previous nervous breakdowns as a lawyer. The other justices were unaware of this." 281

Whittaker made his work as a justice considerably harder for himself on account of an article he later remembered having read in US News \& World Report. An interviewer to whom he recounted the story said it had made "a deep impression" on Whittaker, for "[ $t$ ]he article, accusatory and strongly implying that it was really the clerks who wrote the opinions of the Court, totally firmed Whittaker's resolve that opinion writing was his function" and his alone. But the compo-

275 Id at 58.

276 Id at 30 .

277 Id at 76. See also Atkinson, Leaving the Bench at 130 (cited in note 1) ("Whittaker came to the Supreme Court with a preexisting medical condition that in later years would have precluded his appointment altogether.").

278 Cole, Mr. Justice Charles Evans Whittaker at 103 (cited in note 270).

279 See Smith, Charles Evans Whittaker at 102 (cited in note 274).

280 Id.

281 Id at 103.

282 Cole, Mr. Justice Charles Evans Whittaker at 119-20 (cited in note 270). Without much doubt, the article in question almost certainly was one written by a former clerk to Justice Rob- 
sitional burden was not Whittaker's only problem, for he sometimes was either uncertain how to vote on a particular case or indecisive about his choice once he had made it. He explained in a 1971 interview how

[a]fter a case is decided in the conference, those Justices not quite satisfied may go around to the chambers of another justice to express views and ... see if he can agree or must dissent ... [It is] not amiss to say that there is a good deal of politicking. For example in a four to four case, the one hold-out will be impleaded and beseeched ... by both sides. That's a very uncomfortable position to be in but [it] does happen with some frequency. ${ }^{230}$

For Whittaker it happened with greater frequency than for most justices, and in early 1958-at least according to the later recollections of William P. Rogers, who had succeeded Herbert Brownell as United States Attorney General-Whittaker twice phoned Rogers "complaining that he wanted to quit. Rogers refused to take Whittaker's complaint to the president; he convinced the justice to give the position more time.,284 Whether or not thanks to Rogers, Whittaker's attitude did gradually improve, ${ }^{255}$ and in October Term 1959 he even achieved the unusual success of privately "turning around" five of his colleagues who had voted differently from him at conference but who switched their votes and abandoned Justice Frankfurter's proposed majority opinion after they had read Whittaker's proposed dissent, which ended up speaking for a seven-justice majority.

ert $\mathrm{H}$. Jackson who himself later became an Associate Justice and then Chief Justice of the United States. See William H. Rehnquist, Who Writes Decisions of the Supreme Court?, US News \& World Rep 74 (Dec 13, 1957). A far less likely candidate, given Whittaker's recollection of the article's content, is The Bright Young Men Behind the Bench, US News \& World Rep 45 (July 12, 1957). See also David J. Garrow, "The Lowest Form of Animal Life"?: Supreme Court Clerks and Supreme Court History, 84 Comell L Rev 855, 869-70 (1999); William H. Rehnquist, Another View: Clerks Might "Influence" Some Actions, US News \& World Rep 116 (Feb 21, 1958); "Sway" of Clerks on Court Cited, NY Times 23 (Dec 10,1957) (an Associated Press news story reporting on publication of the Rehnquist article).

283 Cole, Mr. Justice Charles Evans Whittaker at 127 (cited in note 270). See also Kohn, 2 J S Ct Hist at 44-46 (cited in note 273) (detailing Whittaker's indecisiveness concerning Green v United States, 352 US 915 (1956) (granting certiorari), 354 US 935 (1957) (setting the case for reargument), 355 US 184 (1957) (reversing the decision below)).

284 David Alistair Yalof, Pursuit of Justices: Presidential Politics and the Selection of Supreme Court Nominees 64 (Chicago 1999) (citing a Jan 22, 1996 telephone interview with former Attorney General Rogers).

285 See Smith, Charles Evans Whittaker at 76 (cited in note 274) ("[A]fter two years he adjusted to the Court routine and even began to enjoy himself.").

286 See id at 123, 125; Cole, Mr. Justice Charles Evans Whittaker at 133-34 (cited in note 270). The case was Florida Lime and Avocado Growers, Inc v Jacobsen, 362 US 73 (1960). Judith Cole quotes an unnamed October Term 1959 Whittaker clerk as having told her that "[ $t$ ]his was a significant event on the Court, I believe. It was the first time he had taken some leadership and won over some people ... and beaten Frankfurter. In terms of his own personal feeling about his 
Craig Smith reports that by 1960 Whittaker, who previously had told friends he envisioned serving only five years on the high Court, was telling his clerks that he might stay for ten. ${ }^{257}$ One year later, however, during the winter of 1961-62, Whittaker's mental state took a very decided turn for the worse. Smith says that "Whittaker ceased to function effectively on the Court in early February, 1962."2ss Four weeks later, Smith writes:

Whittaker's anxiety and depression led him to contemplate suicide. It was early March 1962, and Whittaker was at his home in Washington. Although he did not attempt suicide, Whittaker was preparing to kill himself. His son, Keith, was at Whittaker's home, and he recalled clearly the incident when he prevented his father from committing suicide. It was a tense moment; father and son each looked the other in the eye, and Whittaker promised his son that he would not go through with it. Keith admitted frankly, "He would have killed himself if I had not been there to stop him."

A "few days" later, on March 6, Whittaker was admitted to Walter Reed Hospital." Smith says that Whittaker's "complete, unexpected physical and mental breakdown" was "not precipitated principally because of his dissatisfaction with his work, the pressures of deciding cases, or the infighting that occurred on the Court" but "principally because he suffered from acute anxiety, and the medications designed to control this condition complicated it with counteractive effects." ${ }^{211}$ Once admitted to Walter Reed, "Whittaker's doctors told him nothing was organically wrong with him," despite his ongoing problems with

job and his role and everything ... [it] made him feel good." The clerk added that "[i]t was a significant victory for him although not a significant case." Cole, Mr. Justice Charles Evans Whittaker at 134. Cole also quotes another unnamed and apparently earlier Whittaker clerk as noting that "Justice Whittaker was reluctant to disagree with Justice Frankfurter on any matter" and that "[h]is rapport with Felix Frankfurter was almost a teacher-student relationship." Id at $110,109$.

287 See Smith, Charles Evans Whittaker at 105 (cited in note 274).

288 Id at 107. See also Dennis J. Hutchinson, The Man Who Once Was Whizzer White: A Portrait of Justice Byron R. White 311 (Free Press 1998) (stating that Whittaker "had done no Court work since February 1"); Smith, Charles Evans Whittaker at 109 (cited in note 274) (quoting an Apr 25, 1962 memorandum by Chief Justice Earl Warren stating that "[w]e did not have the services of Charley since about February 1st"); John C. Jeffries, Jr., Justice Lewis F. Powell, Jr. 638 (Charles Scribner's Sons 1994) (citing a Feb 26, 1992 letter from George C. Freeman, Jr., a former October Term 1956 clerk for Justice Hugo L. Black, concerning how Black and Justice John M. Harlan in early 1962 had "decided to put over for reargument any case in which Justice Whittaker cast the deciding vote, but Whittaker resigned before any action was taken").

289 Smith, Charles Evans Whittaker at 105-06 (cited in note 274).

290 See id at 106. See also id at 111 (quoting a June 26, 1996 interview with October Term 1961 Whittaker clerk James N. Adler, who stated that "[w]e did not know he was ill. There was not much information about where he was or why he was out of the office.").

291 Id at $101,106$. 
"difficulty sleeping, loss of appetite, and difficulty concentrating." Whittaker's son Keith was a physician and Air Force captain, and Keith Whittaker later told Smith that "it was clear to me that the doctors had no decent treatment for his agitation. It was difficult to decide if he was so agitated because of the disease or the drugs they were giving him. I realized the drugs were causing his agitation."2033

Chief Justice Earl Warren visited Whittaker at Walter Reed on March 15, and "knew immediately that Whittaker was incapacitated and began steps to accomplish his formal retirement on grounds of disability." suaded him to retire," tice Tom C. Clark later told him that Chief Justice Warren "panicked when Whittaker admitted himself to the hospital." story, Whittaker "was apparently given no choice but to retire,"27 and indeed the very next day after Warren had visited him, a three-doctor board of Walter Reed physicians certified that Whittaker was suffering from a "permanent" medical disability and therefore recommended that he "be retired from the position of Associate Justice."

Whittaker left Walter Reed on March 23, but only on March 29 was his retirement publicly announced. Whittaker released a written statement saying that he had entered the hospital on account of "physical exhaustion from the great volume and continuous stresses of the Court's work" and that the doctors had concluded that any "return to the Court would unduly jeopardize my future health." moved back to Kansas City within three weeks of leaving the Court, and his son Kent later said "that it took the better part of a "year and a half" before Whittaker was able to "get back to normal." "Whittaker lived until 1973, and in a late 1971 conversation with some university students, the former Justice frankly acknowledged that he had left the Court because "he simply had a nervous breakdown.",

292 Id at 108.

293 Id.

294 Hutchinson, The Man Who Once Was Whizzer White at 312 (cited in note 288).

295 Smith, Charles Evans Whittaker at 76 (cited in note 274).

296 Id at 110.

297 Id.

298 Medical Board Proceedings Mar 16,1962, Earl Warren Papers, Box 358 (Manuscript Division, Library of Congress). I thank Professor Dennis J. Hutchinson of the University of Chicago for furnishing me with a copy of this and other Whittaker retirement documents from the Warren Papers.

299 Statement of Charles E. Whittaker, Associate Justice of the United States Supreme Court, 29 March 1962, in Earl Warren Papers, Box 358 (cited in note 298). See also Anthony Lewis, Ailing Justice Whittaker Leaving Supreme Court, NY Times 1 (Mar 30, 1962).

300 Cole, Mr. Justice Charles Evans Whittaker at 157 (cited in note 270); Smith, Charles Evans Whittaker at 147 (cited in note 274) (discussing Whittaker's transition off the Court).

301 Cole, Mr. Justice Charles Evans Whittaker at 156 (cited in note 270). See also Smith, Charles Evans Whittaker at 169 (cited in note 274). 
Justice Whittaker's mental or emotional incapacity does not appear to have altered any of his actual votes or influenced the outcome of any argued cases, but it posed an extremely serious threat to the Court that only Chief Justice Warren's aggressive intercession had eliminated so speedily. Four years after Whittaker's retirement, on the occasion of Warren's own seventy-fifth birthday, Warren told reporters that he was "not at all averse to a compulsory retirement date" for justices but then almost playfully added that for "many years" he had believed that mandatory retirement "would be a good thing" for "all public officials," including those in the legislative and executive branches. $^{302}$

After Whittaker, however, only seven years passed before the Court in 1969 was confronted with its next instance of mental incapacity in the person of eighty-three-year-old senior Associate Justice Hugo L. Black. Biographer Roger K. Newman has reported that even by 1966 Black's memory was beginning to fail. "Court work is harder now," Newman quotes Black as telling a former clerk in September 1967. "My mind isn't as quick." Newman adds, without citing a source, that "several times" toward the end of October Term 1967 Justice William O. Douglas "noted that in conference 'Black made unexpected remarks that don't make any sense.",304 Newman says that the mental decline affected "Black's ability to reason by analogy" and cites several 1967-68 instances of what he calls Black's "bizarre" onthe-bench behavior.

But Black's mental condition worsened significantly following a small stroke on July 18, 1969. Black's wife Elizabeth wrote in her diary that after it "he had lapses in his memory" and that five days later, when his clerk Kenneth Bass brought a request for a stay order to Black's home, Black's reaction was worrisome. "Ordinarily, Hugo would have known immediately what he wanted to do. However, with his impaired memory, he questioned Ken for two hours, often repeating questions Ken had already answered." Elizabeth Black concluded that her husband "has his intelligence but not his memory. It made me realize more fully that I do not want him to remain on the Court if he has less than his whole mentality.",307 1966).

302 John MacKenzie, Warren Is 75 Today, Plans to Stay on Court, Wash Post 6 (Mar 19,

303 Roger K. Newman, Hugo Black: A Biography 589 (Pantheon 1994).

304 Id.

305 Id.

306 Id at 595.

307 Elizabeth S. Black, Mr. Justice and Mrs. Black: The Memoirs of Hugo L. Black and Elizabeth Black 226-27 (Random House 1986). See also Newman, Hugo Black: A Biography at 597 (cited in note 303) (stating that the stroke caused "a partial loss of memory"); Bob Woodward and Scott Armstrong, The Brethren: Inside the Supreme Court 37 (Simon and Schuster 1979) 
Elizabeth Black wrote in her diary that "Hugo himself seems not to realize that his mentality has been impaired," but indicated at the end of July that her husband was considering retirement. ${ }^{3 i 8}$ A week later Mrs. Black wrote that "I have the gnawing conviction that Hugo must get off the Court," and in late September she noted that his ability to recall details remained "a little bit scrambled." Black nonetheless was in his seat when October Term 1969 commenced, but one retrospective account of October Term 1969 later reported that Black's ongoing "memory problems cropped up at unpredictable times." At the end of the term in June 1970 Elizabeth Black renewed her efforts to persuade her husband to retire, ${ }^{3 n}$ but Black wanted to surpass the record length of Supreme Court service that Justice Stephen J. Field had set during the 1890 s and ergo remained on the bench when October Term 1970 commenced. $^{312}$ In February 1971 Black turned eightyfive years old, and biographer Newman acknowledges that "[a]t times his memory, focus and sharpness were all seemingly gone. . . . He found it more difficult to concentrate. His short-term memory was waning." ${ }^{313}$ Another account focusing on early 1971 concludes that "Black began to stumble badly in conference. He would become tired and confused, unable to remember which case they were on. He bitterly rejected [Chief Justice] Burger's suggestion, however, that the conferences end a bit earlier to accommodate him.","314

In earlier years, Black had told former clerks that "[o]ne of the hardest things you have to do up here ... is to know when to leave. If you stay too long, you impose terrible burdens on your colleagues." 315 But just as with William Howard Taft forty years earlier, Black by 1971 was no longer willing or able to follow his own previous advice. Biographer Newman reports that by the summer of 1971, Black was outspokenly paranoid about the danger he imagined the United States faced from a military coup. Finally, on September 17, 1971, Black retired from the Supreme Court six months short of overtaking Stephen

(noting that Black in August 1969 "had trouble remembering things that had just happened").

308 Black, Mr. Justice and Mrs. Black at 227, 229 (cited in note 307).

309 Id at 229, 230.

310 Woodward and Armstrong, The Brethren at 77 (cited in note 307).

311 See Black, Mr. Justice and Mrs. Black at 243-44 (cited in note 307).

312 See Newman, Hugo Black: A Biography at 619-20 (cited in note 303). Black would have overtaken Field's record only in early March of 1972.

313 Id at 603, 604

314 Woodward and Armstrong, The Brethren at 124 (cited in note 307). See also Newman, Hugo Black: $A$ Biography at 604 (cited in note 303) ("In conference he began to stumble badly, becoming tired and confused, and unable to remember which case was being discussed. But he bitterly rejected Burger's suggestion that the conferences end a little earlier to accommodate him.").

315 Newman, Hugo Black: A Biography at 619 (cited in note 303) (quoting former Black clerk George C. Freeman, Jr.). 
J. Field's record. Just eight days later, on September 25, Hugo Black died. $^{316}$

Less than four years after Black's retirement, a far more public crisis confronted the Court after seventy-six-year-old senior Associate Justice William O. Douglas suffered a serious stroke on December 31, 1974. ${ }^{317}$ At conference on January 6, 1975, his colleagues decided to postpone oral arguments in five cases likely to generate closely divided votes until later in the term, but Douglas's absence from the bench continued until the final week of March. ${ }^{318}$ Douglas's first day back was March 24, and the next morning he met with reporters. The account of the meeting that appeared in the New York Times was not encouraging. Douglas acknowledged that he was confined to a wheelchair and that "there is not the same energy I had beforehand," but he declared that "[w]alking has very little to do with the work of the court" and insisted that the question of retirement had "never entered my mind." ${ }^{319} \mathrm{He}$ asserted that he would listen to tapes of all the oral arguments he had missed and would cast his vote in each and every case, but the reporters were clearly doubtful. John P. MacKenzie of the Washington Post termed Douglas's voice "weak" and noted that "at one point there was an embarrassing silence during which a reporter's question went unanswered." thin-faced," the Times's story stated that "[h] is voice was high, and it slurred once or twice." The Times's reporter described Douglas as "a frail and fragile old man, his voice thin and uncertain, his left arm hanging useless at his side, most of the once remarkable vigor ... drained away.",21

Douglas returned to the hospital on April 10, and two weeks later a story in the Times recounted how "[r]eports have recurred that Justice Douglas, during the three weeks that he was out of the hospital, became confused at times about his surroundings at the Court." ${ }^{, 32}$ The Times's account intimated that reporters were not being told the full truth about Douglas's condition, and a subsequent description of

316 See id at 620-21. See also Black, Mr. Justice and Mrs. Black at 269-79 (cited in note 307).

317 See Warren Weaver, Jr., Justice Douglas Suffers Stroke, NY Times 24 (Jan 2, 1975).

318 See Woodward and Armsttong, The Brethren at 357 (cited in note 307); Lawrence K. Altman, Court Spokesman Says Douglas Has Improved and Is Exercising, NY Times 24 (Jan 4, 1975); Warren Weaver, Jr., Douglas On Mend and Keeps Busy, NY Times 34 (Jan 31, 1975).

319 Douglas Firm About Staying on Court, NY Times 24 (Mar 26, 1975).

320 John P. MacKenzie, Douglas Vows to Stay on Job, Wash Post A4 (Mar 26, 1975).

321 Douglas Firm About Staying on Court, NY Times at 24 (cited in note 319). See also MacKenzie, Douglas Vows to Stay on Job, Wash Post at A4 (cited in note 320) (also characterizing Douglas as "frail"); James F. Simon, Independent Journey: The Life of William O. Douglas 447-48 (Harper \& Row 1980).

322 Warren Weaver, Jr., Douglas and the Court, NY Times 10 (Apr 25, 1975). See also Woodward and Armstrong, The Brethren at 362, 469 (cited in note 307) (reporting that Douglas attended one day of oral argument on April 21,1975, before returning to another hospital). 
Douglas's deportment during those weeks concluded that there was no doubt that "Douglas's mental condition [had] deteriorated. He repeatedly addressed people at the Court by their wrong names, often uttered nonsequiturs in conversation or simply stopped speaking altogether.",233

October Term 1974 concluded without Douglas returning to the bench and without any newly argued cases being decided in which Douglas's vote was decisive for a narrow majority. Indeed, at term's end the Court carried eight already argued cases over to the following term, and a Times story explicitly highlighted how the Court's press office refused to challenge the overwhelming evidence that Douglas's colleagues had privately agreed to hand down no cases in which Douglas's vote would determine the outcome. ${ }^{324}$ A subsequent account quoted an unnamed justice as acknowledging that such an agreement even precluded Douglas from casting determinative votes on petitions for certiorari:

Bill's votes were inconsistent with his prior positions. For example, he would vote to deny cert in cases where the issues were similar to earlier cases in which he had consistently voted to grant cert. So the purpose of the agreement was to protect Bill as well as the integrity of the Court.

The Times stated that whether Douglas would be able to return to the Court at the beginning of October Term 1975 was "in serious doubt, ${ }^{326}$ and those doubts increased even further after Douglas in mid-September of 1975 attempted to conduct a single-justice hearing on an application for a stay at the federal courthouse in Yakima, Washington, close to his summer home in Goose Prairie. A New York Times story describing the hearing stated that "[t]here were some tense and embarrassing moments," such as when Douglas at 1:00 p.m. announced that there would be a lunch break at 12:30 p.m. But when the attorneys' arguments in front of Douglas concluded, only a prolonged silence ensued. "Douglas sat motionless for 10 minutes without speaking, staring at a piece of paper, while spectators exchanged anx-

323 Simon, Independent Journey at 448-49 (cited in note 321).

324 See Warren Weaver, Jr., Douglas's Future on Court Assayed, NY Times 17 (July 8, 1975). See also Simon, Independent Journey at 449 (cited in note 321) (describing how "the other members of the Court agreed informally to a strategy that would effectively nullify [Douglas's] vote"); Woodward and Armstrong, The Brethren at 367-68 (cited in note 307) (describing the process by which the Court treated 5-4 decisions with Douglas in the majority as 4-4 ties); Lucy Howard with Diane Camper, Douglas the Durable, Newsweek 46 (July 7,1975) (noting that the Court scheduled cases for reargument and citing Douglas's absence as "[o]ne possible explanation").

325 Simon, Independent Journey at 449 (cited in note 321).

326 Weaver, Douglas's Future, NY Times at 17 (cited in note 324). 
ious glances.. ${ }^{327}$ Douglas eventually announced that he would grant the stay, which the full Court summarily vacated just four weeks later ${ }^{323}$ but the hearing left little doubt that Douglas was "a Justice who was clearly incapacitated." ${ }^{32}$

Soon thereafter, Douglas's close friend Charles Reich tried unsuccessfully to persuade the Justice to retire, ${ }^{330}$ and at the end of September Douglas returned to Washington for the beginning of October

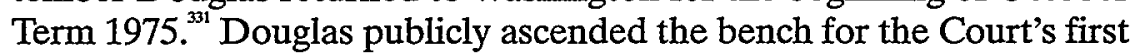
day of arguments on October 6, but during the very first hour, "his chin sank to his chest and he sat immobile for more than 10 minutes. The arguments were less than electric and as the minutes ticked by, it seemed increasingly likely that Justice Douglas was dozing.",32: Finally a Court messenger bearing a slip of paper got Douglas's attention, but at no point during the day's four hours of arguments did Douglas pose a question to any of the attorneys. In the afternoon he appeared more alert than he had in the morning, ${ }^{333}$ and two days later, even though Douglas was more than an hour late for the morning's arguments, "he also seemed quite alert and at ease. ${ }^{334}$

Outside the public eye, however, Douglas's colleagues knew they were confronting an exceptionally serious problem. To some at the Court, a clear pattern emerged in the very first week of the term: "Douglas had moments of lucidity and energy followed by near incoherence and sleep.,"335 At the end of the term's second week, on Friday, October 17, Douglas's eight colleagues resolved to continue their private accord that no decision by the Court should hinge on Douglas's vote and by a vote of seven to one extended it to preclude any opinion writing from being assigned to Douglas. ${ }^{336}$

Justice Byron R. White dissented, and on the following Monday he sent a long letter of protest to the seven other justices. Acknowledging that "there are one or more Justices who are so doubtful about the competence of Mr. Justice Douglas" to such an extent "that they

327 Douglas Plans to Keep Working, NY Times 14 (Sept 13, 1975). See also Woodward and Armstrong, The Brethren at 389-90 (cited in note 307) (asserting that Douglas's unresponsiveness lasted thirteen minutes); James Reston, Mr. Justice Douglas, NY Times 45 (Sept 17, 1975) (describing the silence as lasting nine and a half minutes).

328 See Smith v United States, 423 US 1303 (1975) (Douglas), vacated by 423 US 810 (1975).

329 Woodward and Armstrong, The Brethren at 390 (cited in note 307).

330 Id at 390-91.

331 See Lesley Oelsner, Douglas Present as Court Returns, NY Times 28 (Sept 30, 1975). 1975).

332 Joseph Lelyveld, Douglas Stirs Interest At Reopening of Court, NY Times 16 (Oct 7,

333 See id.

334 Lesley Oelsner, A Different Mr. Douglas Carries On, NYTimes IV 4 (Oct 12,1975).

335 Woodward and Armstrong, The Brethren at 392 (cited in note 307).

336 See Jeffries, Justice Lewis F. Powell, Jr. at 417 (cited in note 288); Hutchinson, The Man Who Once Was Whizzer White at 434 (cited in note 288). 
would not join any opinion purportedly authored by him," White nonetheless contended that "the action voted by the Court exceeds its powers and perverts the constitutional design.,"3in Arguing that the Constitution "nowhere provides that a Justice's colleagues may deprive him of his office by refusing to permit him to function as a Justice," White asserted that only impeachment by Congress could divest Douglas of his responsibilities. "If Congress were to provide by statute that Supreme Court Justices could be removed from office whenever an official commission, acting on medical advice, concluded that a Justice is no longer capable of carrying on his duties, surely there would be substantial questions about the constitutionality of such legislation." $" 338$

White admitted that "[i]t would be better for everyone, including Mr. Justice Douglas, if he would now retire," but he noted that Douglas "listens to oral arguments, appears in conference and casts his vote on argued cases. He thus not only asserts his own competence to sit but has not suggested that he is planning to retire." ${ }^{339}$ White insisted that "I am not convinced, as each of my seven colleagues seem to be, that there is such doubt about the condition of Mr. Justice Douglas that I should refuse to join any opinion that he might write," and the Constitution's guarantee of judicial independence included a justice's "freedom from removal by his colleagues."

Justice White conspicuously declared that "I am convinced that it would have been better had retirement been required at a specified age" by the Constitution and he volunteered that "a constitutional amendment to that effect should be proposed and adopted." ${ }^{3+1}$ But in the absence of any such provision, White believed that

[i]f the Court is convinced that Justice Douglas should not continue to function as a Justice, the Court should say so publicly and invite Congress to take appropriate action. If it is an impeachable offense for an incompetent Justice to purport to sit as a judge, is it not the task of Congress, rather than of this Court, to undertake proceedings to determine the issue of competence? If it is not an impeachable offense, may the Court nevertheless con-

337 Byron R. White to Warren E. Burger (Oct 20, 1975) 1, in Lewis F. Powell, Jr., Papers, Correspondence with Fellow Justices, Retirement of William O. Douglas, 1975-1978 (Law Library, Washington \& Lee University School of Law) ("Lewis F. Powell, Jr., Papers"). I thank archivist John Jacob for his kind assistance in sending me a copy of the documents contained in that file folder. See also Hutchinson, The Man Who Once Was Whizzer White at 463-65 (cited in note 288) (reprinting the White to Burger letter in full).

338 Byron $R$. White to Warren E. Burger at $i-2$ (cited in note 337 ).

339 Id at 2.

340 Id at 3.

341 Id. 
clude that a Justice is incompetent and forbid him to perform his duties? $?^{3+2}$

White clearly believed that the answer to his second question was no, but since his colleagues' decision was "plainly a matter of great importance," he challenged them to make public a "formal disclosure of the action" that they had taken."

No news release was forthcoming, but the news media's discussion of Douglas's condition and competence continued apace. ${ }^{3+4}$ The Justice was hospitalized again at the end of October, ${ }^{345}$ but two weeks later, on November 11, Douglas finally agreed to retire and the official announcement was made the very next day. ${ }^{346}$ Douglas's failure to retire eight months earlier had forced the Court into "a crisis mentality" for parts of two successive terms, ${ }^{347}$ and following his official retirement the mentally incapacitated Douglas repeatedly tried to participate in the Court's consideration of pending cases even after his angry colleagues bluntly ordered him to cease and desist. ${ }^{348}$

\section{A SECOND REFORM CAMPAIGN, 1974-1980}

The public scandal of a mentally decrepit, seventy-six-year-old Justice William O. Douglas attempting to cling to his Court seat throughout the spring and fall of 1975 happened to coincide with the early stages of another congressional attempt to authorize the involuntary removal of elderly, incapacitated justices. Following the collapse of the bar associations' drive for a constitutional amendment in 1955, a full decade passed before the ABA readdressed the subject. ${ }^{349}$

342 Id.

343 Id.

344 See Burden of Responsibility, NY Times 44 (Oct 22,1975) (an editorial stating that the question of Douglas's health "is a matter of consuming interest to the bar and the bench, and to the general public as well").

345 See Douglas Is Taken to Medical Center With "Slight Fever," NYTimes 41 (Oct 30, 1975).

346 See John P. MacKenzie, Douglas Retires From Court, Wash Post A1 (Nov 13, 1975); Lesley Oelsner, Douglas Quits Supreme Court; Ford Hails 36 1/2-Year Service, NY Times 1 (Nov 13, 1975).

347 Hutchinson, The Man Who Once Was Whizzer White at 436 (cited in note 288).

348 See, for example, William O. Douglas to Warren E. Burger (Dec 20, 1975), in Lewis F. Powell, Jr., Papers (cited in note 337); Warren E. Burger, et al, to William O. Douglas (Dec 22, 1975), in Lewis F. Powell, Jr., Papers; William O. Douglas, Memorandum to the Conference: In re Capital Cases (Mar 30, 1976), in Lewis F. Powell, Jr., Papers. See also Jeffries, Justice Lewis F. Powell, Jr. at $418 \mathrm{n}$ * (cited in note 288) (noting that Douglas returned to the Court after retiring and "behaved as if he were still sitting"); Simon, Independent Journey at 452-54 (cited in note 321) (noting that Douglas insisted that he was "the tenth member" of the Court after retiring); Woodward and Armstrong, The Brethren at 396-99, 433 (cited in note 307) (describing how Douglas, after retirement, arrived at his office and summoned his clerks as if he were still a justice).

349 But see Report of the Standing Committee on Jurisprudence and Law Reform, 88 Annual Rep ABA 199, 200,202 (1963) (recommending the rescission of the ABA's 1950 and 1954 resolu- 
In 1965 two ABA committees jointly recommended an inquiry into "compulsory retirement of judges with permanent physical or mental disabilities." $"$ The ABA committee members had been encouraged in their efforts by both United States Attorney General Nicholas Katzenbach and Deputy Attorney General Ramsey Clark, ${ }^{351}$ but the ABA activists envisioned a constitutional amendment that would apply to all federal judges but not to justices of the Supreme Court. ${ }^{352}$ The recommendation was approved, ${ }^{353}$ and the ABA began working closely with Maryland Democratic Senator Joseph D. Tydings, who was actively interested in improving the federal judiciary.

In 1968 and again in 1969 Senator Tydings introduced a bill authorizing the involuntary removal of lower federal court judges by vote of the Judicial Conference of the United States, ${ }^{355}$ but Tydings's electoral defeat in 1970 brought his effort to an abrupt end. ${ }^{356}$ Between

tions endorsing a constitutional amendment mandating federal judicial retirement at age seventy-five because of the lack of "adequate documentation regarding [the] inability, ineptness or undesirability of a federal judiciary beyond 75 years of age"); Proceedings of the 1963 Midyear Meeting of the House of Delegates, 88 Annual Rep ABA 90, 100-01 (1963) (referring that recommendation to four separate committees for reconsideration). No further action on it occurred or was recommended. See 89 Annual Rep ABA (1964).

350 Report of the Standing Committee on Judicial Selection, Tenure and Compensation, 90 Annual Rep ABA 446, 446-47,449-51 (1965); Report of the Section of Judicial Administration, 90 Annual Rep ABA 587,587-95 (1965).

351 See Report of the Standing Committee, 90 Annual Rep ABA at 451 (cited in note 350). The internal leader of the ABA efforts was N.Y. Supreme Court Justice Miles F. McDonald.

352 See Report of the Section of Judicial Administration, 90 Annual Rep ABA at 593-94 (cited in note 350). See also J. Earl Major, Why Not Mandatory Retirement for Federal Judges?, 52 ABA J 29, 29 (1966) (proposing that "retirement be made mandatory at age seventy (sixtyfive would be better)").

353 See Proceedings of the House of Delegates at the 1965 Annual Meeting, 90 Annual Rep ABA 310,337-39 (1965).

354 See Report of the Standing Committee on Judicial Selection, Tenure and Compensation, 92 Annual Rep ABA 442, 447 (1967); Report of the Standing Committee on Judicial Selection, Tenure and Compensation, 91 Annual Rep ABA 496, 496-97 (1966).

355 See Judicial Reform Act of 1968, S 3055, 90th Cong, 2d Sess, in 114 Cong Rec S 4558 (Feb 28, 1968); Judicial Reform Act, S 1506, 91st Cong, 1st Sess, in 115 Cong Rec S 6217, 6220 (Mar 12, 1969). See also Larry C. Berkson and Irene A. Tesitor, Holding Federal Judges Accountable, 61 Judicature 442, 454 (1978) (specifically discussing the Tydings proposal); Stewart A. Block, Comment, The Limitations of Article III on the Proposed Judicial Removal Machinery: $S$. 1506, 118 U Pa L Rev 1064 (1970). After extended debate, the ABA endorsed Tydings's bill. See Report of the Standing Committee on Judicial Selection, Tenure and Compensation, 94 Annual Rep ABA 468, 469, 472-73 (1969); Proceedings of the 1969 Annual Meeting of the House of Delegates, 94 Annual Rep ABA 378,396-97 (1969); Report of the Standing Committee on Judicial Selection, Tenure and Compensation, 95 Annual Rep ABA 212,212-14 (1970); Report of the Section of Judicial Administration, 95 Annual Rep ABA 396, 396 (1970); Proceedings of the 1970 Midyear Meeting of the House of Delegates, 95 Annual Rep ABA 123, 147-48 (1970).

356 See Report of the Standing Committee on Judicial Selection, Tenure and Compensation, 96 Annual Rep ABA 213,216 (1971) (noting that Tydings's defeat lessened the chance of passage of judicial reform legislation); Report of the Standing Committee on Judicial Selection, Tenure and Compensation, 96 Annual Rep ABA 636, 638 (1971) (noting that Tydings's defeat "gave a temporary setback" to enactment of judicial reform legislation); Report of the Standing Committee on 
1968 and 1970, eleven members of the House of Representatives, including George Bush of Texas, introduced different resolutions proposing constitutional amendments that would mandate compulsory retirement at age seventy, seventy-two, or seventy-five, but none of the measures received any public attention or congressional consideration. $^{357}$ A former Chief Justice of Texas, Robert W. Calvert, noting that some forty of the fifty states imposed a mandatory judicial retirement age, observed that "there is no sound basis for concluding that state judges age, become tired and grow out-of-touch, but that federal judges do not."358 Calvert called for adoption of a constitutional

Judicial Selection, Tenure and Compensation, 97 Annual Rep ABA 239, 241 (1972) (reporting that the Tydings bill "died in committee" after his electoral defeat).

357 See H J Res 1126, 90th Cong, 2d Sess, in 114 Cong Rec H 4040 (Feb 26, 1968) (introduced by Representative Taylor of North Carolina and proposing age seventy); H J Res 1386 , 90th Cong, 2d Sess, in 114 Cong Rec H 20000, 20011 (July 3, 1968) (introduced by Representative Thompson of Georgia and proposing age seventy-five); H J Res 1407, 90th Cong, 2d Sess, in 114 Cong Rec H 20800 (July 11, 1968) (introduced by Representative Rogers of Florida and proposing age seventy); H J Res 1439, 90th Cong, 2d Sess, in 114 Cong Rec H 25110 (Aug 2, 1968) (introduced by Representative Winn of Kansas and proposing age seventy); H J Res 1448, 90th Cong, 2d Sess, in 114 Cong Rec H 26215, 26265 (Sept 10, 1968) (introduced by Representative Abbitt of Virginia and proposing age seventy); H J Res 1456, 90th Cong, 2d Sess, in 114 Cong $\operatorname{Rec} \mathrm{H} 26648$ (Sept 12, 1968) (introduced by Representative Randall of Missouri and proposing age seventy-two); H J Res 125, 91st Cong, 1st Sess, in 115 Cong Rec H 89 (Jan 3, 1969) (introduced by Representative Bevill of Alabama and proposing age seventy); Reconfirmation Every 10 Years and Mandatory Retirement at Age 70 Urged for Supreme Court Justices, 91st Cong, 1st Sess, in 115 Cong Rec H 349 (Jan 8, 1969) (Representative Abbitt of Virginia announcing that he will reintroduce his 1968 proposal); H J Res 536, 91st Cong, 1st Sess, in 115 Cong Rec H 6111, 6115 (Mar 12,1969) (introduced by Representative Bush of Texas and proposing age seventy); $H$ J Res 817, 91st Cong, 1st Sess, in 115 Cong Rec H 19660 (July 15,1969) (introduced by Representative Wydler of New York and proposing age 70); H J Res 1047, 91st Cong, 2d Sess, in 116 Cong Rec H 332 (Jan 20,1970) (introduced by Representative Bennett of Florida and proposing age seventy); H J Res 1081, 91st Cong, 2d Sess, in 116 Cong Rec H 3198-99 (Feb 10, 1970) (introduced by Representative Sikes of Florida and proposing age seventy).

Representative Sikes reintroduced his proposal as $\mathrm{H} J$ Res 176 in the subsequent $92 \mathrm{~d}$ Congress, H J Res 176, 92d Cong, 1st Sess, in 117 Cong Rec H 216 (Jan 22, 1971); Representative Bennett reintroduced his in the 93d Congress, $\mathrm{H} J$ Res 61,93d Cong, 1st Sess, in 119 Cong Rec $\mathrm{H}$ 71 (Jan 3, 1973); and Representative Bevill similarly reintroduced his, H J Res 129,93d Cong, 1st Sess, in 119 Cong Rec H 411 ( $\operatorname{Tan} 6,1973$ ). Also in 1973 Representative Seiberling of Ohio introduced $\mathrm{H} J$ Res 375 , calling for mandatory judicial retirement at age seventy-one and mandatory congressional retirement. See H J Res 375, 93d Cong, 1st Sess, in 119 Cong Rec H 5095 (Feb 22, 1973). See also H J Res 461, 93d Cong, 1st Sess, in 119 Cong Rec H 9481 (Mar 26, 1973) (introduced by Representative Broomfield of Michigan and proposing age sixty-six); H J Res 511,93d Cong, 1st Sess, in 119 Cong Rec H 12588 (Apr 16,1973) (introduced by Representative Sikes and proposing age seventy); $\mathrm{H} J$ Res 511,93d Cong, 1st Sess, in 119 Cong Rec H 13209 (Apr 18, 1973) (Representative Sikes reintroducing his proposal); H J Res 583, 93d Cong, 1st Sess, in 119 Cong Rec H 17393 (May 30,1973) (introduced by Representative Archer of Texas and proposing age seventy).

358 Calvert, 54 Judicature at 425 (cited in note 3). See also Thomas E. Baker, The Good Judge: Report of the Twentieth Century Fund Task Force on Federal Judicial Responsibility 83 (Priority 1989) (reporting that thirty-seven states then had mandatory judicial retirement provisions); Bernard S. Meyer, Judicial Retirement Laws of the Fifty States and the District of Columbia (Fordham 1999) (attempting to comprehensively collect all relevant statutory provisions). Despite some inconsistencies and contradictions, Meyer's data appear to indicate that fourteen 
amendment requiring retirement at age seventy and optimistically predicted, "just ask Congress to submit it and watch its speedy ratification by the states." ${ }^{\text {,3s }} \mathrm{ABA}$ leaders continued to espouse a new removal mechanism, but worried that "impetus appears to have been lost" in the absence of a congressional champion.

That gap was filled in October 1974 when Georgia Democratic Senator Sam Nunn introduced a bill that expanded upon Tydings's 1969 measure to include Supreme Court justices as well. ${ }^{31}$ Nunn reintroduced his bill as S 1110 in the new Congress in March 1975, ${ }^{3 \times 2}$ and the very next day Chief Justice Warren E. Burger and the United States Judicial Conference announced their support for a somewhat narrower approach that would police "mental disability" and other shortcomings among lower federal court judges but would not cover justices of the Supreme Court. ${ }^{363}$ Nunn's bill specifically proposed that for any federal judge or justice who was eligible for retirementranging from age sixty-five with fifteen or more years of federal

states have no mandatory retirement provisions (California, Delaware, Idaho, Kentucky, Maine, Mississippi, Montana, Nebraska, Nevada, New Mexico, Oklahoma, Rhode Island, Tennessee, and West Virginia). See Meyer, Judicial Retirement Laws at 90, 149 (noting inconsistencies in Idaho and Montana). See also Ruth Marcus, Unlikely Litigants: State Judges Battle Mandatory Retirement, Wash Post A1 (Mar 17,1991) (reporting that thirty-six of the fifty states do set retirement ages for judges); Ruth Marcus, State Age Limits for Judges Upheld; Supreme Court Ruling Preserves Lacal Retirement Regulations, Wash Post A10 (June 21, 1991) (same). Although various exceptions abound, it appears from Meyer's data as if twenty-three states basically impose mandatory retirement at age seventy, four at age seventy-two (Colorado, Iowa, North Carolina, and South Carolina), one at age seventy-three (North Dakota), and eight at age seventy-five (Georgia, Illinois, Indiana, Iowa, Oregon, Texas, Utah, and Washington). See Meyer, Judicial Retirement Laws at 6, 94,236,264. Meyer advocates authorizing imposition of involuntary retirement only when mental or physical disability warrants doing so. Id at 31 . See also id at 33 (A "[m]ental disability should be defined as one that so obfuscates or slows down the judge's thought process as to materially affect the discharge of judicial duties.").

359 Calvert, 54 Judicature at 427 (cited in note 3).

360 Report of the Standing Committee on Judicial Selection, Tenure and Compensation, 97 Annual Rep ABA 676, 677 (1972); Proceedings of the 1972 Annual Meeting of the House of Delegates, 97 Annual Rep ABA 528,549-50 (1972); Report of the Standing Committee on Judicial Selection, Tenure and Compensation, 98 Annual Rep ABA 578, 581-83 (1973); Proceedings of the 1973 Annual Meeting of the House of Delegates, 98 Annual Rep ABA 432, 455-56 (1973).

361 See Judicial Tenure Act, S 4153, 93d Cong, 2d Sess, in 120 Cong Rec S 36064-68 (Oct 17, 1974). Nunn later said that his bill covered justices as well as judges "because, in my view, the Constitution makes no distinction between the tenure of the Supreme Court Justices and lesser federal judges." Sam Nunn, The Judicial Tenure Act, 13 Trial 26, 29 (Nov 1977).

362 See S 1110,94th Cong, 1st Sess, in 121 Cong Rec S 5675 (Mar 7, 1975). See also HR 1273, 94th Cong, 1st Sess, in 121 Cong Rec H 628 (Jan 17, 1975) (parallel bill introduced by Representative Eilberg); Procedures to Remove Federal Judges, HR 10439, 94th Cong, 1st Sess, in 121 Cong Rec H 34479 (Oct 30,1975) (Representative Findley of Illinois introducing a proposal for a simpler intra-judiciary removal mechanism).

363 See Warren Weaver, Jr., Burger Endorses Purge of Judges, NY Times 30 (Mar 8, 1975). See also Judicial Tenure Act, Hearing before the Subcommittee on Improvements in Judicial Machinery of the Committee on the Judiciary, United States Senate, on S 1423, 95th Cong, 1st Sess 49 (Sept 14,1977) (reprinting the March 1975 Judicial Conference statement). 
judicial service to age seventy with at least ten years of service-if a majority of the Judicial Conference found "that such Justice or judge is unable to discharge efficiently one or more of the critical duties of his office by reason of a permanent mental or physical disability, the Conference shall certify the disability of such Justice or judge and issue an order removing such Justice or judge from active service .... Such Justice or judge shall then be involuntarily retired from regular active service."

Nunn's bill represented a radical innovation, but it was based on the widely rejected premise that impeachment was not the sole constitutionally permissible means of removing an Article III judge. ${ }^{365}$ The well known scholar Raoul Berger enthusiastically supported Nunn's stance, ${ }^{366}$ as did some other writers and organizations, ${ }^{367}$ but the predominant view was that only a new constitutional amendment, and not simply an act of Congress, could provide for removal other than by congressional impeachment. ${ }^{369}$ Nonetheless the American Bar As-

364 S 1110 at 121 Cong Rec S 5675 (cited in note 362). See also Judicial Tenure Act, Hearings Before the Subcommittee on Improvements in Judicial Machinery of the Committee on the Judiciary, United States Senate, on S 1110, 94th Cong, 2nd Sess 3-20 (Feb 18-Mar 11, 1976) (reprinting S 1110). Congress in the Act of September 2, 1957, 71 Stat 586, had "authorized the circuit judicial councils to certify a judge as disabled by a majority vote of the members of the judge's judicial council," thus allowing a new judge to be appointed but not removing the "disabled" judge from active service. Van Tassel, 142 U Pa L Rev at 403 (cited in note 59). In addition, Congress, in the Act of August 6,1958,72 Stat 497, required the chief judges of both circuit and district courts to relinquish that administrative post, although of course not their active judgeship, at age seventy. See Peter Graham Fish, The Politics of Federal Judicial Administration 257 (Princeton 1973).

365 See Sam Nunn, Judicial Tenure, 54 Chi Kent L Rev 29, 39-40 (1977) (arguing that "the framers must have contemplated a disciplinary mechanism for less than extreme cases of abuse").

366 See Raoul Berger, "Chilling Judicial Independence": A Scarecrow, 64 Cornell L Rev 822, 837-49 (1979); Raoul Berger, Impeachment: The Constitutional Problems 122-80 (Harvard 1973); Raoul Berger, Impeachment of Judges and "Good Behaviour" Tenure, 79 Yale L J 1475, 1521-25 (1970).

367 See Wright H. Andrews, Jr., Judicial Removal of Federal Judges, 11 Ga St B J 157, 158-59 (1975); Thomas M. Boyd, Federal Judges: To Whom Must They Answer?, 61 ABA J 324, 326 (1975); John S. Clark, The Federal Judicial Tenure Act, 58 Judicature 464, 464 (1975) (the American Judicature Society endorsing S 1110). See also Harry F. Byrd, Jr., Has Life Tenure Outlived Its Time?, 59 Judicature 266 (1976) (advocating a constitutional amendment requiring Senate reconfirmation of newly named federal judges every eight years); Robert Kramer and Jerome A. Barron, The Constitutionality of Removal and Mandatory Retirement Procedures for the Federal Judiciary: The Meaning of "During Good Behaviour," 35 Geo Wash L Rev 455, 472 (1967) (asserting that a federal statute providing for mandatory judicial retirement "should not be considered unconstitutional"); Burke Shartel, Federal Judges-Appointment, Supervision, and Removal-Some Possibilities under the Constitution, 28 Mich L Rev 870, 909 (1930).

368 See Irving R. Kaufman, The Essence of Judicial Independence, 80 Colum L Rev 671 (1980); Irving R. Kaufman, Chilling Judicial Independence, 88 Yale L J 681, 690-703 (1979); Note, Judicial Disability and the Good Behavior Clause, 85 Yale L J 706, 707,712-18 (1976); J. Clifford Wallace, Must We Have the Nunn Bill? The Alternative of Judicial Councils of the Circuits, 51 Ind L J 297,307-08 (1976); Frank J. Battisti, An Independent Judiciary or an Evanescent Dream?, 25 Case W Res L Rev 711, 732 \& n 119 (1975). See also William S. Carpenter, Judicial Tenure in the 
sociation endorsed it, subject only to a caveat that it should not apply to Supreme Court Justices, just to lower federal judges, ${ }^{3,9}$ and in early 1976 a Senate Judiciary subcommittee held five days of hearings on Nunn's bill. ${ }^{370}$

Nunn himself told the subcommittee that he had been interested in the issue even before his 1972 election to the Senate. Insisting that "a constitutional amendment is not necessary," Nunn also conceded that such an amendment "would be very, very difficult to pass." representative John A. Sutro noted that the ABA had recommended that Nunn remove coverage of Supreme Court Justices from his bill since the Judicial Conference had no administrative jurisdiction over the Supreme Court, ${ }^{3 / 2}$ and another ABA representative, J. Michael McWilliams, stressed that "the impeachment process is sufficient for the Supreme Court." ${ }^{373}$ Similar stances were articulated by both Circuit Judge Robert A. Ainsworth, Jr., speaking in his capacity as chairman of the Committee on Court Administration of the Judicial Conference of the United States, ${ }^{374}$ and former ABA president Robert W. Meserve, speaking on behalf of the American Judicature Society.

The Judiciary Committee took no action on Nunn's bill before the end of the Ninety-fourth Congress, and Nunn reintroduced a largely similar measure as S 1423 in the Ninety-fifth Congress in April 1977. ${ }^{3 / 6}$ In September 1977, the same Senate Judiciary subcommittee held one day of hearings on the bill, and when asked about its application to Supreme Court Justices, Nunn readily conceded that "I know that this will be one of the most controversial points." He stressed,

\footnotetext{
United States 101, 127, 130 (Yale 1918) (introducing a detailed review of the framers' views concerning judicial impeachment and noting how in several states in the early nineteenth century, the procedure of "address," rather than impeachment, was accepted as the most appropriate means for dealing with judicial decrepitude or incapacity); $\mathrm{H}$ J Res 912, 94th Cong, 2d Sess, in 122 Cong Rec H 9605 (Apr 6, 1976), and 122 Cong Rec H 12253 (May 3, 1976) (Representative Frey of Florida proposing a constitutional amendment allowing for the removal of any Supreme Court Justice unable to discharge the duties of office "by reason of a permanent mental or physical disability").

${ }^{369}$ See Report of the Standing Committee on Judicial Selection, Tenure and Compensation, 100 Annual Rep ABA 306 (1975); Proceedings of the 1975 Midyear Meeting of the House of Delegates, 100 Annual Rep ABA 227, 262-63 (1975); Report of the Standing Committee on Judicial Selection, Tenure and Compensation, 100 Annual Rep ABA 788, 789 (1975) (stating that "[o]ur Committee is of the unanimous view that the Supreme Court should be excluded"); Proceedings of the 1975 Annual Meeting of the House of Delegates, 100 Annual Rep ABA 642, 675

(1975) (approving the Committee's recommendation without debate).

370 See Judicial Tenure Act, Hearings on S 1110 (cited in note 364).

371 Id at 29.

372 See id at $46-47$.

$373 \mathrm{Id}$ at 52 .

374 See id at 73.

375 See id at 154 .

376 See Judicial Tenure Act, S 1423, 95th Cong, 1st Sess, in 123 Cong Rec S 12964, 12965 (Apr 29, 1977). See also Hearing on S 1423 at 3-20 (cited in note 363).
} 
however, without mentioning Justice Douglas by name, that "[i]mpeachment has been shown in recent experience to be a totally improbable instrument to be used in the case of a Supreme Court judge who is senile or disabled." 37 Former Senator Tydings endorsed Nunn's proposal except for its contemplated coverage of the Supreme Court. "My sole caveat is that the jurisdiction to be constitutional should be limited to those judges created by statute and not Justices of the Supreme Court created by Article III of the Constitution. In my judgment, such inclusion would clearly invalidate your proposed legislation both legally and politically." tro restated his 1976 testimony, and attempted to rebut Nunn's comment about the significance of Justice Douglas's incapacity. "I believe that a Justice of the Supreme Court of the United States who became senile or otherwise physically or mentally incapacitated, in the exercise of his good judgment and aided by his family and by his brother Justices of the Supreme Court, would see fit to step down. I can cite as an instance Justice Douglas not so long ago.",779

By the time that the full Senate Judiciary Committee issued a favorable report on Nunn's bill ten months later in July 1978, the Committee had amended the measure so that the proposed disciplinary voice of the Judicial Conference, the "Court on Judicial Conduct and Disability," could with regard to Supreme Court justices merely make a recommendation of impeachment to the House of Representatives if a justice engaged in conduct inconsistent with the constitutional requirement of "good behavior."

377 Hearing on S 1423 at 59-60 (cited in note 363).

378 Id at 63. See also Carpenter, Judicial Tenure in the United States at 140-41 (cited in note 368) (noting the advocacy of a similar distinction by Representative Hull of Tennessee in the 63d Congress, 1st Session, in 1913 in introducing H J Res 114); The Committee on Federal Legislation of the Association of the Bar of the City of New York, The Removal of Federal Judges Other Than By Impeachment, 32 Rec of the Assn of the Bar of the City of NY 239 (1977) (a partial text expressing strong opposition to the Supreme Court provisions of the Nunn bill), reprinted in full form in Judicial Tenure and Discipline-1979-1980, Hearings before the Subcommittee on Courts, Civil Liberties, and the Administration of Justice of the House Committee on the Judiciary, 96th Cong, 1st \& 2d Sess 780, 782, 787-88 (July 12-13, 1979, and Mar 27, 31, 1980).

379 Hearing on $S 1423$ at 105 (cited in note 363 ). Sutro added that "I think impeachment does provide a remedy" for a problem with an incapacitated Justice. Id at 106. See also Bar Approves a Set of Standards to Punish and Oust Unfit Judges, NY Times A20 (Feb 15, 1978); Proceedings of the 1978 Midyear Meeting of the House of Delegates, 103 Annual Rep ABA 203, 23435 (1978); Report of the Standing Committee on Judicial Selection, Tenure and Compensation, 103 Annual Rep ABA 289, 289 (1978); Proceedings of the 1977 Annual Meeting of the House of Delegates, 102 Annual Rep ABA 501, 538 (1977); Report of the Standing Committee on Judicial Selection, Tenure and Compensation, 102 Annual Rep ABA 649, 650-51 (1977).

380 See Judicial Tenure Act, S Rep No 95-1035, 95th Cong, 2d Sess 2-3, 37-41, 57-59 (July 24,1978 ). The revised bill included no explicit invocation concerning a justice's "mental disability," but said only that conduct inconsistent with "good behavior includes, but is not limited to, willful misconduct in office, willful and persistent failure to perform duties of the office, habitual intemperance, or other conduct prejudicial to the administration of justice." Id at 58. See also 
opposition to any Supreme Court coverage, ${ }^{381}$ but even with that provision deleted, some Senators continued to oppose any and all policing mechanisms other than impeachment, even for just lower federal judges.

From that point forward in S 1423's congressional consideration, the question of whether any one or another form of the bill might provide for the involuntary removal of mentally decrepit or incapacitated Supreme Court Justices was off the table. The full Senate passed the trimmed-down committee version of the measure on September 7, 1978 , by a margin of forty-three to thirty-two, following a debate in which Senator Nunn himself endorsed the Committee's modification as an improvement upon his previous bill.

I believe the committee has come to an approach here which is not only judicious but also has a lot of commonsense. I like it better than the approach I originally drafted. I think the Congress would deal with a Supreme Court judge in those cases [by means of impeachment], but I do not think [a time-consuming congressional impeachment] will ever happen with a district judge.

Even Senator Nunn acknowledged that the Senate-passed bill had no prospects for favorable consideration in the House before the end of the Ninety-fifth Congress, ${ }^{385}$ and in the new Ninety-sixth Congress in early 1979 , Senator Nunn reintroduced the final, Senatepassed version of S 1423 as S 295 . $^{336}$ Two days of Senate subcommittee

Reports of Committees, 95th Cong, 2d Sess, in 124 Cong Rec S 22427 (July 24, 1978) (noting the filing of the Judiciary Committee report); Report of the Standing Committee on Judicial Selection, Tenure and Compensation, 103 Annual Rep ABA 718 (1978) (implicitly suggesting that the alteration in the Nunn bill was made at the full committee level); Additional Views of Senator Birch Bayh on S 1423, as Amended, the Judicial Tenure Bill, 95th Cong, 2d Sess, in 124 Cong Rec S 28302, 28303 (Sept 7,1978) (explaining that the bill "was amended in subcommittee" to alter the provision pertaining to Supreme Court justices).

381 See S Rep No 95-1035 at 41 (cited in note 380).

382 See id at 63 (Senator Birch Bayh), 73-74 (Senator Charles McC. Mathias). See also Charles McC. Mathias, Jr., Judicial Independence: $A$ Principle Worth Preserving, 13 Md Bar J 28, 28 (Summer 1980); J. Clifford Wallace, The Nunn Bill: An Unneeded Compromise of Judicial Independence, 61 Judicature 476,478-79 (1978). But see J. Edward Lumbard, The Nunn Bill:A Way to Ensure Judicial Accountability, 61 Judicature 477, 483 (1978).

383 See Judicial Tenure Act, 95th Cong, 2d Sess, in 124 Cong Rec S 28254, 28284, 28319, 28321 (Sept 7, 1978).

384 Id at $\mathrm{S} 28300$.

385 See id at S 28315 (Senator Nunn admitting that "it is obvious it probably is not going to get very far in the House"); Judicial Tenure Act, 95th Cong, 2d Sess, in 124 Cong Rec H 37255 (Oct 13,1978) (Representative Pease of Ohio advocating legislation similar to the Senate-passed bill). See also Alan Berlow, Senate Approves Method of Removing Judges Without Impeachment, Cong Q Wkly Rep 2493 (Sept 16, 1978) (noting that no House hearings on the bill were planned).

386 See S 295, 96th Cong, 1st Sess, in 125 Cong Rec S 1404 (Jan 31, 1979) (introduced by Senators Nunn and DeConcini). See also Disciplining Judges: New Efforts in an Old Controversy, Cong Q Wkly Rep 640 (Apr 7,1979). 
hearings were conducted in May and June $1979,{ }^{3 \circ}$ and two days of House subcommittee hearings in July, ${ }^{38 s}$ before the Senate Judiciary Committee in early October approved and sent to the full Senate a new "clean" bill, S 1873, which included no coverage whatsoever of Supreme Court justices and otherwise significantly revised the lower court disciplinary system previously envisioned by Senator Nunn. ${ }^{399}$

That new bill was brought to the Senate floor on October 30, and its supporters emphasized that $\mathrm{S} 1873$ did not contain any "provisions covering the conduct of U.S. Supreme Court Justices" or indeed any mechanism for the actual removal of even lower court judges other than by full congressional impeachment. ${ }^{390}$ Senator Nunn went through the motions of offering his previously truncated $S 295$ as a substitute for the Committee's bill, ${ }^{391}$ and Senator Dennis DeConcini explained on behalf of the Committee that "it was the strong consensus on both sides of the aisle that the compromise legislation ... was what was most practical and most realistic" for consideration by the full Senate. ${ }^{392}$ Nunn's more assertive bill was rejected by a vote of sixty to thirty, ${ }^{393}$ and then, with Nunn backing the far more modest Committee bill, $^{324}$ it in turn was approved on a vote of fifty-six to thirty-three. ${ }^{395}$

In the House, renewed subcommittee hearings took place in March $1980,{ }^{366}$ and between May and early September, the House Judiciary Committee produced and approved a bill much more closely

387 See Judicial Discipline and Tenure, Hearing before the Subcommittee on Judicial Machinery and the Constitution of the Senate Committee on the Judiciary, 96th Cong, 1st Sess (May 8 and June 25,1979).

388 See Judicial Tenure and Discipline (cited in note 378). See also H J Res 334, 96th Cong, 1st Sess, in 125 Cong Rec H 11484 (May 16, 1979) (introduced by Representative Clinger, which proposed term limits for members of Congress as well as mandatory legislative and judicial retirement at age seventy).

389 See Senate Judiciary Committee Reports a Bill Providing For Disciplining Federal Judges, Cong Q Wkly Rep 2224 (Oct 6, 1979); The Judicial Conduct and Disability Act of 1979, S Rep No 96-362, 96th Cong, 1st Sess 1 (Oct 10,1979) (reporting favorably on S 1873); Stephen B. Burbank, Procedural Rulemaking under the Judicial Councils Reform and Judicial Conduct and Disability Act of 1980, 131 U Pa L Rev 283, 296-300 (1982); John H. Culver and Randal L. Cruikshanks, Judicial Discipline at the Federal Level: A New Response to an Old Problem, in Philip L. DuBois, ed, The Analysis of Judicial Reform 107, 112 (Lexington 1982). See also Judicial Tenure and Discipline at 311-25 (cited in note 378) (reprinting S 1873 in full).

390 Consideration of the Judicial Conduct and Disability Act of 1979, S 1873,96th Cong, 1st Sess, in 125 Cong Rec S 30043,30051 (Oct 30,1979). See also Report No. 1 of the Standing Committee on Judicial Selection, Tenure and Compensation, 105 Annual Rep ABA 755, 758 (1980) (reporting that "in the belief that half a loaf is better than none, and in order to promptly move the legislation, the constitutional issue has been avoided").

391 See 96th Cong, 1st Sess, in 125 Cong Rec S 30080 (Oct 30, 1979).

392 Id at S 30086.

393 See id at $S 30094$.

394 See id at $S 30095$.

395 Id at S 30100. See also Senate Approves Procedures To Discipline Federal Judges Short of Impeachment Action, Cong Q Wkly Rep 2492 (Nov 3, 1979).

396 See Judicial Tenure and Discipline at 125 (cited in note 378 ). 
in keeping with the Judicial Conference's strongly expressed preference for a circuit-by-circuit approach to federal judicial discipline than the stronger, more centralized plans that all of the Senate bills had envisioned. ${ }^{37}$ The new bill, HR 7974, was brought to the House floor and passed under a suspension of the rules on September $15,1980 .^{358}$ Fifteen days later the Senate approved it after adding a handful of modestly significant amendments, ${ }^{399}$ and the very next day the House concurred in the Senate's alterations and gave the bill its final congressional approval. ${ }^{40}$ President Jimmy Carter signed the measure into law on October 15, 1980, as the Judicial Councils Reform and Judicial Conduct and Disability Act of $1980^{401}$

\section{The Supreme COURT, 1981-1990}

From the perspective of the Supreme Court's extensive history with mentally decrepit justices, Senator Nunn's well intentioned but constitutionally questionable initiative in the end brought forth no reform or protection whatsoever. The question of Supreme Court coverage was always little more than a subsidiary issue in a more basic debate over what if any disciplinary methods other than impeachment were constitutionally permissible, and the particular problem of mental incapacity was never more than just one of a large handful of potential judicial shortcomings against which interested legislators hoped to protect.

397 See Nadine Cahodas, House Judiciary OK's Bill To Discipline Federal Judges Short of Impeachment Move, Cong Q Wkly Rep 2641 (Sept 6, 1980); Judicial Councils Reform and Judicial Conduct and Disability Act of 1980, HR Rep No 96-1313, 96th Cong, 2d Sess 6-7 (Sept 10, 1980); Burbank, 131 U Pa L Rev at 297 n 52 (cited in note 389) (noting that the Judicial Conference had expressed its explicit opposition to $\mathrm{S} 1873$ even just prior to that bill's October 30,1979 passage by the Senate and observing that "it was the House ... that bore major responsibility for fashioning the ultimate compromise legislation enacted in 1980"); Eric Neisser, The Origins of the New Judicial Discipline Act, 65 Judicature 146 (1981) (reporting that "[f]ollowing intensive negotiations, a compromise bill, H.R. 7974, developed in September 1980"); Robert W. Kastenmeier and Michael J. Remington, Judicial Discipline: A Legislative Perspective, $76 \mathrm{Ky} \mathrm{L} \mathrm{J} \mathrm{763,} 770$ (1987-88) (calling the 1980 Act "a compromise-consensus piece of legislation"); William G. Ross, The Hazards of Proposals to Limit the Tenure of Federal Judges and to Permit Judicial Removal Without Impeachment, 35 Vill L Rev 1063, 1119-22 (1990). See also Judicial Conduct and Disability Act of 1979,96th Cong, 1st Sess, in 125 Cong Rec S 30077,30079 (Oct 30,1979) (considering S 1873 and reprinting a Judicial Conference resolution adopted on March 9,1979).

398 See Judicial Councils Reform and Judicial Conduct and Disability Act of 1980, HR 7974, 96th Cong, 2d Sess, in 126 Cong Rec H 25367, 25372-74 (Sept 15, 1980). See also House Approves Legislation to Discipline Federal Judges, Cong Q Wkly Rep 2757 (Sept 20,1980).

399 See Judicial Councils Reform and Judicial Conduct and Disability Act of 1980, S 1873, 96th Cong, 2d Sess, in 126 Cong Rec S 28086, 28092-93, 28098 (Sept 30, 1980).

400 See Establishing Procedure for Processing Complaints against Federal Judges, 96th Cong, 2d Sess, in 126 Cong Rec H 28614, 28617 (Oct 1, 1980). See also Nadine Cahodas, Congress Clears Legislation to Discipline Federal Judges, But Short of Impeachment, Cong Q Wkly Rep 2898 (Oct 4, 1980).

401 Originally codified at 28 USC $\$ \S 331,332,372$ (c) (1982). 
Just eight months after the final enactment of the altogether modest Judicial Conduct and Disability Act of 1980, Justice Potter Stewart, who had been named to the Supreme Court in 1958 at age forty-three, announced his retirement from the bench at the unusually young age of sixty-six. ${ }^{422}$ Meeting with reporters the very next day, Justice Stewart announced his belief that "it's better to go too soon than to stay too long." ${ }^{403}$ Stewart explained that seventeen months earlier, in February 1980, soon after his sixty-fifth birthday had made him eligible to retire at full pay, he had received a letter from a Minnesota high school student, written as part of a class assignment, asking why he was remaining on the Court despite his eligibility to retire. ${ }^{44}$ Stewart said the letter "sort of started me thinking,",35 but "I didn't want to do it in an election year and I didn't want to do it in the middle of a term." ${ }^{\text {4066 }}$ Thus he had waited until 1981. Asked whether he would support a constitutional amendment setting a mandatory retirement age for federal judges, Stewart allowed that "perhaps life tenure isn't ideal" but said that "it's hard to think of any ideal system." Just like Chief Justice Warren in $1966,{ }^{408}$ Stewart added that "I would not be against consideration of such an amendment-if it applied across the board to the other branches, too., ${ }^{409}$

Six months after Stewart's problem-free retirement, a largely unprecedented question involving apparently only the appearance of diminished capacity arose when news reports revealed that Associate Justice William $\mathrm{H}$. Rehnquist had been hospitalized for "drug withdrawal symptoms" which had included what a doctor termed "disturbances in mental clarity." hours on December 27, 1981, Rehnquist had "had some awarenesses that were not real" while being weaned from a serious overdependence on Placidyl, a powerful hypnotic or "sleeping pill" that had been prescribed on account of Rehnquist's severe, chronic lower back

402 See Steven R. Weisman, Stewart Will Quit High Court July 3; Reasons Not Given, NY Times A1 (June 19, 1981).

403 Linda Greenhouse, Stewart on His Retirement: "Better to Go Too Soon," NY Times 9 (June 20, 1981).

404 See id. See also Fred Barbash, Student Query Moved Stewart to Quit; Dear Mr. Stewart, Why Do You Stay on Court Longer Than You Need To?, Wash Post A1 (June 20,1981).

405 Greenhouse, Stewart on His Retirement, NY Times at 9 (cited in note 403).

406 Barbash, Student Query, Wash Post at Al (cited in note 404).

407 Greenhouse, Stewart on His Retirement, NY Times at 9 (cited in note 403).

408 See text accompanying note 302.

409 Greenhouse, Stewart on His Retirement, NY Times at 9 (cited in note 403).

410 Benjamin Weiser and Fred Barbash, Pain Drug Made Rehnquist Lose "Mental Clarity," Wash Post A1 (Jan 1,1982). See also Mary Thornton, Rehnquist Preparing to Leave GW Hospital, Wash Post A20 (Jan 2, 1982); Justice Rehnquist May Leave Hospital, NY Times 20 (Jan 3, 1982); Peter Perl, Rehnquist Is Released by Hospital; Justice Free of Symptoms, May Return to Work Soon, Wash Post B1 (Jan 4, 1982). 
pain." The doctor said that the "disturbances" had entailed Rehnquist "seeing things and hearing things that other people didn't see or hear."

Perhaps most serious of all, however, were the ensuing news stories detailing how Supreme Court journalists had been aware ever since the beginning of October Term 1981 three months earlier that Rehnquist was having constant difficulty in speaking from the bench. As United Press International's Court correspondent confessed in an early dispatch, Rehnquist's speech problems "have been obvious to regular observers of the Supreme Court for three months." However, "the story went unreported until this week because it was not known precisely why Rehnquist was slurring his words and having great difficulty speaking while questioning attorneys during oral arguments." Courtroom regulars had witnessed "lengthy, often embarrassing pauses as [Rehnquist] struggled to form his words," and on occasion "[t]he circumstances became so awkward that other justices sometimes jumped in to complete questions for Rehnquist."

Even the Washington Post acknowledged that "[i]n private conversation Rehnquist has displayed significant difficulty talking," "415 but following Rehnquist's speedy release from the hospital, his speech problems appeared to be completely cured by the time that he returned to the bench on January 11,1982 . $^{416}$ Four years later, when President Ronald Reagan nominated Rehnquist for promotion to Chief Justice, further details concerning what the Washington Post called Rehnquist's "drug dependency" leaked to the press within just a few hours after Senate Judiciary Committee members were given private access to Justice Rehnquist's personal medical records. ${ }^{41}$

The documents alerted Senators, and then reporters, to the fact that Capitol physician Freeman $\mathrm{H}$. Cary had retired under pressure at age fifty-nine on account of both his treatment of United States Senator John East of North Carolina, who had committed suicide in June 1986, and his record of prescribing Placidyl for Justice Rehnquist for

411 Weiser and Barbash, Pain Drug, Wash Post at A1 (cited in note 410). See also Lawrence

K. Altman, Drug Rehnquist Used Carries Strict Warning, NY Times A19 (Jan 7,1982).

412 Mr. Rehnquist's Painful Episode, Newsweek 20 (Jan 11, 1982).

413 Robert Sangeorge, Rehnquist Health Problems Went Unreported, UPI (Jan 1,1982).

414 Id.

415 Weiser and Barbash, Pain Drug, Wash Post at A1 (cited in note 410). See also Irwin Molotsky, Doctor Says Pain Drug Caused Justice Rehnquist to Slur His Speech, NY Times 9 (Jan 2, 1982).

416 See Rehnquist Back at High Court, NY Times B10 (Jan 6, 1982); Lawrence K. Altman, Justice Rehnquist Back at Work After Treatment for Drug Reaction, NY Times B15 (Jan 12, 1982); Rehnquist Back on Bench, Wash Post A6 (Jan 12,1982) (reporting that in questioning lawyers on January 11, Rehnquist "sound[ed] distinctly better and less halting").

417 Loretta Tofani, Rehnquist '81 Drug Problem Linked to Ex-Capitol Doctor, Wash Post A1 (Aug 12, 1986). 
nine years, beginning in 1972. Initially Rehnquist received 500 milligrams a day of Placidyl, which the Post emphasized was recommended for no more than two weeks maximum usage, but over the course of the ensuing nine years of prescriptions, Rehnquist's daily dosage had gradually increased to 1,500 milligrams a day by $1976 .{ }^{418}$ The next day's New York Times reported that for several years Rehnquist had been obtaining a three-month supply of the drug but using it within a onemonth period, and added that a Senate consultant, Dr. William Pollin, former director of the National Institute on Drug Abuse, had told the Judiciary Committee that Dr. Cary had informed the FBI that he had cautioned Rehnquist more than once about the strength of the dosage. ${ }^{419}$

Senate supporters of Rehnquist's promotion dismissed the issue as revealing only that Rehnquist had been "a very compliant patient," largely unasked during the brief public contretemps. First, had or had not the unusually heavy and long-term doses of such a powerful drug had any mental or emotional effects on Justice Rehnquist other than the readily observable difficulty he had in speaking come 1981 ? Second, and perhaps even more seriously, why had continuing public incoherence on the bench by an active justice of the Supreme Court not occasioned any news reports or public comment by knowledgeable journalists until Justice Rehnquist's hospitalization forced the matter into the public eye? Irrespective of the medical propriety of the treatment that was accorded Justice Rehnquist, and irrespective of what the justice himself was obligated or not obligated to make public about the state of his health, ${ }^{421}$ was not the Supreme Court press corps professionally remiss in the extreme in failing to report the undeniable public manifestation of Rehnquist's problem that it witnessed day after day during October, November, and December of 1981 ?

When Justice Rehnquist himself testified at the Senate Judiciary Committee hearings on his nomination to be Chief Justice, the Committee had agreed in advance not to ask him any public questions concerning his health. ${ }^{42}$ When Committee Chairman Strom Thurmond asked Rehnquist whether the Judicial Conduct and Disability Act of

418 See id; Richard L. Berke, Data on Rehnquist Said to Detail Increased Doses, NY Times A19 (Aug 13, 1986).

419 See Berke, Data on Rehnquist, NY Times at A19 (cited in note 418). See also Nomination of William H. Rehnquist to be Chief Justice of the United States, Executive Rep No 99-18, 99th Cong, 2d Sess 31 (Sept 8, 1986) (commenting on the independent physician's review of Justice Rehnquist's medical records).

420 Irvin Molotsky, Hatch Backs Rehnquist on Medication, NY Times D22 (Aug 14, 1986).

421 See Lawrence K. Altman, A Justice's Health: What is Private?, NY Times A20 (Jan 4, 1982).

422 See Tofani, Rehnquist's '81 Drug Problem, Wash Post at A1 (cited in note 417). 
1980 should be expanded to cover the Supreme Court, Rehnquist all but explicitly said "no." "[I]f you are talking about even a judicial council determining that one of the nine members of the Supreme Court is unable to serve and avoiding the impeachment requirement of the Constitution, that is something I would want to take a very, very long look at." ${ }^{423}$ However, when Illinois Democratic Senator Paul Simon asked Rehnquist to address in general the subject of judicial health, Rehnquist readily admitted that "I think judges have much more of a tendency to ... 'pulling the wagons around' or something like that than people in public elective life ... because, particularly on our Court, where there are only nine seats, the health of every individual Justice is an endless subject of speculation" that at times could become "ghoulish." But Rehnquist insisted that "so long as I can perform my duties, I do not think I have any obligation to give the press a health briefing." ${ }^{, 24}$ Under the Committee's ground rules, any follow-up question asking whether performance of duties had to include coherent questioning of attorneys from the bench no doubt would have been out of bounds.

One year after William H. Rehnquist's promotion, Justice Lewis F. Powell, Jr., retired from the Court at age seventy-nine. Powell told reporters upon announcing his departure that "I believe I said some years ago that it would have been wise for the Founding Fathers to have required retirement of federal judges at a specified age, perhaps at 75., ${ }^{, 25}$ Seven years later, John C. Jeffries's impressive biography of Justice Powell frankly revealed that the people closest to Powell during his two final years on the Court believed that Powell himself should have heeded that wisdom. Powell had suffered dangerously heavy bleeding following routine surgery in December 1984, and then had faced further surgery in July 1985, at age seventy-seven. ${ }^{426}$ Powell had returned to the Court for the start of October Term 1985, but Jeffries, citing to a 1992 memo written to him by one of Powell's October Term 1985 clerks, reports that "at least two of his clerks thought he should step down" at the end of that term.

For Powell, October Term 1985 had of course climaxed with the Court's now-infamous "sodomy" ruling in Bowers v Hardwick, in which Powell had been the indecisive but nonetheless eventually deci-

\footnotetext{
423 Nomination of Justice William Hubbs Rehnquist, Hearings before the Committee on the Judiciary, United States Senate, on the Nomination of Justice William Hubbs Rehnquist to be Chief Justice of the United States, 99th Cong, 2d Sess 134 (July 29-31 and Aug 1, 1986). 424 Id at 206.

425 Glen Elsasser and Janet Cawley, Powell Quits Supreme Court:Jurist, 79, Cast the Pivotal Vote in Key Decisions, Chi Trib 1 (June 27,1987).

426 See Jeffries, Justice Lewis F. Powell, Jr. at 538-40 (cited in note 288).

427 Id at 544.
} 
sive fifth vote for Justice Byron R. White's explicitly homophobic majority opinion. ${ }^{428}$ Biographer Jeffries, comparing Powell's well-known, relatively successful, and quite decisive individual opinion in Regents of the University of California v Bakke $e^{429}$ with Powell's failure to author a similarly cogent and independent individual opinion in Bowers, concluded that Powell

did not follow through. In the end, he gave up on himself and his own perspective. Age and health played their part, as Powell was now seventy-eight years old and still recuperating from a major illness the year before. Infirmity made it more difficult to summon the sustained mental energy required to translate Powell's uncertain views into law.

Jeffries's judgment was blunt but fair. "In short, Powell failed. He failed to capture the Court and make himself decisive, as he had in Bakke. More fundamentally, he failed to act on his own best judgment .... He failed ... because he did not bring his own wisdom and reflection to bear on the problem." ${ }^{431}$ Powell failed to bring that wisdom to bear because his "mental energy" was indeed in decline. Twelve months later, at the conclusion of October Term 1986 in June 1987, "Powell's awareness of his own diminishing strength" led him to finally make the retirement decision he should have made two full years earlier. ${ }^{432}$

Lewis Powell's mental decrepitude was far less dramatic than that of most of his predecessors who had likewise remained on the Court too long, but by 1987 the recurring nature of the problem ought to have been clear to all. Indeed, just two years later, in November 1989, Alabama Democratic Senator (and former Alabama Chief Justice) Howell Heflin introduced in Congress two closely related measures aimed at producing a constitutional amendment that would accomplish what Senator Nunn unsuccessfully had attempted to attain by statutory enactment a decade earlier. Heflin's plan in its most detailed version called for creating a federal Judicial Integrity Commission that would possess investigatory authority to examine whether "any justice

428478 US 186, 197 (1986) (Powell concurring).

429438 US 265 (1978).

430 Jeffries, Justice Lewis F. Powell, Jr. at 526 (cited in note 288).

431 Id at 527. See also Anand Agneshwar, Powell Concedes Error in Key Privacy Ruling: Vote to Sustain Sodomy Law at High Court Called "Mistake," NY L J 1 (Oct 26, 1990); Ruth Marcus, Powell Regrets Backing Sodomy Law, Wash Post A3 (Oct 26, 1990); David J. Garrow, Liberty and Sexuality: The Right to Privacy and the Making of Roe v. Wade 660-61,667 (Macmillan 1994) (all reporting how Powell in October 1990 had volunteered that "I think I probably made a mistake" in voting as he had in Bowers).

432 Jeffries, Lewis F. Powell, Jr. at 543 (cited in note 288). See also id at 541, 544. 
or judge ... is physically or mentally unable to perform his duties." ${ }^{433}$ If the Commission so charged, a seven-member "Court of the Judiciary" could with six affirmative votes remove a justice or judge from office or with just four votes suspend or assign to senior status a jurist "who is physically or mentally unable to perform the duties of his office." A Senate Judiciary subcommittee conducted one day of seemingly pro forma hearings on Heflin's proposal in March 1990, but no further congressional consideration or action ensued. ${ }^{435}$

\section{THE SUPREME COURT IN THE 1990S}

Senator Heflin's effort notwithstanding, the Supreme Court's problems with judicial decrepitude unsurprisingly continued right into the 1990s. In July 1990, eighty-four-year-old senior Associate Justice William J. Brennan, Jr., retired from the Court following a term during which one biographer later reported that Brennan, like his eighty-oneyear-old colleague Thurgood Marshall, had "on more than one occasion dozed off during oral arguments."

433 S J Res 232 and 233, 101st Cong, 1st Sess, in 135 Cong Rec S 31452 (Nov 21, 1989).

434 Id. S J Res 232 was the more specific of the two alternate versions; S J Res 233 proposed enactment of an amendment that simply would have declared that "Congress shail have the power to provide practices and procedures for the removal from office and to provide lesser sanctions for justices, judges and other federal judicial officers found to be guilty of misconduct in office, failure to perform the duties of office, [or] inability to physically or mentally perform the duties of office." See also Michael J. Gerhardt, The Federal Impeachment Process: $A$ Constitutional and Historical Analysis 169-70 (Princeton 1996); Ross, 35 Vill L Rev at 1119-22 (cited in note 397).

Two years earlier Heflin had proposed a separate constitutional amendment to ease the process of judicial impeachment. See S J Res 113,100th Cong, 1st Sess, in 133 Cong Rec S 8761, 8763 (Apr 9, 1987); Howell T. Heflin, The Impeachment Process: Modernizing an Archaic System, 71 Judicature 123,124-25 (1987). See also Linda Greenhouse, Judge Impeachment Process Assailed, NY Times 1 (Oct 11, 1986); David Lauter, Will Claiborne's Impeachment Spur Overhaul of Process?, Natl L J 8 (Oct 20, 1986); Howell Heflin, In Wake of Claiborne Trial: Who Should Judge the Judges?, Legal Times 13 (Dec 15, 1986); Terence Moran, Capitol Hill Round-up: Gorton Still Paying for Traded Manion Vote, Legal Times 2 (Feb 16, 1987); Linda Greenhouse, Judicial Impeachment: Is Process Antiquated?, NY Times A22 (May 11, 1988); Philip D. Oliver, Systematic Justice: A Proposed Constitutional Amendment to Establish Fixed, Staggered Terms for Members of the United States Supreme Court, 47 Ohio St L J 799, 800-01 (1986) (advocating an eighteenyear maximum term of service); Doug Bandow, End Life Tenure for Judges, NY Times 27 (Sept 6, 1986) (advocating ten-year terms of service subject to senatorial reconfirmation); Macklin Fleming, Is Life Tenure on the Supreme Court Good for the Country?, 70 Judicature 322, 322 (1987) (proposing a sixteen-year maximum term of service). But see Ross, 35 Vill L Rev at 1080-92 (criticizing the Oliver and Macklin proposals).

435 See Impeachment of Article III Judges, Hearing before the Subcommittee on the Constitution of the Senate Committee on the Judiciary, 101st Cong, 2d Sess 16, 19 (Mar 21, 1990). See also Removing Judges, Wash Post A21 (Mar 22, 1990).

436 Hunter R. Clark, Justice Brennan: The Great Conciliator 273 (Birch Lane 1995). See also Jim Mann, Court Was Brennan's Life and He Gave It His Last Energy, LA Times A17 (July 21, 1990) (reporting that during an April 1990 interview, Brennan's "voice was low and weak" and he "was quite evidently failing"). 
But far and away the Court's most serious problem with decrepitude during the early 1990s involved Justice Thurgood Marshall. Even well before the 1990s, reports circulated privately that Marshall in chambers "spent hours each day telling stories and watching daytime television. He told his clerks precisely and emphatically what to do, then let them do it." ${ }^{437}$ Close observers thought that Marshall often simply chose to follow Justice Brennan's lead, and to participants inside the Court, Marshall "often seemed uninformed and disengaged." ${ }^{438}$ By the late 1980s, John Jeffries has noted, "Marshall's dependence on his senior colleague became more apparent as he lost his hearing. ${ }^{, 439}$ Citing to an interview with Justice Harry A. Blackmun, Jeffries reports that during conferences, Marshall "would lean over to Blackmun, who sat next to him at conference, and ask, 'Harry, how did Brennan vote?' If told that Brennan had voted to affirm, Marshall would say simply, 'Chief, I vote to affirm.",400

By early 1989, Marshall's image as a disengaged justice who was overly dependent upon his clerks became front-page fodder for unfriendly political commentators. ${ }^{411}$ Then, six months later, Marshall's performance on the bench during an oral argument in October of 1989 brought the problem out of the realm of rumor and placed it on full public display. On October 30, the Court heard argument in Federal Trade Commission v Superior Court Trial Lawyers Association, ${ }^{4 / 2}$ concerning whether a boycott by Washington, D.C., criminal defense attorneys wanting higher fees for representing indigent defendants violated the Sherman Antitrust Act. Some minutes into the second argument in the case, Marshall asked Willard K. Tom, who was representing the respondents, "Who is in competition with the Court?" Tom was understandably puzzled. "There is no one in competition with the Court, Your Honor." Marshall responded, "Who is in competition with the lawyers?" Tom again was puzzled. "The-there is no

437 Jeffries, Justice Lewis F. Powell, Jr. at 260 (cited in note 288).

438 Id.

439 Id.

440 Id at 260,615 . See also Harry A. Blackmun luncheon conversation with David J. Garrow (June 12,1996), Washington, D.C. (Justice Blackmun relating a similar account of Justice Marshall's behavior in conference.).

441 See Terry Eastland, While Justice Sleeps, Natl Rev cover, 24, 26 (Apr 21, 1989) (citing such overdependence as grounds for a constitutional amendment mandating retirement at either age seventy-five or age eighty); W. John Moore, Slow Change, Natl J 1086 (Apr 29, 1989) (suggesting "a mandatory retirement age of 80 for future Justices"). But see Mark Tushnet, Thurgood Marshall and the Brethren, 80 Georgetown L J 2109, 2126 (1992) (dismissing such criticism of Marshall as "wrong and perhaps racist").

442493 US 411 (1990).

443 Transcript of Oral Argument, Federal Trade Commission v Superior Court Trial Lawyers Association, No 88-1198, ${ }^{*} 27$ (Oct 30,1989) (available in Lexis-Nexis Trans File at 1989 US Trans Lexis 88). 
one in competition with the lawyers, except in the sense-_"Marshall interrupted, and his comment betrayed his problem. "Well, don't we have somebody to be in competition, to get you involved?" "44

Marshall erroneously thought Tom represented the government, not the trial lawyers. Tom tried to parry. "That-there are-I-I'm sorry, I didn't hear the last part of the question." nately made his error even clearer. "Don't we have to have somebody in competition with somebody in order to get you involved?" again tried to deflect Marshall's mistake. "In order to get the antitrust laws involved?" "Yes," Marshall said. Now it seemed that Tom had a way out: "That is correct, Your Honor. The FTC-" But Marshall interrupted. "Well, now, tell me-tell me who is in competition with who, that gives you a standing?" Tom still sought to deflect Marshall's error. "The FTC's position is that all of the CJA [Criminal Justice Act] lawyers were in competition with each other in the sense that they could decide or not decide to offer their services."

Marshall was now hopelessly lost. "The group that raises the competition point is all in competition with itself? If I appear confused, I am." Laughter rippled through the courtroom, and Tom again tried to avert Marshall's error. "Your Honor, I am sorry, I don't entirely understand the import of your question. I think our position-" But then Marshall interrupted and explicitly betrayed his misunderstanding. "Well, isn't competition necessary for you, the antitrust division-" Another justice immediately intervened-"Well, you're for the lawyers -" and Tom put the argument back on track. "I am representing the lawyers, Your Honor, the-people who went on strike in this case." Marshall tried to recover, but it was far too late. "Well, you can give me-there is no bar to you giving me some help," and the courtroom laughed again, this time in relief ${ }^{48}$

Journalist Tony Mauro described the embarrassing scene in the next issue of Legal Times." When Marshall had initially inquired about "competition," Mauro explained, "At first it seemed like a sympathetic, softball question that enabled Tom to emphasize that the lawyers were not competing against each other." But when Marshall asked his question that included "in order to get you involved ... [i]t quickly became apparent that even though Tom was well into his argument, Marshall mistakenly thought that Tom was arguing on behalf of the Justice Department's Antitrust Division against the boycott,

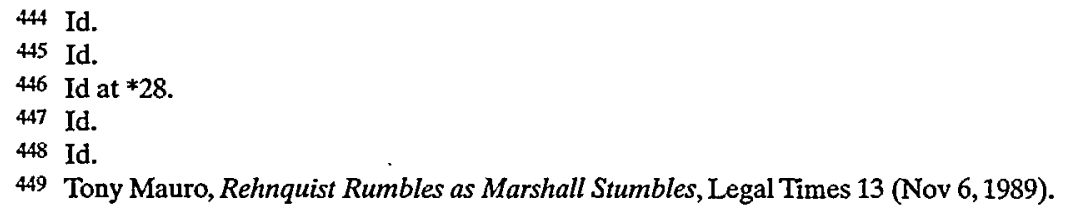


when in fact, Tom was arguing for the lawyers in favor of the boycott. The Antitrust Division wasn't even named in the case."

Mauro added that "[i]t was a painfully awkward moment. Several justices grimaced momentarily," and then one of them quickly interjected the saving correction. Mauro noted that, "[t]o his credit, Marshall recouped quickly" with his remark about "giving me some help," "sis but the damage had been done, and even months later news stories concerning Marshall continued to recount what had happened. $^{452}$

A somewhat similar courtroom scene occurred less than six weeks later when it came Marshall's turn to announce the decision of the Court in United States $v$ Goodyear Tire and Rubber Co." "When called on to read a few lines from an opinion being issued in his name," Los Angeles Times correspondent David G. Savage wrote, the way in which Marshall "stumbled over the words" produced "embarrassed looks in the courtroom." tempts did Marshall succeed in articulating the word "subsidiary.",5s

When Justice William J. Brennan, Jr., retired from the Court in July of 1990, and President Bush nominated United States Circuit Judge David H. Souter of New Hampshire to succeed him, Justice Marshall created a national controversy by attacking President Bush and criticizing the Souter nomination in a videotaped television interview with ABC News correspondent Sam Donaldson. ${ }^{456}$ Acknowledging that "I was listening to television" when the nomination was announced, Marshall told Donaldson that he had telephoned his wife to ask, "Have I ever heard of this man?" The answer was a decisive "no." Marshall declared that he looked forward to voting against Bush's re-election, and at the end of the segment even Donaldson acknowledged that some viewers would conclude from Marshall's performance that "he's lost it." New Hampshire Republican Senator

$450 \mathrm{Id}$.

451 Id.

452 See David G. Savage, High Court's Conservative New Guard Steers Debate, LA Times A1, A30 (Apr 1, 1990); James H. Rubin, Supreme Court's Marshall Plans to Outlive the Opposition, LA Times A11 (June 3, 1990).

453493 US 132 (1989).

454 Savage, High Court's Conservative New Guard, LA Times at A30 (cited in note 452). See also David G. Savage, Turning Right: The Making of the Rehnquist Supreme Court 78 (Wiley 1992).

455 Savage, High Court's Conservative New Guard, LA Times at A30 (cited in note 452).

456 See ABC News, Primetime Live (July 26, 1990) (available in Lexis-Nexis News Library, Trans File).

457 Id at 3. Marshall also told Donaldson that "I have a deal with my wife that when I begin to show any signs of senility, she'll tell me. If I get feeble or anything like that, and get a little weesely [sic], she'll know." Id at 6.

458 Id at 5,6 . 
Warren Rudman said that "[l]ast night was sad" when asked to comment on Marshall's interview, ${ }^{459}$ and on a weekend news show, journalist (and future Undersecretary of State) Strobe Talbott termed Marshall's conduct "downright embarrassing" and added that Marshall was "losing his judiciousness, if not more." As Marshall's biographer, Juan Williams, later acknowledged, previous questions about Marshall's "physical health now extended to questions about his mental health."

Justice Marshall remained on the bench when October Term 1990 commenced, and in late November the Court granted certiorari to a Missouri case in which state court judges had so far unsuccessfully challenged a state constitutional provision mandating judicial retirement at age seventy. ${ }^{462}$ Journalists noted that four of the justices were themselves past their seventieth birthdays (Marshall and Blackmun were both eighty-two years old, Byron $R$. White was seventy-three, and John Paul Stevens was almost seventy-one), ${ }^{4 \times 3}$ but when oral argument in the case took place in mid-March of 1991, the issue of judicial decrepitude was hardly touched upon. ${ }^{44}$ In late June, the Court upheld the constitutionality of the Missouri provision by a vote of seven to two with only the two oldest justices, Marshall and Blackmun, in dissent. Justice Sandra Day O'Connor's majority opinion forcefully declared that

[t]he people of Missouri have a legitimate, indeed compelling, interest in maintaining a judiciary fully capable of performing the demanding tasks that judges must perform. It is an unfortunate fact of life that physical and mental capacity sometimes diminish with age. The people may therefore wish to replace some older judges. Voluntary retirement will not always be sufficient. Nor may impeachment-with its public humiliation and elaborate

459 Adam Pertman, Thornburgh "Saddened" by Criticism of Souter, Boston Globe 1 (July 28, 1990).

460 Federal News Service, Inside Washington 3 (July 28, 1990). See also Linda Greenhouse, Hot Words of a Justice Are Hardly a Surprise, NY Times A8 (July 30,1990) (acknowledging that in the wake of the interview, "[p]eople wondered openly about the 82-year-old Justice's own mental competence" but claiming that "his mind is still sharp").

461 Juan Williams, Thurgood Marshall: American Revolutionary 390 (Times 1998).

462 Gregory v Ashcroft, 498 US 979 (1990).

463 See Linda Greenhouse, Justices to Hear Appeal in Retirement Age Case, NY Times B8 (Nov 27, 1990); Linda Greenhouse, Elderly Justices Facing an Issue Close to Home, NY Times B12 (Dec 13, 1990).

464 See Transcript of Oral Argument, Gregory v Ashcroft, No 90-50 (Mar 18, 1991) (available in Lexis-Nexis Trans File at 1991 US Trans Lexis 179). See also Tony Mauro, Show Me, Again: Missouri Back for More, Legal Times 10 (Mar 25, 1991). 
procedural machinery-serve acceptably the goal of a fully functioning judiciary. ${ }^{455}$

The Court also found no flaw in Missouri's unwillingness to impose mandatory retirement upon other elected state officials, "whose performance is subject to greater public scrutiny." deterioration in performance is more readily discernible" than in a judicial branch characterized by “[j] udges' general lack of accountability." ${ }^{47}$

Eight days after that decision in Gregory v Ashcroft, Thurgood Marshall finally announced his retirement from the Court. That news prompted one columnist to call for a constitutional amendment authorizing Congress to set a mandatory retirement age so as to "preserve the independence of the federal judiciary while protecting the nation from the danger of senile justices casting votes. ${ }^{408}$ But the issue of Marshall's mental capacity during his later years on the Court outlived the justice himself. When Marshall's Supreme Court case files became available for research following Marshall's death in early 1993, perhaps the only potentially embarrassing revelation to emerge from amongst a host of early articles ${ }^{499}$ involved the possibility that Marshall had not known what he was doing when, in a February 1991 conference, he had cast his first and only vote in favor of upholding the imposition of the death penalty upon a criminal defendant, Bryan Lankford. ${ }^{470}$

The first writer to plumb the question, New Republic legal affairs editor Jeffrey Rosen, cited Marshall's "disengagement" but did not contend that the conference vote had been unknowingly cast. ${ }^{\text {th1 }}$ Instead, Rosen noted how one of Marshall's clerks, Sheryll D. Cashin, had written the justice "an impassioned memo" in response to his vote, and how Marshall had then notified the Chief Justice that he was switching sides. ${ }^{4 / 2}$ Rosen concluded that "the justice changing his vote does not appear to have grappled with the constitutional issues the

465 Gregory v Ashcrofi, 501 US 452, 472 (1991) (internal citation omitted). See also Marcus, State Age Limits for Judges Upheld, Wash Post at A10 (cited in note 358); Hatten $v$ Rains, 854 F2d 687,689 (5th Cir 1988) (Goldberg) (stating that "I write today, at 82 years of age, with a heavy pen and an even heavier heart" in upholding mandatory judicial retirement at age seventy-five for Texas state judges).

466 Gregory, 501 US at 473.

467 Id. 1991).

468 Stephen Chapman, Octogenarian Justices Are No Asset to the Court, Chi Trib 13 (July 4,

469 See David J. Garrow, There's Nothing to Fear in Those Papers, Wash Post 25 (May 27, 1993).

470 See Lankford $v$ Idaho, 500 US 110 (1991).

471 See Jeffrey Rosen, Court Marshall, New Republic 14-15 (June 21, 1993).

472 Id. 
case presents." ${ }^{4 / 3}$ Several years later, however, one of Marshall's former clerks, Mark Tushnet, offered a decidedly more sympathetic analysis. "When the justices discussed the case," in which the trial judge had imposed the death penalty even though the prosecutor had not requested it and it had not been discussed at the sentencing hearing, "Marshall voted to affirm the Idaho Supreme Court. He did not want to bail the defense lawyer out of a bad situation. As he initially saw it, the legal issue was whether the defense had enough notice that a death sentence was possible.",

Tushnet's interpretation is not on its face completely convincing, especially since Marshall was the decisive fifth vote in favor of upholding Lankford's sentence. ${ }^{4 / 5}$ But when Edward Lazarus, a former clerk to Justice Blackmun, reviewed Marshall's file on Lankford in light of his own High Court experience during October Term 1988, he reached a radically different conclusion. "In truth," Lazarus wrote:

[by 1990] Marshall was no longer up to his responsibilities, or even the appearance of being up to them. Without Brennan's lead to follow he made mistakes, some embarrassing. In one argued capital case, Lankford v. Idaho, Marshall became so confused that, for the first time in his career, he voted at conference to uphold a defendant's death sentence. Worse yet, the error gave the conservatives a 5-4 majority. Marshall's clerk, in a tactful though slightly panicked memo, had to point out her boss's obvious blunder. Then Marshall had to write his colleagues to recant. $^{\text {sic }}$

The Marshall Papers' full documentary record concerning Lankford $v$ Idaho suggests that Jeffrey Rosen's judgment may be more appropriate than either Tushnet's or certainly Lazarus's interpretations. Lankford's death sentence, just like the capital penalty imposed upon his brother for the same murder, ${ }^{m}$ had come before the Court previously but had been remanded to the Idaho Supreme Court for reconsideration. ${ }^{4 \pi}$ After the Idaho Court had again affirmed Lankford's sentence, ${ }^{477}$ the Supreme Court had entered a stay, ${ }^{400}$ and,

473 Id.

474 Mark V. Tushnet, Making Constitutional Law: Thurgood Marshall and the Supreme Court, 1961-1991 190 (Oxford 1997).

475 See id.

476 Edward P. Lazarus, Closed Chambers: The First Eyewitness Account of the Epic Struggles Inside the Supreme Court 446-47 (Times 1998).

477 See Lankford $v$ Idaho, 497 US 1032, 1032 (1990) (denying certiorari). As was their regular practice, both Justices Marshall and Brennan dissented from denial, stating that they would "vacate the death sentence[ ] in this case." Id.

478 See Lankford $v$ Idaho, 486 US 1051 (1988).

479 See State v Lankford, 116 Idaho 279,775 P2d 593 (1989).

480 See Lankford v Idaho, 490 US 1061 (1989). 
seventeen months later, granted certiorari when the Court failed by a margin of just one to muster the six votes necessary for summary reversal. ${ }^{421}$ Oral argument took place on February 19, 1991, and in advance of it, Sheryll Cashin had prepared a detailed bench memorandum noting that Lankford's claim of ineffective assistance by his original trial counsel had not been preserved upon appeal but nonetheless arguing strongly in favor of reversal because of the alleged lack of notice to Lankford's second attorney at the sentencing hearing. ${ }^{422}$ At argument Justice Marshall bluntly asked Idaho's Attorney General, Larry EchoHawk, whether it was fair for the trial judge not to reveal at that hearing that he was indeed considering the death penalty. "Yes or no?" Marshall demanded. "I believe that it is," EchoHawk answered. ${ }^{433}$

Two days later, and one day before the justices would discuss and vote on Lankford at their weekly Friday conference, Cashin gave Marshall another memorandum reporting that while Marshall had cast at least 2,212 votes against death sentences over the previous nineteen years, "I could not find a single case in which you joined a majority opinion that disposed of the case in a manner adverse to the capital [defendant]." ${ }^{444}$ Clearly indicating her awareness that Marshall already was now inclined to vote to affirm rather than reverse Lankford's sentence, Cashin noted that "Lankford appears to be the first case in which your view of the capital [defendant's] substantive arguments is at odds with your standard view that the death penalty violates the Eighth Amendment in all circumstances." ${ }^{\text {,45 }}$ Marshall obviously had told Cashin that he saw no lack of notice due process violation growing out of the trial judge's conduct, and Cashin hence was fervently attempting to convince Marshall that his otherwise unalterable opposition to the death penalty necessarily had to trump his stance on the due process claim.

481 See Lankford v Idaho, 498 US 919 (1990). See also John Paul Stevens, Memorandum to the Conference, Re: 88-7247-Lankford v. Idaho (Sept 19, 1990), in Thurgood Marshall Papers, Box 537, Folder 7 (Manuscript Division, Library of Congress) (stating that following the October Term 1989 stay, five justices, including Marshall, had voted for summary reversal); Thurgood Marshall to John Paul Stevens, Re: No. 88-7247-Lankford v. Idaho (Oct 11, 1990), in Thurgood Marshall Papers, Box 537, Folder 7 ("Dear John: I am still with you."); Tushnet, Making Constitutional Law at 190 (cited in note 474); DC [Debra Cohn], Capital Case, 88-7247 (July 28, 1989), in Thurgood Marshall Papers, Box 494, Folder 4 (cert memo).

482 SC [Sheryll D. Cashin], Bench Memorandum (Feb 19, 1991), 5-7, in Thurgood Marshall Papers, Box 513, Folder 7 (Manuscript Division, Library of Congress).

483 Transcript of Oral Argument, Lankford v. Idaho, No 88-7247, *1, *18-19 (Feb 19, 1991) (available in Lexis-Nexis Trans File at 1991 US Trans Lexis 149); Carol Bradley, Supreme Court Hears Idaho Case, Gannett News Service (Feb 19,1991).

484 Sheryll Cashin to Justice Marshall, Capital Case, Feb 21, [1991], in Thurgood Marshall

Papers, Box 537, Folder 7 (Manuscript Division, Library of Congress).

485 Id at 2

486 Id at 2-3. 
Nonetheless, when Lankford was discussed at the justices' Friday conference, Marshall explicitly and without hesitation joined Chief Justice Rehnquist and Justices White, Scalia, and Souter in voting to uphold Lankford's death sentence. ${ }^{47}$ Either just before or, more likely, just after that conference, Cashin gave Marshall yet another memo emphasizing that

[by] voting to affirm in this case, you are providing the fifth vote to uphold a death sentence. It seems to me, to be consistent with your established position that the death sentence is cruel and unusual in all circumstances, your posture should not be to affirm but to reverse or vacate .... In this way you could remain consistent with your longstanding position on the death penalty without sanctioning the [supposed] bad lawyering that so troubled you in this case.

Cashin concluded by saying, "Please let me know if you would like to discuss this further.",\$\$

Ten days later, on March 4, 1991, Chief Justice Rehnquist officially assigned authorship of the five-to-four majority opinion in Lankford v Idaho to Thurgood Marshall. ${ }^{40}$ The Marshall Papers are silent as to whether or not the Justice had accepted Sheryll Cashin's invitation that they discuss the case further, but on March 5 Marshall wrote to Chief Justice Rehnquist to say that "I am sorry but I must ask you to reassign Lankford $v$. Idaho. The question presented," Marshall said, quoting from how Cashin had characterized the issue in one of her earlier memos, "is "whether a death sentence violates the Sixth, Eighth and Fourteenth Amendments' (emphasis added)." ${ }^{\text {"491 }}$ Marshall added that "I cannot bring myself to endorse the death penalty under the Eighth Amendment.."12 Two months later, in a five-to-four majority opinion authored by Justice John Paul Stevens, and joined by Thurgood Marshall, the Supreme Court reversed Lankford's death sentence and again remanded the case to the Idaho Supreme Court. ${ }^{439}$

487 See Docket Sheet, 88-7247-Lankford v Idaho, in Thurgood Marshall Papers, Box 556, Folder 6 (Manuscript Division, Library of Congress) (Marshall noting in his own handwriting, "TM Affirm").

488 Sheryll Cashin to Justice Marshall, Capital Case - Lankford v Idaho, Feb 22, [1991], in Thurgood Marshall Papers, Box 537, Folder 7 (Manuscript Division, Library of Congress).

489 Id.

490 See Docket Sheet, 88-7247-Lankford $y$ Idaho (cited in note 487).

491 Justice Marshall to Chief Justice Rehnquist, Re: 88-7247-Lankford v Idaho, Mar 5, 1991, in Thurgood Marshall Papers, Box 537, Folder 7 (Manuscript Division, Library of Congress). See also Cashin to Marshall at 2 (cited in note 484).

492 Marshall to Rehnquist, Re: 88-7247 at 1 (cited in note 491 ).

493 See Lankford $v$ Idaho, 500 US 110 (1991). Justice Stevens wrote that the sentencing judge's "silence" concerning the death penalty "had the practical effect of concealing from the parties the principal issue to be decided at the hearing. Notice of issues to be resolved by the ad- 
The documentary record thus shows that Edward Lazarus's summary characterization ${ }^{44 t}$ of Marshall's conference vote in Lankford is both unfair and inaccurate, but a rejection of Lazarus's erroneous description does not therefore mean that Marshall's behavior in Lankford thus reflected at least minimally adequate judicial acuity. As Jeffrey Rosen quite rightly pointed out well before either Tushnet or Lazarus addressed themselves to the subject, Marshall's inability and/or unwillingness to acknowledge, prior to March 5, that his stance in Lankford $v$ Idaho was, as Sheryll Cashin correctly kept insisting, profoundly and unquestionably self-contradictory, reflected such a lack or deterioration of analytical reasoning ability as to undeniably demonstrate that by 1991 Thurgood Marshall should no longer have been casting life or death votes as a Justice of the United States Supreme Court. $^{495}$

\section{CONCLUSION}

David Atkinson concludes Leaving the Bench with the reassuring assertion that "there have been no recent instances of justices clinging to their seats for years after falling into decrepitude." upon how inclusive a reach one attributes to the word "recent," Atkinson's invocation of "years," if read literally, may shield him from rebuttals that cite William O. Douglas or even Lewis F. Powell, Jr., but it certainly fails to take into account even Atkinson's own forthright acknowledgement that "Justice Marshall was clearly unable to function satisfactorily in his last years." Atkinson likewise asserts that "it is virtually impossible to completely conceal physical or mental decrepitude within the Court at the present time" "the danger of extended service on the part of a decrepit justice is today less than in the earlier periods of Court history."

versary process is a fundamental characteristic of fair procedure." Id at 126. See also State $v$ Lankford, 127 Idaho 608, 903 P2d 1305 (1995), cert denied, Idaho v Lankford, 517 US 1128 (1996).

494 See text accompanying note 476 .

495 Fortunately, Justice Marshall announced his retirement from the Court on June 27, 1991, at the end of October Term 1990. See Andrew Rosenthal, Marshall Retires From High Court; Blow to Liberals, NY Times A1 (June 28, 1991). See also Atkinson, Leaving the Bench at 5-6 (cited in note 1) (observing, with reference to Justice Marshall's press conference on June 28, 1991, that the fact that Marshall "had stayed too long was shockingly apparent"). See also Neil A. Lewis, Marshall Urges Bush to Pick "the Best," NY Times 8 (June 29,1991).

496 Atkinson, Leaving the Bench at 167 (cited in note 1).

497 Id at 179.

498 Id at 168. See also Ross, 35 Vill L Rev at 1088 (cited in note 397) (contending that "[s]evere infirmities today are unlikely to escape the bright light of publicity increasingly cast upon the Court").

499 Atkinson, Leaving the Bench at 169 (cited in note 1). 
Such comforting claims, however, are contradicted both by the scandalously tardy press coverage of then-Justice Rehnquist's publicly slurred speech during October Term 1981 - which Atkinson himself again readily acknowledges ${ }^{\mathrm{s}(0)}$-and by journalists' seriously substandard reporting concerning Justice Marshall. Shortly before Marshall's 1991 retirement, one reporter admitted in an anonymous interview that Marshall's decrepitude was "[a] story that should have been written but hasn't by me or anyone else." ${ }^{\text {sol }}$ The journalist acknowledged that Marshall often "seems unprepared in oral arguments" and admitted that "there is a legitimate question that somebody like him ought to retire. The story hasn't been written," and "one reason it hasn't been written is that he is the first black justice." ${ }^{, 52}$ But in an attempt to justify journalistic passivity, the reporter wondered, "What would you accomplish by writing about him being a doting, noncontributing member? It's not as if he is the secretary of defense and handling the nuclear button." ${ }^{5 / 3}$ Justice Marshall of course controlled no nuclear weapons, but in Lankford $v$ Idaho his ability or inability to cast his vote with adequate analytical competence had indeed decided a literal question of life or death.

David Atkinson readily acknowledges that since 1954, "the average age for retirement or resignation has increased to seventy-seven, the highest in the Court's history. Justices are living longer, but their disinclination to leave has remained unchanged" "or has indeed increased. Nonetheless, Atkinson insists that remunerative pensions, informal collegial pressures, and media attentiveness "are sufficient safeguards against extended disability." far-from-complete plumbing of the historical record, Atkinson declares that "[p]rocedures that have worked tolerably well for over two centuries should not be casually set aside in the absence of an overwhelming case for change," which he claims "does not now exist.", Instead, Atkinson says, all that needs to be done is for the Supreme Court to be more publicly forthcoming about the justices' health, for the justices to become less reliant upon their law clerks, and for jus-

500 See id at 164.

501 Richard Davis, Decisions and Images: The Supreme Court and the Press 127 (Prentice Hall 1994).

502 Id.

503 Id. See also Randall Kennedy, Cast a Cautious Eye on the Supreme Court, 12 Media Stud J 112,120 (1998) (observing that "reporters who cover the Supreme Court continue to adopt a role more befitting of publicists than journalists").

504 Atkinson, Leaving the Bench at 138 (cited in note 1).

s05 Id at 174 .

506 Id at 175. 
tices to retire "while still in good health, usually by their midseventies." "son

Atkinson states that this last proposal "should become an informal institutional tradition," and then claims that "to a degree it already has"so - somehow overlooking the recent cases of Justice Marshall, Justice Brennan, and Justice Powell, in addition to octogenarian Justices Blackmun and Stevens. Atkinson correctly notes that any "disability prior to an agreed-upon retirement age would not be affected by a mandatory retirement age, ${ }^{, 5 \infty}$ but he conveniently fails to note that all four cases of mental decrepitude which have weakened the Court within the past thirty years - Justices Black, Douglas, Powell, and Marshall-involved justices older than age seventy-five.

David Atkinson's failure to seriously and accurately weigh the case for constitutional reform may not be surprising in light of Leaving the Bench's deficient rendering of the relevant history, ${ }^{\text {sto }}$ but Atkinson is far from the only writer who has allowed a Pollyannaish attitude to obscure a clear view of the historical record. Just one year after Justice Douglas's ignominiously tardy departure from the Court, an unsigned comment in the Yale Law Journal asserted that "the frequency of disability on the Court is declining.", Dismissing Douglas and overlooking the already well documented case of Justice McKenna, ${ }^{\text {s12 }}$ the Yale author claimed that "[o]f the Justices appointed this century, only William Moody remained on the Court after his disability became evident." lingered on the Court," in part because "the Court appears to have developed an informal procedure whereby the other Justices suggest retirement to a Justice whose health or capabilities are failing.. ${ }^{.514}$

Insisting that the historical record thus indicated that "the actual harm from judicial disability is slight,",sis the Yale author concluded that "[ $t]$ he Framers were willing to accept the inconvenience of disability, and there is no convincing evidence that their choice was in-

\footnotetext{
507 Id at $178-79$.

508 Id at 179.

509 Id at 174 .

510 But see Recent Publications, 113 Harv L Rev 834, 834 (2000) (asserting that Leaving the Bench is both "comprehensive" as well as "engaging").

511 Note, 85 Yale L J at 719 (cited in note 368).

512 See text accompanying notes 83-98. In 1976, revelatory accounts concerning Justices Black, Whittaker, Minton, and Murphy had not yet appeared.

513 Note, 85 Yale L J at 720 (cited in note 368 ).

514 Id. See also Ross, 35 Vill L Rev at 1088 (cited in note 397) (asserting that "there is no evidence that incapacitated Justices have in recent years served on the Court for any substantial period of time").

515 Note, 85 Yale L J at 720 (cited in note 368). See also Ross, 35 Vill L Rev at 1088 (cited in note 397 ) (contending that "[t]he Court is unlikely to suffer any great harm if incapacitated members serve for short periods of time").
} 
correct." ${ }^{516}$ That invocation of the Framers was pegged to a passage in the Federalist 79, where Alexander Hamilton had argued against any constitutional provision setting a judicial mandatory retirement age. Hamilton had also appeared to say that judicial "insanity," as distinct from mere "inability," was grounds for impeachment, ${ }^{518}$ but Hamilton's opposition to compulsory retirement, grounded in his eyes in 1788 on the absence of any judicial pensions, ${ }^{\text {s19 }}$ possesses little relevance and even less persuasiveness two centuries later. ${ }^{520}$

Much like the Yale author, United States Circuit Judge Irving R. Kaufman insisted in 1979, also in the Yale Law Journal, that when mental decrepitude occurred, "[t]he problem can almost always be managed effectively in a personal and informal manner" through the intercession of fellow justices and relatives. ${ }^{521}$ Judge Kaufman cited the

516 Note, 85 Yale L J at 720 (cited in note 368).

517 See Federalist 79 (Hamilton), in Jacob E. Cooke, ed, The Federalist Papers 533 (Wesleyan 1961). Referring to a New York state constitutional provision that then required judicial retirement at the relatively young age of sixty, Hamilton wrote in Federalist 79:

I believe there are few at present, who do not disapprove of this provision. There is no station in relation to which it is less proper than to that of a judge. The deliberating and comparing faculties generally preserve their strength much beyond that period, in men who survive it; and when in addition to this circumstance, we consider how few there are who outlive the season of intellectual vigour, and how improbable it is that any considerable proportion of the bench, whether more or less numerous, should be in such a situation at the same time, we shall be ready to conclude that limitations of this sort have little to recommend them.

Id.

518 See id. Hamilton feared what any requirement of mental competency might generate:

An attempt to fix the boundary between the regions of ability and inability, would much oftener give scope to personal and party attachments and enmities, than advance the interests of justice, or the public good. The result, except in the case of insanity, must for the most part be arbitrary; and insanity without any formal or express provision, may be safely pronounced to be a virtual disqualification.

Id. Scholars read that final sentence to mean that judicial insanity would merit congressional impeachment. See Gerhardt, The Federal Impeachment Process at 16-17 (cited in note 434); Berger, Impeachment at 183-87 (cited in note 366); Berger, 79 Yale L J at 1529 (cited in note 366); Carpenter, Judicial Tenure in the United States at 118 (cited in note 368 ).

519 See Federalist 79 at 533-34 (cited in note 517). Immediately following the passage quoted in note 518 , Hamilton stated:

In a republic, where fortunes are not affluent, and pensions not expedient, the dismission of men from stations in which they have served their country long and usefully, on which they depend for subsistence, and from which it will be too late to resort to any other occupation for a livelihood, ought to have some better apology to humanity, than is to be found in the imaginary danger of a superannuated bench.

Id.

520 See Kramer and Barron, 35 Geo Wash L Rev at 469 (cited in note 367) (stating that "too much store should not be placed on what Hamilton said so long ago"); Henry Paul Monaghan, The Confirmation Process: Law or Politics?, 101 Harv L Rev 1202, 1211 (1988) (terming Hamilton's reasoning "unpersuasive" and observing that "[g]iven the current prevalence of pensions ... Hamilton's argument no longer carries weight").

521 Kaufman, 88 Yale L J at 709 (cited in note 368). 
cases of Justices Grier, Field, McKenna, and Holmes as support for his contention that "[a]lmost invariably" the decrepit justice "will acquiesce," and added that "[e]ven if the judge is slow to accept the suggestion of his brethren, this method is sure to accomplish his ouster faster than a formal procedure.",523

Judge Kaufman blithely dismissed what he called "largely imagined fears of mental or physical incapacity, ${ }^{, 524}$ and his wishful optimism was eagerly seconded in no less a publication than the Harvard Law Review. Conservative commentator and former Reagan Administration Justice Department official Bruce Fein, arguing against any new limitations upon judicial life tenure, naïvely insisted that the historical record showed how time and again the Supreme Court had benefited from the ongoing service of extremely elderly justices.

Limited tenure for Justices would deny the Court the long experience and continuity that is important to institutional competence. The Supreme Court's luster would surely have been dimmed if legal giants such as Chief Justices John Marshall and Roger B. Taney or Associate Justices Stephen Field, Oliver Wendell Holmes, Jr., Louis Brandeis, Felix Frankfurter, Hugo Black, and William O. Douglas had departed after fifteen or twenty years on the Court. ${ }^{525}$

Leaving aside Marshall and Taney, both of whom remained Chief Justice until the day they died, one just a few weeks shy of age eighty and the other at age eighty-seven, the irony that four of Fein's six topranked Associate Justices-Field, Holmes, Black, and Douglascontinued to serve past the point at which their colleagues and/or their spouses believed they no longer were fully competent of course conveys exactly the opposite message from the one that Fein intended.

The history of mentally decrepit justices on the United States Supreme Court powerfully rebuts the reassuring platitudes voiced by Atkinson, Kaufman, and Fein. While the pre-twentieth-century Court featured at least four justices-Baldwin, Grier, Clifford, and Field-

522 Id.

523 Id. See also Ross, 35 Vill L Rev at 1088 (cited in note 397) (conceding that Justice Douglas "continued in office for more than ten months after a stroke greatly impaired his physical and mental powers" and acknowledging that Douglas retired "only in response to considerable pressure from friends and colleagues" but nonetheless insisting that the fact that Douglas finally did retire is "more significant than the fact that he was reluctant to").

524 Kaufman, 80 Colum L Rev at 698 (cited in note 368).

525 Bruce Fein, A Circumscribed Senate Confirmation Role, 102 Harv L Rev 672, 679-80 (1989). See also Ross, 35 Vill L Rev at 1091 (cited in note 397) (noting that "some of Justice Holmes's most significant contributions to the Court were made after he had served more than eighteen years," or subsequent to 1920 , when Holmes had turned seventy-nine, and that "[s]imilarly, Justice Black made major contributions" during his "final decade" of service, after he had turned seventy-five). 
and perhaps two more-Rutledge and Cushing-whose mental incapacity should have barred their continued service, the twentiethcentury Court has featured eleven justices whose mental decrepitude or mentally infirm judgment should have led to their departure from the bench years or months before they did vacate their seats. Prior to World War II, both Chief Justices Fuller and Taft, and Justices McKenna and Holmes, all remained on the Court longer than their colleagues and relatives knew was in the public interest. Since World War II, two Justices-Murphy and Whittaker-suffered from conditions which should have precluded their ongoing service, and five others-Minton, Black, Douglas, Powell, and Marshall-all overstayed the length of service their mental energies were capable of rendering.

In almost every such case, ${ }^{526}$ the historical record indicates that colleagues and relatives who knew that a justice was no longer functioning with adequate mental capacity were highly reluctant and in some instances willfully dilatory in explicitly telling their friend or $p a$ ter familias that his continued service was contrary to both the Court's and litigants' best interests. Likewise, the failure of the Supreme Court press corps to cover two painful but undeniably important stories from within the last twenty years - then-Justice Rehnquist's publicly visible struggle with deleterious overmedication, and Justice Marshall's equally visible difficulties in demonstrating his even minimally adequate grasp of cases that were being argued before himpowerfully disproves the contention that today's omniscient media coverage will protect the public interest even if a justice's colleagues and relatives fail to act in the Court's and country's best interest.

A constitutional amendment imposing mandatory retirement at age seventy-five would not of course spare the Supreme Court from every such burden or embarrassment. Frank Murphy was not yet sixty, and Sherman Minton and Charles Whittaker were only sixty-five, when their abilities to contribute adequately to the work of the Court came to an end, but in seven of the other eight twentieth-century instances of a mentally decrepit Justice staying too long on the Court, the Justice in question was older than seventy-five. William Howard Taft was only seventy-two when his mental powers seriously waned, but of the seven others, Melville Fuller was seventy-seven, Joseph McKenna was seventy-eight, Oliver Wendell Holmes was over ninety, Hugo Black was eight-three, William O. Douglas was seventy-six, Lewis F. Powell, Jr., was seventy-seven, and Thurgood Marshall was eighty-two.

526 Justice Minton and perhaps Justice Whittaker appear to be the only twentieth-century exceptions. 
This highly instructive twentieth-century historical record must be absorbed in tandem with the stories of the three major constitutional reform efforts that have sought to remedy this recurring problem of judicial decrepitude. Although existing scholarship has all but completely overlooked or forgotten the first two efforts, both in 1937 and again in 1954, successful constitutional reform was very much within reach.

In April or May of 1937, if only Franklin D. Roosevelt had been willing to accept the constitutional discernment and political judgment of such supporters as his own Attorney General and Columbia's Dean Smith, as well as numerous Democratic senators, he could have attained both the symbolic victory he so intensely coveted and a constitutional reform that would have stood the United States in very good stead for decades to come. Similarly, in 1954 and 1955, had the advocates of reform been able to complete their congressional efforts before the first Brown $v$ Board of Education and then the Communism cases thrust the Supreme Court into ideological hot water with a conservative-dominated Congress, a constitutional amendment compelling judicial retirement at age seventy-five might indeed have been adopted.

Senator Nunn's reform campaign of the 1970s may well have erred fatally in imagining that a new mechanism for removing disabled or decrepit justices could ever be put into place by statutory enactment rather than constitutional amendment, but Nunn's effort again highlighted what remarkably widespread support the basic policy of mandatory judicial retirement has long attracted. Whether one looks at the experienced judicial figures who have advocated itSamuel F. Miller, Henry Billings Brown, Charles Evans Hughes, Owen J. Roberts, Earl Warren, Byron R. White, and Lewis F. Powell, Jr.-or at the succession of presidents who at different times in their careers also endorsed it-William Howard Taft, John F. Kennedy, Lyndon B. Johnson, and George Bush-or at the thirty-six states that, with a hearty endorsement from the Supreme Court itself, ${ }^{527}$ impose mandatory retirement upon their own judges, the record is repeatedly clear that this is a federal constitutional reform whose time should have come.

But our history is likewise clear that no single case of mental decrepitude or public embarrassment-not William O. Douglas or Thurgood Marshall -will on its own ever bring about what such assiduous voices as Young B. Smith, Edwin A. Falk, and Sam Nunn failed to attain. History teaches us that a constitutional amendment mandating compulsory retirement at age seventy-five will strengthen the Su-

527 See Gregory v Ashcroft, 501 US 452, 463 (1991). 
preme Court of the twenty-first century and save it from predictable pain and embarrassment. However, the far more likely course is that five decades hence, some future scholar will update this article by adding another half-dozen mentally decrepit justices to the sad and poignant roster our history already offers of jurists who harmed their Court and hurt their own reputations by remaining on the bench too long. 


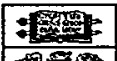

$$
\begin{aligned}
& \text { (1) }
\end{aligned}
$$

